(2) norden 



\title{
Tools for Assessing Phosphorus Loss from Nordic Agriculture
}

\author{
Edited by
}

Goswin Heckrath, Marianne Bechmann, Petri Ekholm, Faruk

Djodjic, Barbro Ulén, Hans Estrup Andersen and Preben Olsen 
Tools for Assessing Phosphorus Loss from Nordic Agriculture

TemaNord 2005:583

(C) Nordic Council of Ministers, Copenhagen 2005

ISBN 92-893-1242-4

Available as Print on Demand

This publication can be ordered on www.norden.org/order. Other Nordic publications are available at www.norden.org/publications

Printed in Denmark

Nordic Council of Ministers

Store Strandstræde 18

DK-1255 Copenhagen K

Phone (+45) 33960200

Fax (+45) 33960202

www.norden.org

\section{Nordic Council}

Store Strandstræde 18

DK-1255 Copenhagen K

Phone (+45) 33960400

Fax (+45) 33111870

\section{Nordic co-operation}

Nordic co-operation, one of the oldest and most wide-ranging regional partnerships in the world, involves Denmark, Finland, Iceland, Norway, Sweden, the Faroe Islands, Greenland and Åland. Cooperation reinforces the sense of Nordic community while respecting national differences and similarities, makes it possible to uphold Nordic interests in the world at large and promotes positive relations between neighbouring peoples.

Co-operation was formalised in 1952 when the Nordic Council was set up as a forum for parliamentarians and governments. The Helsinki Treaty of 1962 has formed the framework for Nordic partnership ever since. The Nordic Council of Ministers was set up in 1971 as the formal forum for co-operation between the governments of the Nordic countries and the political leadership of the autonomous areas, i.e. the Faroe Islands, Greenland and Åland. 


\section{Content}

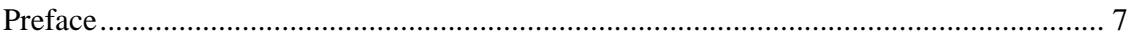

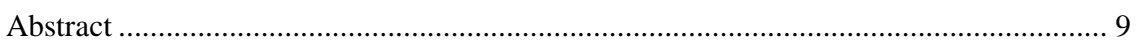

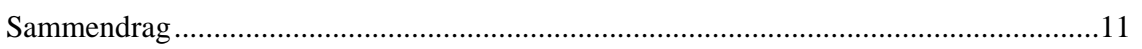

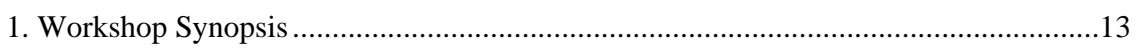

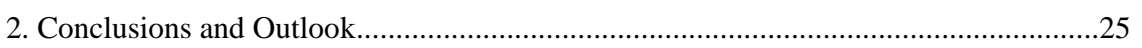

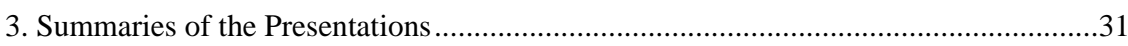

3.1 What are the implications of the Water Framework Directive for managing agricultural phosphorus?

Seppo Rekolainen

3.2 Phosphorus Losses in Agricultural Catchments in the Nordic and Baltic region Nils Vagstad, Hans E. Andersen, Arvo Iital, Viesturs Jansons, Katarina Kyllmar, Seppo Rekolainen, Rimvydas Tumas and Johannes Deelstra

3.3 Strengths and weaknesses of phosphorus models: EUROHARP.

Short summary

Oscar Schoumans

3.4 An Evaluation of Models to Assess the Risk of Phosphorus Loss from Agricultural Land to Water Louise Heathwaite..

3.5 The P Index: US Experience

Douglas Beegle.

3.6 Development of a Phosphorus index for Norway - Input data sources for the Skuterud catchment

Marianne Bechmann

3.7 Development of Swedish P index - how far can we reach with the existing knowledge?

Faruk Djodjic....

3.8 The VIHMA model - assessing measures to reduce erosion and P loss from agricultural land in Finland Markku Puustinen and Sirkka Tattari

3.9 Modifying and evaluating a P index for Denmark Hans Estrup Andersen and Brian Kronvang...

3.10 Incorporating Economics into P Risk Assessment Anni Huhtala

3.11 Economic effects of policies to reduce phosphorus from agriculture - a Danish perspective Berit Hasler and Jørgen Dejgaard Jensen

3.12 Using phosphorous loss assessment tools in practice Svein Skøien

3.13 The agricultural advisor's perspective Janne Linder

3.14 Using phosphorus loss assessment tools in practice - the agricultural advisor's perspective Leif Knudsen and Hans S. Østergaard

3.15 The need for assessment tools, research and cooperation Ingrid Rydberg.....

3.16 Using phosphorus loss assessment tools in practise. The river basin manager's perspective Jørgen Bidstrup 
4. Abstracts of the posters

4.1 Models, phosphorus and practical aspects, what are the relations?

Per N. Andersen, Ole Gregor and Carl Erik Bruntze

4.2 A statistical model for estimation of the different contributions to loading Ämer Bilaletdin, Heikki Kaipainen and Tom Frisk.

4.3 Surpluses of phosphorus in Danish agriculture Tommy Dalgaard, Gitte Rubcek, Jørgen F. Hansen, Arne Kyllingsbcek and Christen Duus Børgesen

4.4 A laboratory method for risk assessment of soil and P-losses Ararso Etana

4.5 Long-term studies of erosion and phosphorus load under different cultivation methods in three experimental fields in Finland Minna Kukkonen, Markku Puustinen, Riitta Niinioja, Juha Eskelinen and Eila Turtola

4.6 Quantification of Phosphorus Losses Through Macroporous Soils with a modified ICECREAM model Martin Larsson, Kristian Persson and Nick Jarvis.

4.7 Impact of Agriculture Decline on Phosphorus Loads to Lithuanian Rivers Arvydas Povilaitis

4.8 Nutrient balance - phosphorus management tool to minimise its application in a watershed Ausra Smitiene and Ginutis Kutra

4.9 Degree of Phosphorus Saturation for Rapid Risk Assessment of Phosphorus Losses in Southern Sweden Barbro Ulén and Jan Eriksson

4.10 Losses of suspended solids and phosphorus from small agricultural catchments in Norway

Stine Marie Vandsemb and Marianne Bechmann

4.11 Leaching of phosphorus from Danish sandy soils?

Lisbeth Wiggers

4.12 A systemic analysis for development of cereal growing in organic farming Hanne Weichel Carlsen and Tor Arvid Breland....

5. Programme

6. Participants 


\section{Preface}

Concern for the aquatic environment has been an important area of cooperation between the Nordic countries. This has again been highlighted by the Nordic Environmental Action Plan 2005-2008 (Nordic Council of Ministers, 2005), which stresses the common ground in the process of implementing the EU's Water Framework Directive in the Nordic countries. The workshop "Tools for Assessing Phosphorus Loss from Nordic Agriculture" held at the Danish Institute of Agricultural Sciences in February 2004 brought together experts working on developing risk assessment strategies for P loss in the Nordic and Baltic countries and is a practical manifestation of Nordic cooperation. This TemaNord report gathers the workshop contributions and provides an overview of the current development of decision tools to aid abatement of phosphorus losses from agriculture. The organizers express the hope that the conclusions from this workshop serve as a useful contribution in the debate on the development of an effective policy framework for tackling phosphorus losses from agricultural land.

The generous sponsorship by the Nordic Council of Ministers is gratefully acknowledged. 



\section{Abstract}

This TemaNord report presents the proceedings from the Nordic Council of Ministers sponsored workshop “Tools for Assessing Phosphorus Loss from Nordic Agriculture” jointly organized by five institutes from Denmark, Finland, Norway and Sweden that was held at Foulum, Denmark, February 2004. The purpose of the workshop was to discuss the role of practical tools for mitigation planning - specifically at the field and farm scale - to reduce phosphorus (P) losses from agricultural land.

Diffuse P losses from agricultural land now make up the biggest share of $\mathrm{P}$ inputs to the aquatic environment in the Nordic countries and are the main cause of eutrophication. Compliance with the Water Framework Directive will require a substantial reduction in agricultural P losses. This has created an urgent demand by environmental authorities and landusers for instruments that assess the risk of $P$ losses from agricultural land and facilitate the planning of mitigation measures. There is little evidence that general regulation aimed at lowering $\mathrm{P}$ inputs to agricultural land will result in the necessary reductions of $\mathrm{P}$ transfer to waters in the foreseeable future. The reason is that high-risk areas within agricultural landscapes contribute substantially more than others to P losses. Without addressing the role of high-risk areas for $\mathrm{P}$ loss and specifically $\mathrm{P}$ transport in landscapes, policy measures to abate diffuse $\mathrm{P}$ losses are likely to be inefficient. Due to the complexity of P loss processes the identification of high-risk areas and the administrative handling of mitigation strategies call for an objective risk assessment framework in the form of decision and mitigation planning tool.

The choice of tool crucially depends on the availability of data and the resources end-users are willing to expend on mitigation planning. Farmers and environmental managers are best served by user-friendly, qualitative decision tools with low data requirements for hands-on mitigation planning.

To date the Nordic countries lack a tested, practical risk assessment framework to guide mitigation planning that will reduce diffuse $\mathrm{P}$ losses to required levels. The central message from the workshop is a call for policymakers to prioritize the development and evaluation of simple, empirical risk assessment tools for diffuse P losses that are urgently requested by land-users and environmental authorities to support the WFD process. An interdisciplinary approach to model development with strong end-user participation is essential. Future tools must be compatible with market-based incentives. The process of development and implementation of such tools would greatly benefit from close Nordic collaboration utilizing different countries' experiences and synergies between relevant 
research groups. A single conceptual framework for a $\mathrm{P}$ decision tool is applicable in the Nordic and Baltic countries, even if it requires adaptations of its design. Important lessons can be learned both from the P index widely adopted in the United States and the UK-developed Phosphorus Indicators Tool regarding simplification of process knowledge and meeting end-user needs. 


\section{Sammendrag}

Med denne TemaNord-rapport afrapporteres workshoppen "Tools for Assessing Phosphorus Loss from Nordic Agriculture”, afholdt februar 2004 ved Danmarks JordbrugsForskning, Foulum. Workshoppen, sponsoreret af Nordisk Ministerråd, blev organiseret i et samarbejde mellem 5 forskningsinstitutioner i Sverige, Norge, Finland og Danmark. Rapporten indeholder foruden foredrag og posters, præsenteret på workshoppen, en synopsis af disse. Workshoppen havde til formål at diskutere, hvilken rolle praksisorienterede modelredskaber kan spille i planlægningen af tiltag rettet mod en reduktion af fosfortabet fra dyrket jord på såvel marksom bedriftskala.

I de nordiske lande udgør det diffuse tab af fosfor fra landbrugsjord nu det største enkeltproblem for vandmiljøkvaliteten. For at kunne overholde målsætningerne opstillet i EU's Vandrammedirektiv, vil det være nødvendigt at reducere det diffuse fosfortab betragteligt. Der er dermed et særdeles påtrængende behov for at udvikle redskaber og metoder, der kan anvendes af miljømyndigheder og -forvaltere, både til vurdering af risikoen for tab af $\mathrm{P}$ fra dyrket jord men også som støtte når det skal tages beslutning om iværksættelse af afværgeforanstaltninger. Der er ikke belæg for at antage, at tabet af P fra det dyrkede areal til vandmiljøet vil kunne reduceres i tilstrækkeligt omfang, i den nærmeste fremtid, ved blot generelt at reducere P-tilførslerne. Grunden er, at der lokalt i det agrare landskab vil forekommer højrisikoområder, som bidrager uforholdsmæssigt mere til tabet af fosfor end landbrugsarealet set under et. Ved ikke at tage højde for de kritiske kildeområder og især forekomst af effektive Ptransportprocesser i landskabet, risikerer foranstaltningerne til begrænsning af P-tab at blive ineffektive. Da P-tabsprocesserne er så komplekse, er der behov for at udvikle modelværktøjer, der kan bruges til at udpege de mest risikable områder.

Valget af modelværktøj vil være meget afhængig af hvilke data slutbrugeren har til rådighed og omfanget af ressourcer man er indstillet på at anvende til afhjælpning af problemerne. Landmænd og miljøforvaltere vil være bedst tjent med brugervenlige, kvalitative beslutningsstøtteværktøjer med lavt data behov for deres praksisorienterede afhjælpning af problemerne.

Der findes i de nordiske lande i dag intet aftestet, praksisnært risikovurderingssystem, som kan støtte og vejlede ved planlægning af initiativer, der kan reducere diffust tab af $\mathrm{P}$ i det nødvendige omfang. Nøglebeskeden fra workshoppen er at bede de politiske beslutningstagere om at opprioritere udviklingen og aftestningen af et relativt enkelt og empirisk værktøj, der kan bruges til at håndtere og løse problemerne med det dif- 
fust P-tab fra dyrket jord. Både brugere og forvaltere af det åbne land, men sandelig også de politiske beslutningstagere, står med et påtrængende problem. Ved udviklingen af værktøjerne interdisciplinær tilgang være nødvendig, og det vil være af afgørende betydning at involvere slutbrugerne og deres behov i processen. Fremtidige værktøjer må kunne tage højde for udvikling og ændring i markedsmekanismer herunder EU's fælles landbrugsstøtte. Udviklingen og implementeringen af sådanne værktøjer vil have stor gavn af en fælles nordisk indsats. Når det kommer til forsimpling af procesforståelse og at imødekomme slutbrugernes behov vil der kunne trækkes på erfaringer med P-indeks, som har en udbredt anvendelse i USA og Phosphorus Indicator Tool, som er udviklet i Storbritannien. 


\section{Workshop Synopsis}

Diffuse phosphorus ( $\mathrm{P}$ ) losses from agricultural land to water has become a major environmental concern in the Nordic countries since $\mathrm{P}$ is causing eutrophication and hence deterioration in the ecological quality of many freshwaters, estuaries and coastal waters (e.g. Borgvang et al., 2002; Søndergaard et al., 2003; Ekholm and Mitikka, 2005). Throughout the region $\mathrm{P}$ discharges from sewage treatment works and industry have declined dramatically over the past three decades, leaving agriculture as the main contributor of $\mathrm{P}$ to the aquatic environment in Denmark (Kronvang et al., 2001), Finland (Vuorenmaa et al., 2002), Norway (Berge et al., 2002) and Sweden (Johansson \& Persson, 2001). Intensive agricultural production in the Nordic countries has been closely linked with $\mathrm{P}$ accumulation in soils (e.g. Andersson et al., 1998; Haraldsen et al., 2001). There have been two important drivers for this enrichment. Soils have an inherent, yet limited, capacity to bind $\mathrm{P}$ resulting in naturally low plant $\mathrm{P}$ availability. Over the past century it had made economic sense to raise the P fertility of soils by applying P fertilizers. Additionally and increasingly over the past decades intensive animal production has been associated with a large $\mathrm{P}$ surplus, which agricultural soils have almost inevitably served as the ultimate store for. As P enrichment of soils rises, P is increasingly leaking from this store (Rekolainen et al., 1997).

In the light of the EU Water Framework Directive (WFD) it is essential to analyze pressures and establish targeted measures for the control of $\mathrm{P}$ losses from agricultural land if the ambitious quality goals for surface waters in the Nordic ${ }^{1}$ and Baltic countries are to be achieved. Hence, there is a general consensus in the Nordic countries that efforts to abate $\mathrm{P}$ losses from agricultural land have to be intensified (e.g. Swedish Environmental Protection Agency, 2004; Granlund et al, 2005; Kronvang et al., 2005; State Pollution Control, 2005). This has created an urgent demand by environmental authorities and not least land-users for instruments that assess the risk of $\mathrm{P}$ losses from agricultural land and simultaneously facilitate the planning of mitigation measures (Dørge \& Windolf, 2003; Rekolainen et al., 2003).

Phosphorus loss is a complex function of climate, topography, soil type and land management and varies greatly both temporally and spatially. High-risk areas thus contribute substantially more than others to $\mathrm{P}$ losses within agricultural landscapes (e.g. Heathwaite et al., 2003a). These so-called critical source areas (CSA) for P loss occur where an

\footnotetext{
${ }^{1}$ Norway is officially committed to implementing the WFD through the framework of the EEAagreement.
} 
efficient transport process links an area containing substantial amounts of potentially mobile P to a water body (Gburek et al., 2000). The identification of critical source areas is a prerequisite for implementing focused and hence cost-effective mitigation measures (e.g. Johansson \& Randall, 2003) that may address both $P$ input and status in soils and $P$ transport in landscapes. This can be accomplished by means of simple assessment tools like the P index, which is now widely used in the United States to rank fields according to their vulnerability to potential P loss (Sharpley et al., 2003). Another recent example is the UK-developed Phosphorus Indicators Tool (PIT), which integrates P sources, $\mathrm{P}$ transfer and $\mathrm{P}$ delivery to watercourses and predominantly utilizes data from accessible (national) databases. PIT operates at a $1 \mathrm{~km}^{2}$ scale and screens for larger areas within catchments with a high risk of $\mathrm{P}$ loss from land to water (Heathwaite et al., 2003a).

Due to the large amounts of $\mathrm{P}$ already accumulated in soils, regulatory measures designed to reduce the $\mathrm{P}$ surplus in agriculture or to limit the use of $\mathrm{P}$ fertilizers in general, might take decades to translate into loss reductions (e.g. Johnes, 1996). It is however the fields with the highest soil $\mathrm{P}$ status that will show the greatest drop in potential $\mathrm{P}$ mobility and hence P loss potential once P inputs are reduced (e.g. Ekholm et al., 2005). The Finnish Agri-Environmental Programme (Ministry of Agriculture and Forestry, 2004) is a comprehensive financial incentives programme to control $\mathrm{P}$ losses by encouraging farmers to implement integrated mitigation plans including reduced fertilizer $\mathrm{P}$ inputs, establishment of buffer zones and wetlands. Though widely subscribed to and costly, the programme has not noticeably reduced $\mathrm{P}$ losses from agricultural land, partly because it failed to target the areas most vulnerable to $\mathrm{P}$ losses (Granlund et al., 2005). Further telling examples are the Baltic countries where fertilizer and manure $\mathrm{P}$ inputs have decreased substantially since the late 1980s without generally resulting in reduced P losses (Stålnakke et al., 2004). A few successes have been reported from Norway (Bechmann \& Stålnakke, 2005) and southern Sweden (Ulén \& Fölster, 2005) and relate to catchments where the targeting of high risk areas of erosion has led to a small decline in diffuse P loads in streams. In other words, without addressing the role of CSA and hence excessively high P contents in soils and especially $\mathrm{P}$ transport in landscapes, policy measures to abate diffuse P losses are likely to be ineffectual (Ekholm et al., 2005; Heathwaite et al., 2005). Nevertheless, uniform reduction policies are attractive to policymakers, since they are easily implemented and monitored and common sense. For example, the latest Action Plan for the Aquatic Environment addressing abatement of agricultural $\mathrm{P}$ losses in Denmark (Ministry of the Environment, 2004) requires halving the national P surplus in combination with widespread, yet non-targeted, establishment of riparian buffer zones by 2015 . 
Phosphorus delivery to water bodies can be reduced by decreasing the availability of $\mathrm{P}$ for mobilization in soils or at the soil surface and by manipulating the runoff flowpaths so that $\mathrm{P}$ can be stripped again from the runoff (Ulén \& Jakobsson, 2005). Therefore, many mitigation strategies require management decisions best taken at the field and farm scale. Due to the complexity of $\mathrm{P}$ loss processes systematic mitigation planning at larger scales calls for an objective risk assessment framework warranting equal standards. To date a range of different predictive modelling tools is available from field to river basin scale (e.g. Schoumans \& Silgram, 2003). However, the resources end-users are able and willing to allocate to mitigation planning dictate the degree of sophistication such models may have. Therefore, farmers undoubtedly need practical and user-friendly decision tools to enable appropriate mitigation measures to be installed in the right places. The same applies to environmental authorities for systematic administration and evaluation of such measures. Preferably both stakeholder groups should employ the same tools.

The development of such tools for the Nordic region still is at an early stage and must therefore become a priority in the coming years. To stimulate and further this development across the region, five institutes from Denmark, Norway, Sweden and Finland jointly organized a Nordic workshop as an international discussion forum for researchers, land managers and land-users. The workshop "Tools for Assessing Phosphorus Loss from Nordic Agriculture" was held at the Danish Institute of Agricultural Sciences, Research Centre Foulum, 2-3 February 2004. The focus was on practical tools for assisting mitigation planning at the field and farm scale. The specific objectives of the workshop were i) to clarify the scope and limitations of different risk assessment tools for $\mathrm{P}$ loss, ii) to present examples of risk assessment exercises from Nordic countries, iii) to examine perspectives for integrating socio-economic analysis with risk assessment and iv) to outline perspectives for development of existing tools. Fiftythree people, one-third of whom came from outside the scientific community, attended the workshop. The programme was structured into five topical sessions (see Workshop Programme, Chapter 5) summarized below. Chapter 3 contains the extended abstracts of the presentations and Chapter 4 the poster abstracts.

\section{Impact of agricultural phosphorus on water quality}

Rekolainen (Chapter 3.1) outlined a conceptual framework for identifying the role of models in the various phases of the EU Water Framework Directive implementation process. The WFD commits member states to establishing very high water quality standards in all aquatic environments within the EU. Compliance with the WFD has therefore created an enormous drive towards improving ecological quality of costal and inland waters. Within the WFD process the risk from all human activity is as- 
sessed and combined with information on the sensitivity of receiving waters to pressures such as P loss, in order to identify the waterbodies in danger of not meeting the quality standards. On this basis efficient strategies to abate diffuse P losses are to be developed. However, the research into linking $\mathrm{P}$ sources in landscapes to ecological impacts in surface waters is still at an early stage (Haygarth et al., 2005). Due to the complexity of the biophysical processes involved, successful implementation of the WFD requires mathematical models and other tools to manage different phases of the planning procedure and to support decision-making in various steps of the implementation process (Rekolainen et al., 2003). Predicting the required reduction of $\mathrm{P}$ input to waters for achieving the desired ecological quality remains a major challenge.

Nutrient transport in watercourses has been intensively monitored in the Nordic countries. The contribution of agricultural P losses to riverine $\mathrm{P}$ transport has typically been determined by means of indirect methods such as source apportionment (e.g. Kronvang et al., 2001) and in combination with detailed field studies. Vagstad et al. (Chapter 3.2) discussed P losses from 35 typical Nordic and Baltic agricultural catchments. Phosphorus losses varied substantially in space and time with mean annual $\mathrm{P}$ loads ranging from a few hundred grams to several kilograms per hectare. Catchments vulnerable to erosion tended to lose most P. The bioavailability of exported $\mathrm{P}$ varied too, underlining the importance of including ecological impact in risk assessment of $\mathrm{P}$ losses. Phosphorus losses showed no correlation with annual $\mathrm{P}$ surpluses in catchments and instead were best explained by variations in runoff. Testing different riverine $\mathrm{P}$ transport models Andersen et al. (2005) obtained the same results for a large number of Danish catchments. This underlines the crucial importance of addressing $\mathrm{P}$ transport, and not solely soil $\mathrm{P}$ accumulation, in mitigation strategies for $\mathrm{P}$ losses from agricultural land.

Phosphorus losses from Baltic catchments were similar to those in Denmark and Sweden (Vagstad, Chapter 3.2). Baltic agriculture was in the Soviet period characterized by large but regionally varying fertilizer and manure P inputs. However, since independence production intensity has declined in many areas, which rather increased the variation in the risk of P losses from agricultural land and the need for screening for highrisk areas (Iital et al., 2005).

\section{Tools for assessing phosphorus loss}

Based on the recognition that modelling tools are essential in the WFD process, Schoumans (Chapter 3.3) discussed different model concepts for dealing with $\mathrm{P}$ losses. Modelling tools differ widely in their approach to predicting diffuse $\mathrm{P}$ losses from soil to water, i.e. in their complexity, their representation of processes and pathways (empirical, physical) and their resource requirements (data, time). A basic distinction can be made 
into simple screening tools for identifying high-risk areas and complex scenario analysis tools for exploring management options in abating $\mathrm{P}$ losses from agricultural land. Apart from task-depending criteria, essential determinants for the choice of model are therefore the costs end-users are willing to bear and the skills required for running the models. Deterministic physically-based models of diffuse P loss simulate complex ecological processes and their interactions. They are invaluable as research tools in the furtherance of process understanding. They also provide the means for assessing the impact of P loss on water quality and hence mitigation targets at the river basin scale. However, as they are frequently sparse data sets and require complicated parameterization, these models are unsuitable for end-users conducting practical risk assessment and mitigation planning. A web-based public toolbox is developed by the EUROHARP project (http://euroharp.org/) to assist potential model users in the selection of appropriate models depending on the actual catchment typology and assessment purpose.

Following up on the general model considerations, Heathwaite (Chapter 3.4) evaluated different empirical, semi-distributed model approaches that estimate the risk of $\mathrm{P}$ loss based on limited data. The planning and implementation of efficient mitigation measures clearly requires that endusers including farmers, advisory services and government agencies are equipped with simple, user-friendly management tools. Recent examples are index-type tools that build on expert knowledge rather than complex process representation for linking identified risk to mitigation measure. Their success depends on the accurate and sensitive treatment of spatial data, which is accomplished by incorporating the critical source area concept. Although a single conceptual framework for a simple risk assessment tool may be applicable in the Nordic countries, its development must properly account for the regional differences in topographic, hydrologic and management conditions (Heathwaite et al., 2003b). In the past most best management practices (BMPs) to reduce P losses focused on controlling nutrient sources. However, directing measures at the transport pathways is likely to have a more immediate effect on P losses to waters rendering measures more efficient and cost-effective (Heathwaite et al., 2005).

It remains a challenge for science to upscale small-scale $\mathrm{P}$ transport processes to field and catchment scale patterns of diffuse P loss. It is also vital to recognize the limitations of these simple empirical models. They cannot quantify ecological impact of P loss in waters because they are not dynamic. They only crudely distinguish loss of different $\mathrm{P}$ forms and, crucially, only predict potential P loss. The ecological impact, however, depends on the $\mathrm{P}$ form, interactions with other nutrients, temporal variation in P loading and internal recycling of P.

In Chapter 3.5 Beegle summarized experiences with the P index in the United States where the US Environmental Protection Agency ranks eu- 
trophication as the most widespread water quality impairment. The $\mathrm{P}$ index approach is based on the recognition that most $\mathrm{P}$ is lost to water during a few large storm events from only a small area of the landscape, i.e. critical source areas. Hence, the P index comprehensively accounts for both source (soil test $\mathrm{P}$, fertilizer and manure management) and transport factors (erosion, runoff, leaching, connectivity to receiving waters) for identifying fields most at risk of $\mathrm{P}$ loss. The $\mathrm{P}$ index uses readily available information on source and transport factors and is specifically aimed at land-users and advisors. It is a purely qualitative predictor of risk and directly provides site-specific management guidance to minimize P loss based on identified critical source or transport factors, or both. Most states have now adopted $\mathrm{P}$ indices by modifying the basic components to make it suitable for local conditions (Sharpley et al., 2003). This makes it the only officially recommended empirical risk assessment tool for P loss. Such widespread adoption reflects the general consensus amongst farmers and environmental authorities regarding the validity of the $\mathrm{P}$ index approach. Phosphorus indices generally identify only relatively few fields within the catchment in need of improved $\mathrm{P}$ management, hence limiting the economic impact on producers while capping the largest P losses. Combined with the flexibility to choose site-specific measures this makes $\mathrm{P}$ index-based mitigation cost-effective and acceptable to landusers. Recently the $\mathrm{P}$ index has been explored as a tool for evaluating the cost-effectiveness of mitigation planning (Johansson \& Randall, 2003).

A current drawback of the $\mathrm{P}$ index is the lack of direct calibration and the uncertainty related to delineation of risk classes. The translation of quantitative data or scores into qualitative classifications of low or high risk remains a challenge, which has become a research priority. However, an extensive runoff plot study (Sharpley et al., 2001) and a recent comparison of measured and simulated $\mathrm{P}$ losses with indexed site vulnerability (Veith et al., 2005) both indicated that the P index provides a reliable assessment of where $P$ losses occur within a catchment. Another practical limitation of the $\mathrm{P}$ index from a farmer's perspective is the length of time required to evaluate the soil parameters used in estimating erosion and runoff potential. This suggests an important role for linking geographic databases directly to P index assessments (Beegle et al., 2000).

\section{Experiences with $P$ index tools in the Nordic countries}

To date tools for comprehensively assessing the risk of P loss are not part of officially recommended or required mitigation planning in any Nordic country. However, responding to the challenges presented by the WFD, research on the development and feasibility of different risk assessment modelling tools has been conducted in Denmark, Finland, Norway and 
Sweden in recent years. Some results of that research are presented in the following.

The Pennsylvania P index was adapted for use in Norway. Bechmann (Chapter 3.6) gave a detailed description of its application to an arable catchment dominated by cereals. Important modifications to the P index included the recognition of $\mathrm{P}$ surpluses, the release of $\mathrm{P}$ from plant material following freezing and a $\mathrm{P}$ leaching risk ranked according to soil type. A test of the first version of the Norwegian P index at the catchment scale indicated that the index satisfactorily ranked fields according to the risk of P loss compared with measured losses (Bechmann et al., 2005). They concluded that the $\mathrm{P}$ index was a valuable field-scale decision support tool for nutrient management planning in Norway. Input data for the $\mathrm{P}$ index are available from farmers and statistical sources. The presented $\mathrm{P}$ index is not a fully developed tool for Norwegian conditions, since the factors are not weighted according to their actual influence on P losses. For example, the erosion risk was underestimated in the present Norwegian P index. Calibration of the P index is needed before it can be used with confidence to identify high-risk areas of P loss in Norway.

Djodjic (Chapter 3.7) presented the concept of the conditional P index (PI) developed for Swedish conditions as an educational and P management tool for farmers and agricultural advisors. The Swedish PI resembles the US P index to a lesser degree than the one adopted in Norway, though it is still a qualitative assessment tool essentially structured into source and transport factors. Because the significance of certain factors for $\mathrm{P}$ losses depends on interactions with other factors, conditional rules are needed for a more accurate process description. Accounting for $\mathrm{P}$ losses through the soil profile, separate considerations of reactive and unreactive $\mathrm{P}$, a measure of $\mathrm{P}$ saturation in soils, and a changed approach to assessing $\mathrm{P}$ loss due to erosion are some of the additional features included in the tool presented here not included in US indices. To facilitate the calculation process and avoid procedural mistakes, an interface in the form of a Visual Basic application has been built. The performance of the tool was tested by comparing the calculated PI values with measured annual P transport from seven field sites included in the Swedish water quality monitoring programme (Djodjic and Bergström, 2005). This first test indicated that the tool could be used successfully for assessing the risk of $\mathrm{P}$ loss.

In Finland the VIHMA assessment tool was developed to estimate the P load from agricultural land, to target mitigation measures according to cost effectiveness, and to assess the relevance of annual variations in climatic and runoff variables for mitigation planning (Puustinen, Chapter 3.8). VIHMA basically operates at the field scale, but can be upscaled to any scale. The risk of P loss is determined as a function of field slope, soil type, cultivation practice, $\mathrm{P}$ status and soil drainage - all generally accessible data. The influence of each factor on P loss and the effect of 
mitigation measures were derived from field experiments. Costs were determined for the different mitigation measures. They concluded that the choice of mitigation measures must be flexible and based on local conditions. The variety of farming conditions in combination with different mitigation options available confounds mitigation planning. The VIHMA tool makes the mitigation process more transparent and at the same time enables assessment of the allocation of environmental subsidies.

Andersen and Kronvang (Chapter 3.9) modified the Pennsylvania P index to account for $\mathrm{P}$ loss in drains and $\mathrm{P}$ leaching from soils, which are two important pathways of $\mathrm{P}$ transport in Denmark. The modified and the original P index were applied to a $1000 \mathrm{~km}^{2}$ catchment, where relevant information on source and transport factors was available at the field block level. A field block consists of one or several fields and is bordered by permanent landscape structures such as roads, streams or hedgerows. To test the performance of the indices Andersen and Kronvang examined their ability to correctly rank measured annual diffuse P losses from twelve subcatchments within the $1000 \mathrm{~km}^{2}$. The modified $\mathrm{P}$ index performed distinctly better than the original explaining $85 \%$ of the variation in measured P losses. The results have encouraged the further development of a P index tool to identify critical source areas in Danish catchments.

Socio-economic implications of reducing phosphorus loss from farmland

Agricultural production impacts the environment causing costs to society, and $\mathrm{P}$ losses to sensitive water bodies are one example. As optimization of agricultural output is the farmer's foremost goal, 'free' markets generate pollution and its prevention or abatement requires government intervention (Huhtala, Chapter 3.10). Huhtala discussed information problems for handling policy instruments directed at diffuse P losses: who pollutes, how much and to what environmental effect? Policy instruments could either be market-based incentives for pollution control, such as taxes, subsidies or tradeable permits, or general regulation. Lack of market transparency makes it difficult to estimate the level of pollution abatement achieved by market mechanisms, while general regulation has a predictable outcome, though is likely to be less cost effective (Johansson, et al., 2004). Therefore, market-based instruments linked only to indirect indicators of pollution, like $\mathrm{P}$ fertilizer use, might be much less costefective than direct pollution taxes. The more accurately an environmental indicator reflects the impact on the environment, the more efficiently the policy instrument linked to the indicator works. Here an integrated assessment tool like a P index is seen as a good candidate in connection with implementing market-based incentives. 
Part of the WFD process is determining the costs of pollution abatement that agriculture and society as a whole incur as the basis for choosing the most cost efficient solution. Given the wide range of options available to policy-makers, models linking mitigation of $\mathrm{P}$ losses to the cost of achieving mitigation are essential for informed decisions. That is, under finite financial resources measures are then installed where they have the greatest effect. Hasler and Dejgaard (Chapter 3.11) pointed out that economic research into $\mathrm{P}$ regulation is very limited in Denmark and other Nordic countries in general. Policy instruments focussing on direct reductions of $\mathrm{P}$ losses locally, at the scale where mitigation measures are best installed, are hampered by the lack of tested and accepted tools for identifying critical source areas for P loss. Therefore, there is a tendency to link policy instruments to measurable fluxes of feed and fertilizer $\mathrm{P}$ in Danish agriculture, thus only addressing the problem of $\mathrm{P}$ surplus in agriculture. However, this strategy is likely to prove inefficient in reducing current losses. Agricultural soils already enriched in $\mathrm{P}$ will continue to release $\mathrm{P}$ to waters in the foreseeable future unless transfer processes are being addressed directly concluded studies from Finland (Granlund et al., 2005) and the UK (Heathwaite et al., 2005). Hasler and Dejgaard suggest that economic analysis in conjunction with a P indexing approach would help implement and administer cost-effective mitigation solutions.

\section{Using phosphorus loss assessment tools in practice}

'Research providers' and 'research users' need to reach an understanding on common goals as the prerequisite for developing risk assessment tools that are successful in practice and accepted by end-users. In the following, examples are given of how $\mathrm{P}$ loss is being dealt with by agricultural advisors and water district managers in the Nordic countries and their views on the perspectives for the development of risk assessment and mitigation planning tools.

In Norway municipalities provide agricultural advisory service and are the competent authorities dealing with matters of agricultural and environmental administration (Skøien, Chapter 3.12). They are responsible for the practical implementation of the WFD and regulate land use accordingly by adopting water management plans. Since agriculture is the largest contributor of $\mathrm{P}$ to surface waters in areas with large proportions of cultivated land, mitigating $P$ losses is an important task for municipalities. Phosphorus losses are primarily being addressed through volunteer conservation schemes in close collaboration with the advisory service. This is supported by a financial incentives programme focusing on erosion and offering farmers graded support for installing a variety of conservation measures. Thus, higher conservation grants are awarded for reduced tillage in areas of greater erosion risk. To administer conservation grants cost-effectively, some municipalities have adopted a simpli- 
fied $\mathrm{P}$ indexing system for identifying critical source areas especially for erosion (e.g. Lundekvam et al., 2003). Indexing is viewed as a valuable tool for decision-making and Skøien stressed the importance of simplicity in tool design.

Linder (Chapter 3.13) focused on nutrient management planning as a means of controlling $\mathrm{P}$ inputs to agricultural land and thus avoiding $\mathrm{P}$ accumulation in soils. In Sweden livestock density is restricted to an equivalent of $22 \mathrm{~kg} P$ per hectare and excess manure $\mathrm{P}$ has to be exported from farms. With the national $\mathrm{P}$ balance showing a surplus of only $2 \mathrm{~kg} \mathrm{P}$ per hectare it was conceded that regulating $\mathrm{P}$ applications alone would not greatly reduce $\mathrm{P}$ losses. Sweden also operates a scheme of financial support for installing mitigation measures such as riparian buffer zones and wetlands. Conservation measures are further promoted through information campaigns led by the advisory service, which encourages farmers to draw up a nutrient management and conservation plan. Linder concluded that advisors would benefit from a qualitative assessment tool provided it was transparent for farmers and advisors and simple to apply so that the tool would gain acceptance in the farming community.

Knudsen and Østergaard (Chapter 3.14) gave an overview over P cycling in Danish agriculture, $\mathrm{P}$ accumulation in soils and the trend of plantavailable $\mathrm{P}$ contents in soils. Due to reductions in fertilizer P consumption $\mathrm{P}$ surpluses had declined to an average of $13 \mathrm{~kg} \mathrm{P}$ per hectare in 2003. Over the past decade plant-available $P$ in commercial samples analysed by the advisory service showed a slight downward trend. This pointed to a dilemma for crop producers. While there is an environmentally motivated drive towards eliminating $\mathrm{P}$ surplus additions to soils, this may impair soil $\mathrm{P}$ fertility with consequences for crop productivity. Knudsen and Østergaard raised the issue that declining contents in soils of plant-available $\mathrm{P}$ ought to lower the risk of $\mathrm{P}$ leaching and requested a sound scientific analysis of the agronomic and environmental consequences of significantly reduced $\mathrm{P}$ surpluses. The advisory service in Denmark favours the identification of critical source areas in landscapes and the subsequent targeting of mitigation measures, especially at $\mathrm{P}$ transport. The necessity of a simple tool based on accessible data combined with an efficient advisory system was stressed.

Rydberg (Chapter 3.15) reported on the ambitious national strategy in Sweden to eradicate eutrophication (Swedish Environmental Protection Agency, 2004). By 2010 anthropogenic emissions of P to lakes and streams in Sweden will have to be reduced by 20\% compared to the 1995 level. This process will be guided and administered by the Swedish EPA. Monitoring and mitigation planning relies on models and accessible emission statistics. Rydberg highlighted flaws in both, which compromises the setting of realistic reduction targets and mitigation strategies in general. The Swedish experience stresses the need for all stakeholders, i.e. researchers, land-users and environmental authorities, to cooperate 
closely throughout the whole WFD process from the design of risk assessment tools to the development of realistic abatement strategies and monitoring of mitigation success.

Bidstrup (Chapter 3.16) presented a practical insight into the work of Danish river basin managers. Mariager Fjord is a medium-sized eutrophic fiord in Denmark that had been affected by algal blooms in the past. Before the late 1990s the focus was on reducing $\mathrm{P}$ emissions from sewage treatment works and fish farms. Thereafter the river basin authority has drawn up a river basin management plan starting with the definition of ecological objectives in line with WFD requirements. Model simulations indicated that anthropogenic P emissions into Mariager Fjord, more than half of which came from agriculture, have to be reduced by $60 \%$ to meet the objectives. These predictions, however, were flawed since particulate $\mathrm{P}$ was not appropriately accounted for, thus underestimating the ecological impact of diffuse P losses. Cost-effectiveness analyses show that efforts to further reduce non-agricultural $\mathrm{P}$ emissions would be highly ineffective. Though the river basin authority also has lobbied for a general reduction of the agricultural $\mathrm{P}$ surplus in the catchment, a targeted effort to reduce P transport has been prioritized. Hence, the authority urgently requests an appropriate risk assessment tool. 



\section{Conclusions and Outlook}

Diffuse P losses from agricultural land cause eutrophication in most standing water bodies and some streams in the Nordic countries. To a lesser degree this is also true for the Baltic countries, where municipal point sources make a comparatively larger contribution to P loads in surface waters (e.g. Iital et al., 2005). Compliance with the EU WFD requires an improvement in ecological quality of those waters and hence a reduction of diffuse agricultural $P$ losses. These are a complex function of climate, topography, soil type and land management and vary greatly both temporally and spatially. For a given land unit the risk of $\mathrm{P}$ loss rises with increasing $\mathrm{P}$ accumulation in soils resulting from persistent $\mathrm{P}$ surplus additions of manure and fertilizer P. However, at the catchment scale $\mathrm{P}$ losses to waters were usually not correlated with annual P surpluses, but were instead best explained by variations in runoff. Therefore, there is little evidence that uniform regulation aimed at lowering $\mathrm{P}$ inputs to all agricultural land will result in reductions of $\mathrm{P}$ transfer to waters in the foreseeable future. Such regulation merely represents a step towards sustainable nutrient management in general, preventing a future rise in $\mathrm{P}$ losses. It is to be pointed out that the farming community also requests an analysis of the agronomic consequences of declining soil P status.

There exist high-risk, or critical source areas, within agricultural landscapes that contribute substantially more than others to P losses. Without addressing the role of critical source areas for $\mathrm{P}$ loss and specifically $\mathrm{P}$ transport in landscapes, policy measures to abate diffuse $\mathrm{P}$ losses are likely to be ineffective. The complexity of P loss processes calls for modelling tools that permit identification of the most vulnerable areas. Thus, appropriate mitigation measures can be targeted to limited areas in catchments. Agricultural advisors backed environmental managers in their urgent request for an objective risk assessment framework ensuring equal standards.

Many mitigation strategies require management decisions best taken at the field or farm scale. Therefore the workshop was primarily concerned with risk assessment tools operating at those scales. The choice of modelling tool crucially depends on the availability and accessibility of data and on end-users being able and willing to pay for for mitigation planning. Physically-based, data-hungry models for simulating transport and ecological processes are invaluable research tools. On the other hand, farmers and environmental managers experience severe cost constraints and are best served by user-friendly, qualitative decision tools for handson mitigation planning. The purpose and limitations of any risk assessment tool must be clearly defined as different end-user groups may have 
different expectations of the capabilities of the tool. A crucial distinction would be between the use purely for best management advice and the use as a pollution indicator to which policy instruments and mitigation evaluations may be linked.

'Free' markets generate pollution and its prevention or abatement requires government intervention. The establishment of measures to reduce P losses, therefore, comes at a cost for farmers and society. Increasingly, market-based incentives such as subsidies, taxes or tradeable permits are advocated as policy instruments for reducing diffuse P losses, because they are considered most cost-effective. Given the wide range of options available to policy makers, models linking mitigation of $\mathrm{P}$ losses to the cost of achieving mitigation are essential for informed decisions. However, economic analyses of P mitigation are very limited in Nordic countries and ought to be prioritized in the future.

Two rather simple, generic modelling tools based on expert knowledge stand out. Firstly, the P index of the United States, because it is the most widely used advisory tool for assessing $\mathrm{P}$ loss and its mitigation at the field scale and the only one officially recommended by a government authority. Cost-effectiveness analyses can be based on the P index and market-based incentives may be linked to the $\mathrm{P}$ index. Due to its robustness and flexibility the $\mathrm{P}$ index is now increasingly adopted in Europe at research level. Secondly, the Phosphorus Indicators Tool, because it is officially used in the UK as a screening tool for the Department for Environment, Food and Rural Affairs (DEFRA) to identify regions at risk of diffuse $\mathrm{P}$ loss and because of the research effort invested in its development. Important lessons can be learned from these two examples regarding simplification of process knowledge and meeting end-user needs. It may be interesting to apply a form of PIT in countries where P losses vary regionally and where agricultural censuses and geographic databases are available. PIT may therefore particularly suit the Baltic countries.

To date the Nordic countries lack a tested, practical risk assessment framework to guide mitigation planning towards actual reductions in diffuse P losses. However, simple empirical tools accounting for both source and transport factors are at the development stage, and their further development and evaluation must become a research priority in the Nordic countries. An interdisciplinary approach is required and collaboration with the farming community and environmental authorities from the start is vital for the establishment of a viable tool that meets the needs of end-users. Future tools must be compatible with market-based incentives. Any such tool would greatly benefit from an integrated web-based information system that links different data sources, provides guidance to users in applying the tool, and facilitates mitigation evaluation by environmental authorities. The development and implementation of such tools would greatly benefit from close Nordic collaboration utilizing complementary experiences and synergies between relevant research groups. 


\section{References}

Andersen, H.E., Kronvang, B. \& Larsen, S.E. (2005), Development, validation and application of Danish empirical phosphorus models. Journal of Hydrology, vol. 304, pp. 355-365.

Andersson, A., Andersson, R., Eriksson, J. \& Mattsson, L. (1998), Phosphorus accumulation in Swedish agricultural soils. Swedish Environmental Protection Agency, Stockholm, Report vol. 4919, ISSN 0282-7298.

Bechmann, M., Krogstad, T. \& Sharpley, A.N. 2005. A phosphorus index for Norway. Acta Agriculturae Scandinavica, Section Soil and Plant Sci. (Accepted)

Bechmann, M. \& Stålnakke, P. (2005), Effect of policy-induced measures on suspended sediments and total phosphorus concentrations from three Norwegian agricultural catchments. Science of the Total Environment, vol. 344, pp. 129-142.

Beegle, D.B., Sharpley, A.N., Gburek, W.J. \& Weld J. (2000), Integrating the Phosphorus Index and existing data bases for use in nutrient management planning. Department of Agronomy, Penn State University, Pennsylvania.

Berge, D., Vandsemb, S.M. \& Bechmann, M. (2002), JOVÅ - Overvåking av jordbrukspåvirkede innsjøer 2000. Tiltaksgjennomføring, vannkvalitet og utvikling. NIVA rapport nr. 4470-02.

Borgvang, S., Selvik, J.R. \& Tjomsland, T. (2002), Input of nutrients to Norwegian coastal areas calculated with the input model TEOTIL. Norwegian Institute for Water Research. ISBN 82-5774308-9, pp. 46.

Djodjic, F. \& Bergström, L. (2005), Conditional phosphorus index as an educational tool for risk assessment and phosphorus management. Ambio, vol. 34(3-4), pp. 296-300.

Dørge, J. \& Windolf, J. (2003), Implementation of the Water Framework Directive - can we use models as a tool in integrated river basin management? International Journal of River Basin Management, vol. 1, pp. 165-171.

Ekholm, P. \& Mitikka, S. (2005), Agricultural lakes in Finland: current water quality and trends. Environmental Monitoring \& Assessment (in press).
Ekholm, P., Turtola, E., Grönroos J., Seuri P. \& Ylivainio, K. (2005), Phosphorus loss from different farming systems estimated from soil surface phosphorus balance. Agriculture, Ecosystems \& Environment (in press).

Gburek, W.J., Sharpley, A.N., Heathwaite, A.L. \& Folmar, G. (2000), Phosphorus management at the watershed scale: a modification of the P Index. Journal of Environmental Quality, vol. 29, pp. 130-144.

Granlund, K., Räike, A., Ekholm, P., Rankinen, K. \& Rekolainen, S. (2005), Assessment of water protection targets for agricultural nutrient loading in Finland. Journal of Hydrology, vol. 304, pp. 251-260.

Haraldsen, T. Loigu, E., Iital, A., Jansons, V. \& Vagstad, N. (2001), Plant nutrients in soils and cereals in Norway and the Baltic countries. Jordforsk report no. 105/01, Norwegian Centre for Soil and Environmental Research, 22 pp.

Haygarth, P.M., Condron, L.M., Heathwaite, A.L., Turner, B. \& Harris, G.P. (2005), The phosphorus transfer continuum: linking source to impact with an interdisciplinary and multiscaled approach. Science of the Total Environment, vol. 344, pp. 5-14.

Heathwaite, A.L., Fraser, A.I., Johnes, PJ., Hutchins, M., Lord, E. \& Butterfield, D. (2003a), The phosphorus indicator tool: a simple model of diffuse $\mathrm{P}$ loss from agricultural land to water. Soil Use \& Management, vol. 19, pp. 111.

Heathwaite, A.L., Quinn, P.F. \& Hewett, C.J.M. (2005), Modelling and managing critical source areas of diffuse pollution from agricultural land using flow connectivity simulation. Journal of Hydrology, vol. 304, pp. 446-461.

Heathwaite, A.L., Sharpley, A.N. \& Bechmann, M. (2003b), The conceptual basis for a decision support framework to assess the risk of phosphorus loss at the field scale across Europe. Journal of Plant Nutrition and Soil Science, vol. 166, pp. 447-458.

Iital, A., Stålnakke, P., Deelstra, J., Loigu, E. \& Pihlak, M. (2005), Effects of large-scale changes in emissions on nutrient concentrations in Estonian riv- 
ers in the Lake Peipsi drainage basin. Journal of Hydrology, vol. 304, pp. 261-273.

Johansson, H. \& Persson, G. (2001), Swedish lakes with high phosphorus concentrations - 790 natural eutrophic or eutrophicated lakes. Bulletion 2001/8, Institute of Environmental Assessment, Uppsala, 15 pp.

Johansson, R.C., Gowda, P.H., Mulla, D.J. \& Dalzell, B.J. (2004), Metamodelling phosphorus best management practices for policy use: a frontier approach. Agricultural Economics, vol. 30, pp. 63-74.

Johansson, R.C. \& Randall, J.R. (2003), Incorporating economics into the phosphorus index: an application to US watersheds. Journal of Soil and Water Conservation, vol. 58(5), pp. 224-231.

Johnes, P.J. (1996), Evaluation and management of the impact of land use change on the nitrogen and phosphorus load delivered to surface waters: the export coefficient modelling approach. Journal of Hydrology, vol. 183, pp. 323-349.

Kronvang, B., Iversen, H.L., Jørgensen, J.O., Paulsen, I., Jensen, J.P., Conley, D., Ellermann, T., Laursen, K.D., Wiggers, L., Flindt Jørgensen, L. \& Stockmarr, J. (2001), Fosfor i jord og vand. Udvikling, status og perspektiver. National Environment Research Institute, NERI Report no. 380, 88 pp.

Kronvang, B., Jeppesen, E., Conley, D.J., Søndergaard, M., Larsen, S.E., Ovesen, N.B. \& Carstensen, J. (2005), Nutrient pressures and ecological responses to nutrient loading reductions in Danish streams, lakes and coastal waters. Journal of Hydrology, vol. 304, pp. 274288.

Lundekvam, H., Romstad, E. \& Øygaarden, L. (2003), Agricultural policies in Norway and effects on soil erosion. Environmental Science Policy, vol. 6, pp. 57-67.

Ministry of Agriculture and Forestry (2004), Agricultural Support. (http://www.mmm.fi/english/agriculture /support.htm) (visited 10. July 2005).

Ministry of the Environment (2004), Preparation of Action Plan for the Aquatic Environment III. (http://www.vmp3.dk) (visited 10. July 2005).
Nordisk Ministerråd (2005), Nordic Environmental Action Plan 2005-2008. ANP 2005:714, Copenhagen, pp. 24. Rekolainen, S., Ekholm, P., Ulén, B. \& Gustafson, A. (1997), Phosphorus losses from agriculture to surface waters in the Nordic countries. In: H. Tunney et al. (eds) Phosphorus loss from soil to water. CAB International, Wallingford, pp. 77-94.

Rekolainen, S., Kämäri, J., Hiltunen, M. (2003), A conceptual framework for identifying the need and role of models in the implementation of the Water Framework Direcitve. International Journal of River Basin Management, vol. 1, pp. 165-171.

Schoumans, O.F. \& Silgram, M. (eds.) (2003), Review and Literature Evaluation of Nutrient Quantification Tools. Application and evaluation of phosphorus and nitrogen loss quantification tools. EuroHarp WP 3 and 4. European Commission Framework Programme 5, 122 pp.

Sharpley, A.N., McDowell, R.W., Weld, J.L. \& Kleinman, P. (2001), Assessing site vulnerability to phosphorus loss in an agricultural watershed. Journal of Environmental Quality, vol. 30, pp. 2026-2036.

Sharpley, A.N., Weld, J.L., Beegle, D.B., Kleinman, P.J.A., Gburek, W.J., Moore, P.A. \& Mullins, G. (2003), Development of phosphorus indices for nutrient management planning strategies in the United States. Journal of Soil and Water Conservation, vol. 58(3), pp. 137-152.

State Pollution Control (2005), State of the Environment, Norway. (http://miljostatus.no) (visited 10. July 2005).

Stålnakke, P., Vandsemb, S.M., Vassiljev, A., Grimvall, A. \& Jolankai, G. (2004) Changes in nutrient levels in some Eastern European rivers in response to large-scale changes in agriculture. Water Science and Technology, vol. 49(3), pp. 29-36.

Swedish Environmental Protection Agency (2004), Sweden's environmental objectives, de facto 2004. (http://www.miljomal.nu) (visited 10. July 2005).

Søndergaard, M, Jeppesen, E., Jensen, J.P. (eds.), Bradshaw, E., Skovgaard, H. \& Grünfeld, S. (2003), Vandrammedirektivet og danske søer. Del 1: Søtyper, 
referencetilstand og økologiske kvalitetsklasser. National Environment Research Institute, NERI Report no. 475, 142 pp.

Ulén, B. \& Fölster, J. (2005), Närsaltskoncentrationer och trender i jordbruksdominerade vattendrag. Ekohydrologi 84, Rapport 2005:5 Sveriges Lantbruksuniversitet, 55 pp.

Ulén, B. \& Jakobsson, C. (2005), Critical evalutation of measures to mitigate phosphorus losses from agricultural land to surface waters in Sweden. Science of the Total Environment, vol. 344, pp. 37-50.

Veith, T.L., Sharpley, A.N., Weld, J.L., Gburek, W.J. (2005), Comparison of measured and simulated phosphorus losses with indexed site vulnerability. Transactions of the ASAE, vol. 48, pp. 557-565.

Vuorenmaa, J. Rekolainen, S., Lepistö, A., Kenttämies, K. \& Jauppila, P. (2002), Losses of nitrogen and phosphorus from agricultural and forest areas in Finland during the 1980s and 1990s. Environmental Monitoring \& Asessment, vol. 76(2), pp. 213-248. 



\section{Summaries of the Presentations}

\subsection{What are the implications of the Water Framework Directive for managing agricultural phosphorus?}

\section{Seppo Rekolainen}

Finnish Environment Institute, PO Box 140, Helsinki, Finland seppo.rekolainen@ymparisto.fi

The Water Framework Directive (WFD) of the European Union is a framework for a European environmental legislation that aims to harmonize existing European water policies and to improve water quality in all aquatic environments within the community area. This will be done through a new integrated approach resulting in the protection and improvement of the sustainable use of all waters. Successful transposition and implementation of the WFD is a challenge not only to the governments and competent authorities, but to the research organizations providing the scientific support for the different phases of the implementation as well.

Assessments to guide, support, monitor and evaluate policies, such as the WFD, require scientific approaches, which integrate biophysical and human aspects of ecological systems and their interactions, as outlined by the International Council for Science (2002). These assessments need to proceed from well-developed frameworks rooted in human ecosystem thinking. Amongst other relevant criteria, these frameworks need to reveal different aspects of environmental problems, their causes and remedies, and they should provide a basis for scientific methods needed to analyze them. These frameworks should also recognize linkages between various aspects of the ecological and socio-economic systems. An analysis of these linkages requires development of modelling systems.

The overall WFD implementation process consists of several consecutive steps, and the successful implementation of these steps requires different kinds of decision support tools, such as pollution quantification algorithms, decision support systems, and dynamic simulation models. The use of models as tools in the WFD context has been an issue of discussion and development as described e.g. by Wasson et al. (2003) and Dørge and Windolf (2003). Moreover, Saloranta et al. (2003) have suggested "benchmark criteria” against which the candidate models should 
be exposed to comprehensive testing in order to help water managers and other model users in choosing appropriate models for each WFD implementation purpose. However, there is a lack of understanding on what are the different phases of the WFD implementation, and what types of models, if any, can be used as tools in each of these phases.

One of the fundamental features of the WFD is the introduction of the river basin management planning system. This is a mechanism that ensures integrated management of the aquatic environment, and provides a decision-making framework for setting the environmental objectives. River basin management plans (RBMP) will have to be delivered every six years, with the first deadline in 2009. The RBMPs, which have to be drawn up for river basin districts, consists of four distinct phases: 1) characterization of river basins and assessments of pressures and impacts, 2) environmental monitoring, 3) setting of environmental objectives, and 4) design and implementation of programmes of measures needed to achieve the environmental objectives. The first deadline for achieving the environmental objectives will be in 2015, which is then followed by the 2nd RBMP.

In other words the implementation of the WFD can be seen as a continuous planning process. From this overall process three main phases can be distinguished requiring different approaches for modelling and model applications:

- Formulation of scenarios and setting the objectives: this phase consists of identification and quantification of pressures and impacts being due in 2004; Then the first assessment of water bodies being at risk not achieving the objectives has to be reported in 2004. The ultimate national objectives have to be reported in 2009, but have to be set much earlier, after the inter-calibration exercise in 2006.

- Derivation of measures: in this phase, where an object-oriented management of the water bodies is the aim, it is evaluated what measures are needed in order to achieve the objectives and what are the predicted ecological, social and economic consequences of these policies (ex ante evaluation), due to be reported in the 1st RBMP in 2009.

- Assessment of policies: in this phase it will be evaluated how successful were the measures identified in the 1st RBMP in reaching the objectives. During the years after 2009 new data and information about the socio-economic developments and responses as well as ecosystem behaviour are collected and evaluated (lessons learned, ex post evaluation). The second RBMP is due to be reported in 2015 .

In the recent report by the European Environment Agency (2003), a general trend of decreasing phosphorus has been observed in numerous rivers and lakes in Europe. However, this decrease is mainly due to the improved waste-water treatment; diffuse pollution, particularly from agri- 
culture, has remained high and maintains high phosphorus concentrations in many waters. This fact will emphasize the efforts needed to reduce phosphorus loading particularly from agricultural sources.

The WFD requires Member States to combine their approach for reducing point and diffuse sources (Article 10). More specifically the Directive requires Member States to establish/implement:

- emission controls based on best available techniques

- relevant emission limit values

- in case of diffuse impacts, measures of control including, as appropriate, best environmental practices

The integrated approach calls for tools that are capable of:

- assessing target loads (loads that are sufficiently low in order to reach good ecological status in surface waters);

- apportionment of the nutrient loading between different sources;

- assessing and optimizing the most cost-effective set of abatement measures; and

- assessing, together with empirical monitoring, if the designed and implemented measures will meet the objectives

According to the Annex V of the WFD, operational monitoring has to be established for those water bodies at risk of failing to meet their environmental objectives to assess the changes in the status of such water bodies resulting from the programme of measures. Furthermore, the Annex V sets rules for site selection, specifically for water bodies impacted by diffuse pollution:

- sufficient monitoring stations within a selection of the bodies in order to assess the magnitude and impact of the diffuse source pressures

- selection of bodies shall be made such that they are representative of the relative risks of the occurrence of the diffuse pollution, and representative of the relative risks of the failure to achieve good surface water status

In summary, the WFD requires the setting of objectives for surface waters based on ecological quality elements. In cases where these objectives will not be met, we have to identify the pressures causing the problem, how much these pressures should be reduced, and what is the costeffective way to reach acquired levels. Since agriculture is, in many Member States, and in some of the Accession Countries, one of the major sources of nutrients and the primary cause of eutrophication, much attention has to be paid to assessing the impacts of agriculture and how to reduce them. In this work relevant and suitable tools are required. 


\section{References}

International Council for Science (2002), Making science for sustainable development more policy relevant: New tools for analysis. ICSU Series on Science for Sustainable Development No. 8, 28 pp. Wasson, J.-G., Tusseau-Vuillemin, M.H., Andreassian, V., Perrin, C., Faure, J.-B., Barreteau, O., Bousquet, M. \& Chastan, B. (2003), What kind of water models are needed for the implementation of the European Water Framework Directive? Examples from France. Int. J. River Basin Management, vol. 1, pp. 125-135.

Dørge, J. \& Windolf, J. (2003), Implementation of the water framework di- rective - can we use models as a tool in integrated river basin management? Int. J. River Basin Management, vol. 1, pp. 165-171.

European Environment Agency (2003),

Europe's water: An indicator-based assessment. EEA Topic report No 1/2003. $97 \mathrm{pp}$.

Saloranta, T., Kämäri, J., Rekolainen, S. \& Malve, O. (2003), Benchmark Criteria: A Tool for Selecting Appropriate Models in the Field of Water Management. Environmental Management, vol. 32, pp. 322-333. 


\title{
3.2 Phosphorus Losses in Agricultural Catchments in the Nordic and Baltic region
}

\author{
Nils Vagstad, Hans E. Andersen, Arvo Iital, Viesturs Jansons, Katarina \\ Kyllmar, Seppo Rekolainen, Rimvydas Tumas and Johannes Deelstra ${ }^{2}$
}

\section{Introduction}

The Water Framework Directive (WFD) and the river basin management plan (RBMP) linked to the directive set the scene for the future management of European waters. The ecological status of water bodies shall be maintained and if necessary improved to meet the defined quality targets. In many cases this implies a reduction of the nutrient inputs. The river basin management plan will oblige authorities to establish and initiate measures to ensure that the ecological quality targets can be met. In order to do so, it will be necessary to identify sources and quantify and assess their impacts on the ecological status of individual water bodies. A sufficient understanding of the essential cause-effect relationships, e.g. by linking terrestrial and aquatic processes, is a prerequisite for the pressures and impact analysis and for the establishment of cost-efficient measures. It is obvious that agriculture and in particular the diffuse phosphorus losses will become a major challenge in this context, and furthermore, that adequate data on the agricultural nutrient losses will be of great value for the implementation of the RBMP linked to the WFD.

This paper presents data on observed $\mathrm{P}$ losses from agriculture in the Nordic and Baltic region, based on measurements in small agricultural catchments. The results are briefly discussed with regard to the possible implications for the management strategies (e.g. in relation to quantification of loads and assessment of critical source areas) and the implementation of the WFD.

\section{Database}

Data were collected from a total of 35 small agricultural catchments in Finland, Estonia, Latvia, Lithuania, Sweden, Norway and Denmark. These catchments were selected from the on-going national monitoring programmes on agricultural nutrient losses. The available time series may vary, but this presentation is mainly based on data covering the time period from 1993-1997 with additional data covering the time period up to 2002 for some of these catchments.

\footnotetext{
${ }^{2}$ Nils Vagstad: Norwegian Institute for Water Research; Hans E. Andersen: National Environment Research Institute; Arvo Iital: Tallinn Technical University; Viesturs Jansons: Latvia University of Agriculture; Katarina Kyllmar: Swedish University of Agricultural Sciences; Seppo Rekolainen: Finnish Environment Institute; Rimvydas Tumas: Lithuania University of Agriculture, and; Johannes Deelstra: Norwegian Centre for Soil and Environmental Research
} 
The applied monitoring strategies are different. Some countries applied a system with flow proportional sampling and chemical analysis of composite samples, whereas other countries applied a system based on grab sampling at regular time intervals (e.g. weekly or bi-weekly).

Data on crops and management practices are available in most of the catchments, enabling the analysis of the possible linkages between agricultural practices and nutrient losses.

\section{Catchment characteristics}

The total catchment area is usually less than $20 \mathrm{~km}^{2}$, whereas agricultural land, with a few exceptions, constitutes more than $50 \%$ of the land use. Cereals are the dominant crop in most of the catchments, although root crops, vegetables and/or pastures constitute considerable parts of the land use in some of the catchments. Livestock densities are generally at a moderate level and usually below $1 \mathrm{LU} / \mathrm{ha}$.

Table 1 presents some important characteristics of the catchments, including the $\mathrm{P}$ concentrations at the catchment outlets and estimated soil surface $\mathrm{P}$ balances for the agricultural land.

Table 1. Some characteristics of the 35 catchments included in the study. Figures presented by range of variation

\begin{tabular}{llllll}
\hline $\begin{array}{l}\text { Country and } \\
\text { No of sites }\end{array}$ & $\begin{array}{l}\text { Total area } \\
\mathbf{K m}^{2}\end{array}$ & $\begin{array}{l}\text { Precipitation } \mathbf{P} \text { balance } \\
\mathbf{M m ~} \mathbf{~ r ~}^{-1}\end{array}$ & $\begin{array}{l}\mathbf{P O}_{\mathbf{4}}-\mathbf{P} \\
\mathbf{K g ~ P ~ h a ~}^{-1}\end{array}$ & $\begin{array}{l}\text { Total-P } \\
\mathbf{M g ~ L}^{-1}\end{array}$ \\
\hline Estonia (2) & $9.7-25.5$ & $676-730$ & $\mathrm{X}$ & $0.01-0.16$ & $0.04-0.36$ \\
Finland (4) & $0.12-15.4$ & $513-662$ & $\mathrm{X}$ & $0.01-0.06$ & $0.11-0.68$ \\
Latvia (3) & $3.7-9.6$ & $569-730$ & $-3-+1$ & $0.02-0.19$ & $0.03-0.27$ \\
Lithuania (3) & $1.7-13.6$ & $501-580$ & $-6--1$ & $0.04-0.07$ & $0.07-0.14$ \\
Sweden (10) & $1.9-16.8$ & $477-864$ & $-9-+12$ & $0.05-0.14$ & $0.06-0.28$ \\
Norway (7) & $0.7-20.0$ & $585-1230$ & $+5-+9$ & $0.04-0.06$ & $0.12-0.93$ \\
Denmark (6) & $4.7-11.4$ & $614-993$ & $+3-+13$ & $0.005-0.1$ & $0.07-0.23$ \\
\hline
\end{tabular}

\section{Mean P losses during 1993-1997}

Figure 1 presents the measured mean $\mathrm{P}$ losses in the 35 study catchments during the time period from 1993-97. Results are presented by unit area of agricultural land, corrected for the assumed contribution from nonagricultural land.

Results show tremendous variability, with an overall range in $\mathrm{P}$ losses from less than 0.1 to almost $5 \mathrm{~kg} \mathrm{P}^{-1}$ (total-P) during the five-year period. The observed P losses in the Norwegian catchments are generally higher than those observed in the other countries, although substantial variations occur between the different catchments. The possible explanations are not straightforward, although some of the cases might be explained by high levels of erosion and a relatively high portion of overland flow in most of the Norwegian catchments. As for the Danish catchments, the base flow component constitutes a considerable part of the total run- 
off, which often implies a lower level and less variability in P losses than in cases where surface runoff and preferential flow are more important pathways for nutrient transfer. However, as indicated in table 2 (next paragraph), the annual variability appears at least as high in the Danish catchments as in the Norwegian catchments.

The fractions of $\mathrm{PO}_{4}-\mathrm{P}$ of the total $\mathrm{P}$ losses are highly variable from one catchment to another, ranging from less than $10 \%$ to more than 90 $\%$. This indicates substantial variations in terms of possible biological impacts in receiving waters. In this respect it is also worth mentioning that the N/P-ratio varied from around 10 to 300 (data not shown here), bearing in mind the possible linkages between nutrient compositions and algal community development in surface waters.

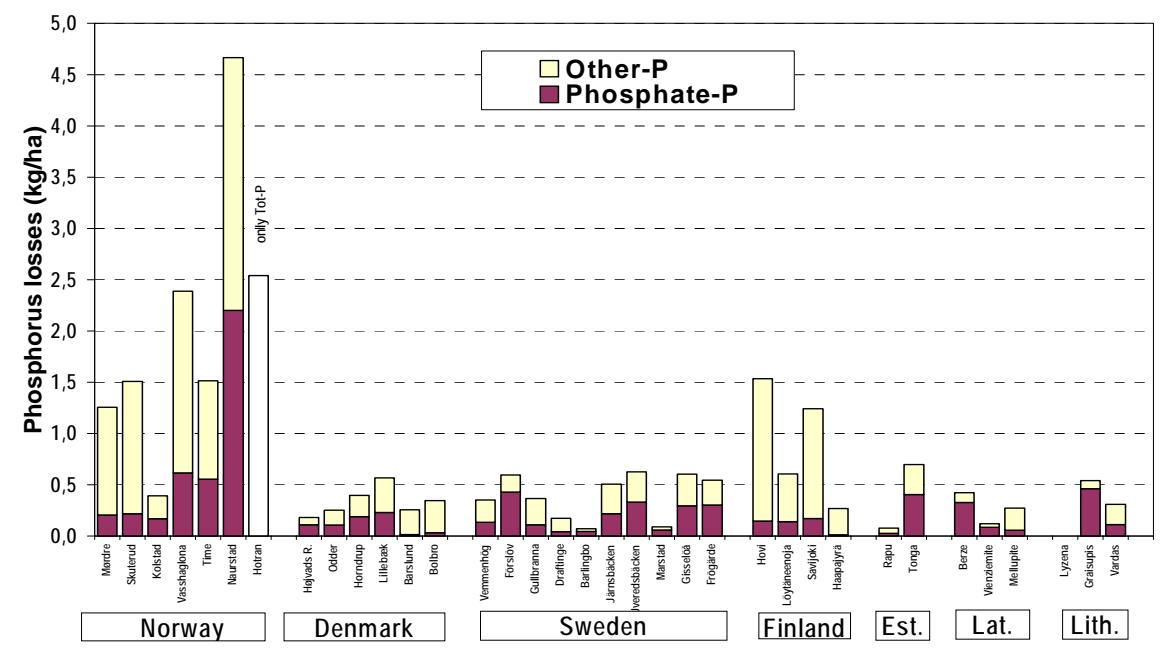

Figure 1. Measured $\mathrm{P}$ losses (Total $\mathrm{P}$ and $\mathrm{PO}_{4}-\mathrm{P}$ ) in 35 small agricultural catchments in the Nordic-Baltic region. Figures represent mean losses during 1993-1997 in $\mathrm{kg} \mathrm{ha}^{-1}$ agricultural land. Data based on Vagstad et al. (2001)

\section{Annual variations in $P$ losses}

In addition to the large spatial variability, the results also show remarkably high temporal variability (seasonal and annual). Table 2 presents examples of the annual variability in P losses during the time period 19932002 in a selected number of catchments where cereals represent the predominant crop. 
Table 2. Different variability indicators of the $P$ losses in a selected number of catchments in Norway, Denmark, Sweden and Latvia. Based on data from the time period 1993-2002 (10 years)

\begin{tabular}{lrrrrr}
\hline Catchment & $\begin{array}{l}\text { Mean } \\
\text { Kg ha }^{-1}\end{array}$ & $\begin{array}{l}\text { Min } \\
\text { Kg ha }^{-1}\end{array}$ & $\begin{array}{l}\text { Max } \\
\text { Kg ha }^{-1}\end{array}$ & \multicolumn{1}{l}{$\begin{array}{l}\text { Min/max } \\
\text { ratio }\end{array}$} & CV \\
\hline Horndrup (DK) & 0.48 & 0.15 & 0.96 & 6.4 & 0.47 \\
Lillebæk (DK) & 0.63 & 0.16 & 0.71 & 7.2 & 0.48 \\
Højvands R (DK) & 0.21 & 0.03 & 1.15 & 15.7 & 0.62 \\
\hline Mellupite (LV & 0.17 & 0.09 & 0.27 & 3.0 & 0.43 \\
Berze (LV) & 0.31 & 0.12 & 0.52 & 4.2 & 0.46 \\
\hline Mørdre (N) & 1.59 & 0.89 & 3.96 & 4.4 & 0.54 \\
Skuterud (N) & 2.58 & 0.92 & 5.88 & 6.4 & 0.62 \\
Kolstad (N) & 0.56 & 0.21 & 1.26 & 6.0 & 0.63 \\
\hline Ulverød (S) & 0.94 & 0.40 & 2.30 & 5.8 & 0.61 \\
Marstad (S) & 0.12 & 0.09 & 0.16 & 1.8 & 0.33 \\
Gisseløå (S) & 0.51 & 0.33 & 0.82 & 2.5 & 0.41 \\
\hline
\end{tabular}

Results show that the ratio between the highest and the lowest observed annual P losses of the individual catchments ranges from approximately 2 - 15 during the ten-year measurement period.

As mentioned earlier, the explanation of the observed variation in $\mathrm{P}$ losses is not straightforward, although runoff seems to be an important explanatory factor. This is illustrated in figure 2, which presents the relations between annual runoff and annual P losses in the Skuterud catchment in Norway.

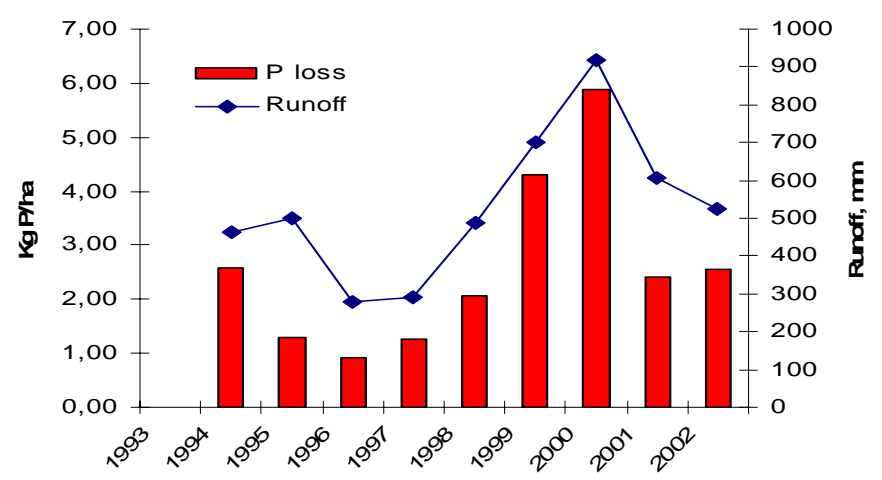

Figure 2. Annual $P$ losses in the Skuterud catchment (Norway) versus annual runoff

$\mathrm{P}$ balances are frequently used as indicators of water quality impacts related to agriculture, e.g. by the OECD. However, this study did not reveal any good and general correlations between measured P losses and calculated soil surface. This result is probably not surprising, bearing in mind the type of processes determining the P losses at catchment scale. 


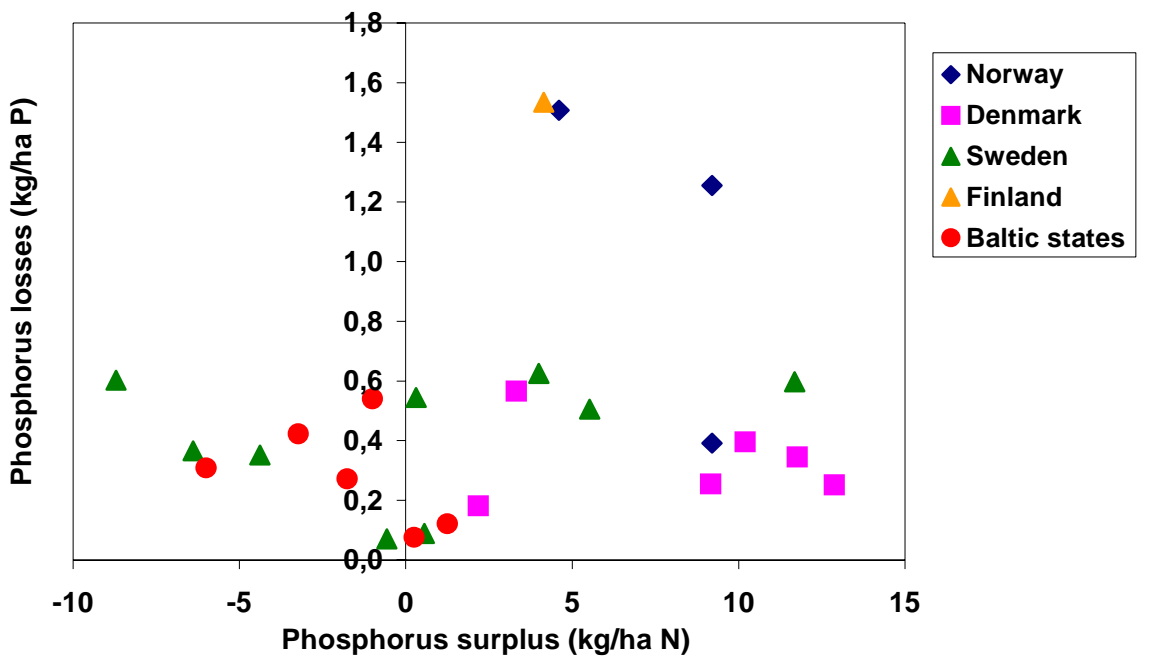

Figure 3. Relations between measured $P$ losses (1993-1997) and soil surface $P$ balances in the 35 study catchments. Based on Vagstad et al., 2001

\section{Policy implications/linkages}

Eutrophication is still one of the main problems in European waters. Moreover, the relative importance of diffuse $\mathrm{P}$ losses from agriculture is increasing due to improvements made to reduce point sources emissions. Thus, efficient strategies to control the P losses from agriculture are likely to become one of the key issues in the implementation of the RBMP linked to the WFD. The current monitoring programmes can, if utilised properly, provide important support for the assessments that need to be undertaken during the implementation of the WFD, both at local, regional and at European level. Two contrasting directions can be foreseen, i.e. the need for harmonisation and standardisation at European level versus the need for precision and site-specific approaches at local and regional level. Practical solutions in the form quantification and assessment tools that integrate both aspects should be developed, although this is obviously not a straightforward task. The monitoring programmes may contribute to the development of such tools.

The results from the current monitoring programmes provide at least four essential messages that may influence the management approaches and strategies;

- P losses may vary greatly from one area to another

- Adequate methods to identify high-risk areas can be essential in order to meet the requirements of the WFD, in particular to ensure that resources to control the losses are spent in a cost-efficient way

- There are very large temporal variations in P losses, both within and between years 
- Trend analysis should be interpreted with great caution to avoid biased conclusions. Methods to distinguish the anthropogenic effects from natural causes should be given priority

- The bio-available part of the P losses seems to vary greatly

- The WFD is impact- and action oriented. Methods enabling a more precise characterisation and assessment of the site-specific and potential ecological impacts of the $\mathrm{P}$ losses should be given priority. This will ensure more targeted approaches in order reduce the impacts of agricultural $\mathrm{P}$ losses

- The variations are not easily explained

- Everybody involved in this has to do their best to release sufficient funding for P research. Soil scientists and hydrologists need to work more closely with limnologists in order to ensure that monitoring programmes are well targeted and to ensure a sound scientific basis for the forthcoming river basin management plans.

\section{References}

Vagstad, N., Stålnacke, P., Andersen, H.E., Deelstra, J., Gustavson, A., Iital, A., Jansons, V., Kyllmar, K., Loigu, E., Rekolainen, S. \& Vouorenmaa, J.
(2001), Nutrient losses from Agriculture in the Nordic and Baltic Regiona. Tema Nord Report 2001:591. 


\title{
3.3 Strengths and weaknesses of phosphorus models: EUROHARP. Short summary
}

\author{
Oscar Schoumans \\ Alterra, Wageningen University and Research Centre, The Netherlands
}

\section{Introduction}

One of the major aims of the EU-project EUROHARP is to determine the performance and potential capability of different types of quantification tools by means of a scientific evaluation and a 'practical' test that compares the results of the quantification tools with the measured data of three core catchments. An a priori scientific evaluation of the broad approaches used in each model is important because many factors determine the phosphorus and nitrogen loss from agricultural land to surface waters and therefore end-users should be aware of the potential limitations of each quantification tool. Furthermore, most quantification tools are used to predict the effect of practical management measures on nutrient losses (scenario analysis), e.g. manure management strategies, land use changes and water management strategies. The final scientific evaluation of the actual performance of each model will be made in later stages of the EUROHARP project once each model has been applied to each of the three "core" catchments and the statistical performance criteria have been calculated. The major aim of work carried out in 2002 and 2003 was to describe, compare and evaluate, in a comprehensive scientific way, the quantification tools with are used within the EUROHARP project in order to provide end-users with objective information on the quality and applicability of the quantification tools.

\section{Quantification tools}

Several different types of quantification tools for nutrient losses to river basins have been developed during the last decade within European countries. These different approaches were established for different climatic regions and for different tasks (e.g. coarse "screening" tool for identifying high risk areas or detailed scenario tool for exploring management options), and they vary in their complexity, their resolution in time and space, and their input data requirements (Figure 1). 


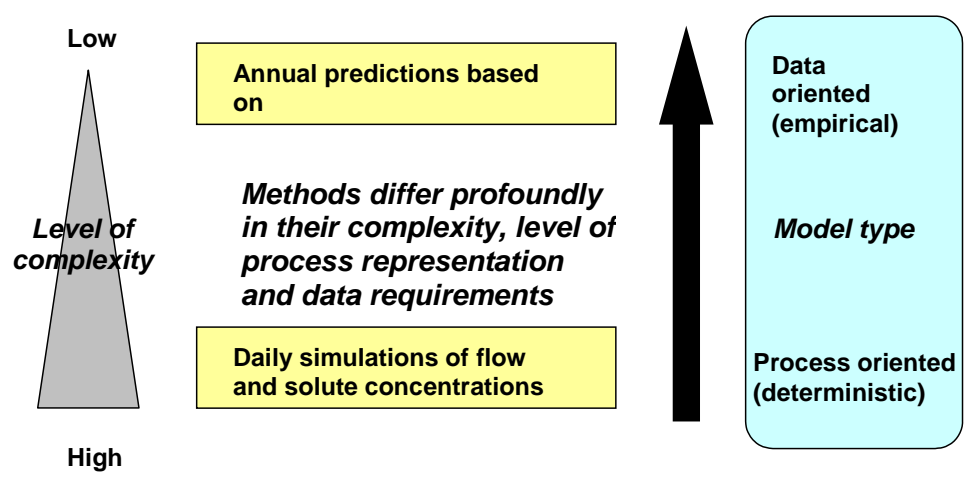

Figure 1. A general relation between the complexity of models (left), model type (right) and the generated output (Schoumans and Silgram, 2003)

The quantification tools used within this study (Table 1) range from spatially lumped static quantification tools to fully distributed processorientated dynamic quantification tools. These approaches are examples of different generic contemporary modelling solutions, which can be used to predict nutrient pollution at catchment scale. Moreover, many quantification tools have only been applied within a relatively narrow climatic range of catchments in Europe, and may need development or modification before they can respond to gradients in climate (e.g. frozen soils, water stress, temperature impacts on plant growth and soil nutrient cycling), hydrology (e.g. shallow groundwater), land use (new crop types) and/or agricultural practices in other parts of Europe. Problems with the acquisition of specific input data to the different models can also severely limit their application to different parts of Europe.

Table 1 Quantification tools (QT)

\begin{tabular}{llll}
\hline No. & Name of the tool & $\begin{array}{l}\text { Nitogen (N) } \\
\text { and/or } \\
\text { Phosphorus } \\
\text { (P) model }\end{array}$ \\
\hline 1 & NL-CAT & N, P & ANIMO: Groenendijk and Kroes (1999). \\
& (ANIMO / SWAP & & SWAP: Van Dam (2000) \\
& $\&$ & & SWQN: Rijtema et al. (1991). \\
& SWQN / SWQL) & & SWQL: Van der Kolk and Drent (1996). \\
\hline 2 & REALTA & P & Kirk McClure Morton (2001). \\
\hline 3 & N-LES CAT & $\mathrm{N}$ & Simmelsgaard et al. (2000). \\
\hline 4 & MONERIS & $\mathrm{N}, \mathrm{P}$ & Behrendt et al. (1999) \\
\hline 5 & TRK & $\mathrm{N}, \mathrm{P}$ & SOILNDB \& SOILN: Johnsson et al. 2002) \\
& (SOILNDB / & & HBV: Bergström (1995). \\
& HBV-N) & & HBV-N: Pettersson et al. (2001). \\
& & & TRK: Swedish EPA (1997) \\
\hline 6 & SWAT & $\mathrm{N}, \mathrm{P}$ & Neitsch et al. (2001). \\
\hline 7 & EveNFlow & $\mathrm{N}$ & Anthony et al. (1996), Lord \& Anthony (2000) \\
\hline 8 & NOPOLU & $\mathrm{N}, \mathrm{P}$ & European Environment Agency/IFEN (2000). \\
\hline 9 & Source & $\mathrm{N}, \mathrm{P}$ & OSPAR 00/9/2 Add.8 and OSPAR 00/20/1, \\
& apportionment & & § 9.5a \\
\hline
\end{tabular}

1) Complete list of References of each model/module: Annex B in Schoumans and Silgram (2003) 


\section{Intercomparison}

For the a priori intercomparison of the quantification tools fifteen different assessment criteria were considered (Schoumans and Silgram, 2003), including: (1) Original purpose/status and history of the model (maturity), (2) Dependencies on previous models (scientific evolution), (3) Review of pathways and processes described by the quantification tools, (4) Scientific description of the processes involved, (5) Spatial resolution and discretisation (horizontal and vertical), (6) Temporal resolution and discretisation, (7) Forms of nutrient losses described by the quantification tool, (8) Data requirements, (9) Operational experience and skills requirement of users, (10) Participation in previous model comparison studies, (11) Sub-modules that can be independently checked, (12) Existing sensitivity analysis, (13) Cost indication (based on work load to set up and apply the quantification tool), (14) Capability to evaluate nutrient and watershed management strategies (scenario analysis) and (15) Applicability to different catchment typologies (climate, land use, hydrology, etc). Finally, the results of a scientific intercomparison include also an analysis of potential strengths and weaknesses of the nutrient quantification tools.

All modelling institutes participating in the EUROHARP project were involved in considering the different models according to these criteria, and the conclusions have been discussed in several project workshops. The synthesis of this a priori assessment is presented in some tables (Schoumans and Silgram, 2004).

Although the costs of applying the quantification tools differ substantially, the most suitable model for a particular application will depend on the purpose of the study (e.g. identifying risk areas, detailed quantification of partitioning of losses from land, scenario analysis for mitigation options etc.) and the quality (accuracy and precision) needed from model results ("cost-effectiveness"). A comparison of costs of application against model performance will be possible once the model applications have been completed and performance assessed on several European catchments.

Based on this initial a priori overview, it is clear that all of the models have some potential limitations with respect to their suitability for application to all European catchments with their specific soils, land use, climate, and hydrological conditions. In summary, this review has demonstrated that the EUROHARP quantification tools differ profoundly in their approach to predict the diffuse nutrient losses from agricultural land to surface freshwater systems. This is a reflection of differences in (i) their level of complexity, (ii) their representation of system processes and pathways, and (iii) their resource (data and time) requirements. The quantification tools range from complex, process-based models - which typically have demanding data requirements - to semi-empirical (conceptual) meta-models with some export coefficients, and approaches based on mineral balances and source apportionment. These differences between 
modelling approaches are also a result of the original purpose associated with model development i.e. some models were intended as catchment scale screening tools, some for more detailed policy support work (such as pressure/impact assessments), and some were developed from detailed field-scale models with a highly complex representation of soil-plant system processes.

The final selection of a particular model for a particular catchment will depend on the question being asked, the data availability, the resource limitations, and the physical characteristics of the catchment in question (which limit the suitability of some models).

This review document - the first EUROHARP report - is intended as an initial overview of different model approaches. The report has highlighted the main approaches used in each modelling tool, including the representation of hydrological and plant-soil processes. This in itself has improved the transparency associated with the modelling exercise. Equally importantly, some initial views have been collated concerning the potential strengths and weaknesses of each approach, and the precise temporal and spatial range of each model have been noted.

The next stage of EUROHARP involves the actual assessment of the performance of each model on each of the three core catchments. These results, which will be produced during 2004 and 2005 and which will be presented in a future report, will allow the performance of each model to be compared across the different catchment types, and also permit the ranking of all models on the same catchments. The final output from the project will include a EUROHARP toolbox, summarizing all results and implications in a user-friendly interface to assist end-users in the selection of appropriate models for use in particular catchment typologies for a range of policy evaluation and assessment purposes.

\section{Conclusions}

- The available nutrient loss quantification tools studied in this project vary widely in their complexity, degree of process representation, input data requirements, and temporal/spatial resolution

- It is therefore not possible to determine, a priori, the most suitable model for a particular application, although some broad recommendations are possible based on: (1) The precise aim of the study; (2) The acknowledged limitations of specific model formulations; (3) The quality, availability, timestep and record length of datasets needed for model parameterisation and performance assessment; (4) Whether scenario analyses are required

- Further results during 2004 will provide an indication of the merits of the other eight different modelling approaches in estimating diffuse $\mathrm{N}$ and P losses to freshwater systems in Norway, England, and Italy and 
an application of the quantification tools on at least three other catchments. These results will be reported in a future paper.

- Based on the approach set up within the EUROHARP project it is possible to evaluate also other quantification tools by describing them in terms of the criteria set up in the model review document. From this perspective nutrient quantifications tools can be "registered" and become part of the EUROHARP Toolbox that will developed within EUOHARP.

\section{Epilogue}

The results of the models on the Norwegian Catchments are still under construction and therefore, not presented in this short summary. Nevertheless, during the presentation at the Nordic Workshop "Tools for assessing Phosphorus Loss from Nordic Agriculture” some preliminary/ temporary results will be shown of the available data.

\section{References}

Anthony, S.G., Quinn, P. \& Lord, E.I. (1996), Catchment scale modelling of nitrate. Aspects of Applied Biology, vol. 46, pp. 23-32.

Behrendt, H., Huber, P., Ley, M., Opitz, D., Schmoll, O., Scholz, G. \& Uebe, R. (1999), Nährstoff-bilanzierung der Flußgebiete Deutschlands. UBA-texte, 75/99, Berlin, 288 pp.

Bergström, S. (1995), The HBV model. In: Singh, V.P. (ed.). Computer Models of Watershed Hydrology, Water Resources Publications, Littleton, Colorado, pp. 443-476.

Borgvang, S-A. \& Selvik, J.S. (eds.) (2000), Development of HARP Guidelines - Harmonised Quantification and Reporting Procedure for Nutrients. SFT Report 1759/2000. ISBN 82-7655-4016. 179 pp.

Dam, J.C. van (2000), Field-scale water flow and solute transport. SWAP model concepts, parameter estimation and case studies. Ph.D.-thesis, Wageningen University, Wageningen.

European Environment Agency/IFEN (2000), Calculation of nutriment surplus from agricultural sources. Statistics spatialisation by means of CORINE land cover. Application to the case of Nitrogen. Technical report No 51, EEA Copenhagen, $62 \mathrm{pp}$.
Groenendijk, P. \& Kroes, J.G. (1999), Modelling the nitrogen and phosphorus leaching to groundwater and surface water with ANIMO 3.5. Winand Staring Centre, Wageningen. Report 144. Johnsson, H., Larsson, M., Mårtensson, K. \& Hoffmann, M. (2002), SOILNDB: A decision support tool for assessing nitrogen leaching losses from arable land. Environmental Modelling \& Software, vol. 17, pp. 505-517.

Kirk McClure Morton Ltd (2001), The Lough Derg and Lough Ree Catchment Monitoring and Management System. Final Report, Belfast. 223 pp.

Kolk, J.W.H. van der \& Drent, J. (1996), NUSWA - a mathematical model to predict the fate of nutrients in surface water systems. DLO-Winand Staring Centre, Wageningen. Internal Report 402.

OSPAR (2000), Guideline 8: Principles for Source Apportionment for Quantifying Nitrogen and Phosphorus Discharges and Losses. Reference Number: 2000-1; 00/9/2 Add.8 and 00/20/1, § 9.5a.

Rijtema, P.E., Smit, M.F.R., Boels, D., Abdel Gawad, S.T. \& El Quosy, D.E. (1991), Formulation of the Water Distribution Model WATDIS. Reuse of Drainage Water Project Report 23. Drainage Research Institute, Cairo, 
Egypt and The Winand Staring Centre, Wageningen, The Netherlands Schoumans, O.F. \& Silgram, M. (eds.) (2003), Review and Literature Evaluation of Nutrient Quantification Tools. Application and evaluation of phosphorus and nitrogen loss quantification tools. EuroHarp WP 3 and 4. European
Commission Framework Programme 5, 122 pp.

Simmelsgaard, S.E., Kristensen, K., Andersen, H.E., Grant, R., Jørgensen, J.O. \& Østergaard, H.S. (2000), An empirical model for calculation of root zone nitrate leaching. DJF rapport Markbrug no. 32, 67 pp. (in Danish). 


\title{
3.4 An Evaluation of Models to Assess the Risk of Phosphorus Loss from Agricultural Land to Water
}

\author{
Louise Heathwaite \\ Department of Geography, University of Sheffield, Sheffield, S10 2TN, UK, \\ louise.heathwaite@lancs.ac.uk
}

\section{Introduction}

In much of Europe, increased inputs of nitrogen $(\mathrm{N})$ and phosphorus $(\mathrm{P})$ to land in the form of fertilisers, manures and biosolids means that agricultural runoff now comprises a greater share of these nutrients in rivers and lakes and associated water quality problems. While numerous sitespecific field studies have quantified the potential export of nutrients in agricultural runoff, it is clear that to meet the requirements of end-users, the research effort needs to shift towards developing generic models of diffuse source pollutant export from land that are based on expert knowledge but remain simple to use and easy to apply. The urgent need for such models is driven by the EU Water Framework Directive (WFD), which is the most significant piece of European water legislation for over twenty years. Its implementation sets a challenging timetable for delivering the Directive's requirements, in particular the establishment of targeted measures for the control of P losses from agricultural land to water. The scope of the Directive mean that simple instruments are needed to both assess the risk of $\mathrm{P}$ loss from land and to aid the planning of mitigation measures to reduce this risk. This paper reviews some of the available approaches to predict the risk of P loss from agricultural land to water based on current understanding of relevant processes

\section{Background: Risk Assessment Tools}

Research on diffuse pollution has commonly taken one of two routes: (1) small-scale process studies conducted at the lysimeter, field plot or small catchment scale (up to $1 \mathrm{~km}^{2}$ ), and (2) deterministic, physically-based process models. Empirical research has made some inroads in understanding the mechanisms of nutrient transport and delivery from diffuse sources to receiving waters. However, the temporal and spatial complexity of diffuse catchment sources means it is difficult to see how mitigation can be developed strategically without recourse to predictive models.

Diffuse pollution modelling requires accurate and sensitive treatment of spatial data. The spatial variations in catchment characteristics may be modelled using lumped, distributed or topological representations. The extent to which models based on any of these representations may be validated depends on the quality of the available data, with distributed models requiring detailed field data to accurately capture the true varia- 
tion in the catchment, while lumped approaches assume the point scale collection of catchment data are representative of internal catchment processes which are not calibrated. Topological representations of catchment hydrology are becoming more popular through the construction of GIS-based models of catchment structure and function for use as decision support systems for catchment management (e.g. Viney et al. 2000; Cassell et al. 2001). More recently, the topological approach has been applied to diffuse nutrient pollution in the form of the Phosphorus Indicators Tool (PIT; Heathwaite et al. 2003). Simple models such as PIT reflect new directions in diffuse nutrient modelling research, where there is a move from sophisticated, data-demanding models towards simple models that estimate nutrient loss on the basis of the limited data available. Such models commonly operate with a spatial resolution around $1 \mathrm{~km}$ and are driven by data availability, which in most developed countries includes land cover, livestock numbers, crops grown, climate, and physical properties of soils. Below a number of simple modelling approaches that predict diffuse $\mathrm{P}$ losses from land to water are examined.

\section{A: Field-scale Risk Assessment Tools}

\section{Export Coefficient Models including the P Index System}

Empirical nutrient export models may be used to develop indicators of diffuse nutrient pressures at the small catchment through to regional or national scale. The export coefficient model calculates the mean annual total $\mathrm{N}$ and total $\mathrm{P}$ loading $\left(\mathrm{kg} \mathrm{a}^{-1}\right)$ delivered to a surface water body (lake or river) as the sum of the nutrient loads exported from each nutrient source in the catchment. These so-called 'black-box' models have long been used to provide simple budgets of nutrient loads entering water bodies. Such models make no attempt to explain the processes involved in generating nutrient outputs from a set of input parameters but allow some evaluation of the impact of changing inputs or managing outputs within, for example, agricultural systems.

Existing empirical modelling approaches used in the UK include the simple but well-tested Export Coefficient Model (Johnes, 1996; Johnes and Heathwaite, 1997), which has an implicit water quality bias and the P-Expert System (Fraser and Harrod, 1998), which has a soils bias but includes hydrological drivers. In the US, the modified P Index (Gburek et al. 2000) has been refined for use in a number of states where legislation relating to livestock production requires nutrient management planning for P (Weld and Beegle 2001). Heathwaite et al. (2000) describe an integrated N and P Index based on US research. The P Index system is discussed further by Beegle (this issue). 


\section{The Nutrient Export Risk Matrix (The NERM)}

The UK Water Code (MAFF, 1998) identifies soils at risk from P loss where total $\mathrm{P}$ inputs in organic manures, fertilisers and biosolids exceed crop uptake, based on soil test P (MAFF, 2000). The Nutrient Export Risk Matrix (The NERM) is an example of decision support frameworks that are currently being developed in the UK to assess $\mathrm{P}$ loss risk. The NERM has been designed specifically to aid the strategic placement of $\mathrm{P}$ applications derived from biosolids in a spatially sensitive manner, but the same principles apply for the application of manures and fertilisers (Heathwaite et al., 2001). The objectives of the decision support framework used in the NERM are it must be: (1) practical, applicable and usable, (2) based on sound science, (3) a tangible risk management tool for end users, (4) available on the web (or similar), (5) accommodate a P export philosophy that states: "where you are now in the matrix is not where you should stay", and (6) target critical source areas (CSAs) and flow paths for active interception and/or remediation. The NERM is based on evidence that suggests that a small proportion of the watershed may contribute a large proportion of the loss (Gburek et al., 2000; Heathwaite et al., 2000). It uses quantitative evidence for $\mathrm{P}$ loss processes from land (e.g. Heathwaite and Dils, 2000) combined with the interpretation of information regarding local soil processes, historical evidence of $\mathrm{P}$ loss, local topographic controls on hydrological flow paths, and current farmer practices that may exacerbate the P loss (through land drainage, ditching and surface flow along tyre tracks and tramlines) that really allows us to assess the realistic P loss risk.. The NERM is presented as a simple 3-dimensional (3-D) matrix that allows a rough estimate of the $\mathrm{P}$ loss risk for any site and the uncertainty of that estimate. This estimate is combined with an evaluation of the likely impacts of a range of land use management options, i.e. in the control of P surplus and the connectivity of that $\mathrm{P}$ surplus to the receiving waters (Heathwaite et al., 2003a; Heathwaite et al., in review).

\section{B: Catchment-scale Risk Assessment Tools}

1. The Environment Agency Pressure-delivery risk screening matrix (PDRS)

This approach, developed by the UK Environment Agency and the University of Sheffield, assesses the pressure on surface waters from agricultural sources of $\mathrm{P}$ with respect to the WFD. It is more sophisticated than export coefficient modelling, but less sophisticated than the PIT model (see later). The PDRS will be used in the first Pressures and Impact Analysis for river basins which the EU requires member states to complete by the end of 2004. Because of the tight timescale, this approach needs to use currently available data and/or models and must be applicable to all river basins. The method is currently in draft format, and details 
of the approach, such as the boundaries between high medium and low pressure categories may change during the validation of the method.

The PDRS approach is based on a conceptual model for surface waters that links: (1) the pressure from $P$ applied to land as inorganic fertilisers or organic manures, and (2) the likelihood of $\mathrm{P}$ reaching watercourses attached to sediment particles. These are combined using a pressure matrix to give a final pressure map which assigns a High, Medium or Low diffuse $\mathrm{P}$ pressure to a grid square. The pressure maps are currently based on a $1 \mathrm{~km}^{2}$ grid. The surface waters conceptual model is linked to a groundwater model to provide a means of accounting for P delivery to water in groundwater-driven river basins in the England and Wales. The groundwater model uses the Base Flow Index (BFI) to represent areas where there is a high degree of connectivity between the surface and groundwater, and where surface waterbodies are highly influenced by the quality of the groundwater. The approach is described in detail in Carvalho et al. (2003).

\section{The Phosphorus Indicators Tool (PIT)}

The PIT model uses a simple lumped/semi-distributed approach on an annual time-step. It is designed to have low data requirements and is applicable at national, regional and catchment scales. The model prototype is described in Heathwaite et al. (2003b). PIT has a three layer structure with each layer containing a set of parameters that act as the most sensitive indicators for that model layer. Layer 1 (P Source) calculates the soil $\mathrm{P}$ store and additions of $\mathrm{P}$ to land from fertilizers and livestock waste and estimates their potential for loss. The mobilisation of $\mathrm{P}$ from the Layer 1 store by solubilisation and detachment is accounted for in Layer 2 (P Transfer). Finally, Layer 3 (P Delivery) routes and delivers mobilised P along hydrological pathways to watercourses. Included in Layer 3 were infrastructure features such as farm tracks and roads that may result in rapid delivery of $\mathrm{P}$ to water. The model carries out all calculations for cells of $1 \mathrm{~km}$; the results are then summed to give an annual catchment total. The unit of measurement is kg total P per unit area. To retain simplicity, the model is not fully-distributed; there is no explicit connectivity between cells but Layer 2 is used to partition flow, and work in this project is improving the connectivity in Layer 3 to deliver $P$ to water.

The PIT model uses 3 data sources: data to derive the coefficients (plot to field scale); data to drive the model (e.g. MAGPIE or agricultural census data); and water quality data to test the model (Environment Agency or research catchments). The model is written in ArcGIS using the VBA programming language. Excel files containing the input data for the model are directly converted into ArcGIS grid. In the UK, the PIT model is used to support DEFRA policy by identifying those regions at risk of diffuse $P$ pollution from agricultural land so that subsequent finescale modelling and empirical research may be better focused in these 
areas in order to gain added-value from the research and mitigation investment. The challenge with models such as PIT is keeping the model simple and flexible so that it can operate as a screening tool for DEFRA while at the same time acknowledging the complexity of the drivers of diffuse pollution in the landscape.

\section{Some Issues for Discussion in Relation to Risk Assessment Tools}

1. Scaling. We need to develop tools to allow the application of our understanding of small-scale processes to patterns of nutrient loss at the farm or catchment scale because it is at the larger scale that nutrient management strategies are applied and legislation invoked. There is much work still to be done in understanding how to implement this scaling process.

2. Meeting the needs of end-users. End-users of predictive nutrient models include Government agencies, landowners and managers and conservation bodies. The instruments of mitigation available to end-users dealing with diffuse nutrient export from land are blunt. By contrast, some research models are often too complex and/or cost and time-demanding to be widely applicable and readily used. Clearly there is a role here for simple, empirical models but such models must be used carefully and the problem they are being used to address must be well-defined at the outset. 3. The need for a holistic approach to diffuse pollution is implicit in the WFD, and requires integrated nutrient management strategies that are applicable at the river basin scale. Such strategies need to operate within the controls imposed on end-users by legislation, which is often targeted at the quality of receiving waters. There is still much to learn about making holistic approaches work in practice.

\section{Future Developments}

Evaluating nutrient loss from diffuse sources is complex. For $\mathrm{P}$, it is unlikely that a single indicator or set of indicators will be sufficient to accurately predict export from land to water. Risk assessment tools such as PIT constitute fairly sophisticated black-box approaches to diffuse pollution modelling that are able to make good use of expert knowledge and spatial data. The danger lies in extrapolating these simple models beyond their (limited) powers and the difficulty is in recognising their errors and limitations. Simple empirical models cannot, for example, quantify environmental impact because they are not dynamic and can only predict potential loss of diffuse contaminants to water, which is an indirect measure. At present, existing coefficient-based models cannot distinguish the relative importance of different transport or delivery pathways, which remains a critical diffuse pollution research issue. 


\section{References}

Cassell, E.A., Kort, R.L., Meals, D.W., Aschmann, S.G., Dorioz, J.M. \& Anderson, D.P. (2001), Dynamic phosphorus mass balance modelling of large watersheds: long-term implications of management strategies. Water Science and Technology, vol. 43, pp. 153-162.

Edwards, A.C., Heathwaite, A.L. \& Dils, R.M. (2001), The Environmental and Economic Impacts of Diffuse Pollution in the UK: Nitrogen. In: D’Arcy, B.J., Ellis, J.B., Ferrier, R.C., Jenkins, A. \& Dils, R.M. (eds.). Diffuse Pollution Impacts, CIWEM, Terence Dalton Publishers, UK, pp. 61-71.

Fraser, A.I. \& Harrod, T.R. (1998), A systematic approach to predict phosphorus transfer from agriculture using GIS, Proceedings of the Practical and Innovative Measures for the Control of Agricultural Phosphorus Losses to Water. OECD-sponsored workshop, Greenmount College of Agriculture and Horticulture, Northern Ireland, June 1998, pp. 182-183.

Gburek, W.J., Sharpley, AS.N., Heathwaite, A.L. \& Folmar, G. (2000), Phosphorus management at the watershed scale. Journal of Environmental Quality, vol. 29, pp. 130-144.

Heathwaite, A.L. \& Dils, R.M. (2000), Characterising phosphorus loss in surface and subsurface hydrological pathways. Science of the Total Environment, vol. 251/252, pp. 523-538.

Heathwaite, A.L., Sharpley, A. \& Gburek, W. (2000), A conceptual approach for integrating phosphorus and nitrogen management at watershed scales. Journal of Environmental Quality, vol. 29, pp. 158-166.

Heathwaite, A.L., Burke, S.B., Quinn, P.F., Merrett, S.P., Saul, A.J., Lerner, D.N., Whitehead, P.G. \& Preedy, N.P. (2001), Evaluating the environmental risk of sewage sludge recycling the agricultural land: the SEAL project. International Phosphorus Transfer Workshop (IPTW) 2001: Connecting Phosphorus Transfer from Agriculture to
Impacts in Surface Waters, 28 August to 01 September 2001, Plymouth, Devon, England.

Heathwaite, A.L., Burke, S. \& Quinn, P.F. (2003a), The nutrient export risk matrix (the NERM) for strategic application of biosolids to agricultural land. International Association for Hydrological Sciences Publication, vol. 285, pp. 1-9.

Heathwaite, A.L., Fraser, A.I., Johnes, P.J., Hutchins, M., Lord, E. \& Butterfield, D. (2003b), The phosphorus indicators tool: a simple model of diffuse $P$ loss from agriculture land to water. Soil Use and Management, vol. 19, pp. 1-11. Heathwaite, A.L., Quinn, P.F. \& Hewett, C.J.M. (2005), Modelling and managing critical source areas of diffuse pollution from agricultural land by simulating hillslope flow connectivity. Journal of Hydrology, vol. 304, pp. 446-461.

Johnes, P.J. (1996), Evaluation and management of the impact of land use change on the nitrogen and phosphorus load delivered to surface waters: the export coefficient modelling approach. Journal of Hydrology, vol. 183, pp. 323-349.

Johnes, P.J. \& Heathwaite, A.L. (1997), Modelling the impact on water quality of land use change in agricultural catchments. Hydrological Processes, vol. 11, pp. 269-286.

MAFF (1998), The Water Code: Code of Good Agricultural Practice for the Protection of Water. MAFF Publications, London, $97 \mathrm{pp}$.

MAFF (2000), Fertiliser Recommendations for Agricultural and Horticultural Crops. MAFF Reference Book 209, The Stationary Office ISBN 0112429351.

Viney, N.R., Sivapalan, M. \& Deeley, D. (2000), A conceptual model of nutrient mobilisation and transport applicable at large catchment scales. Journal of Hydrology, vol. 240, pp. 23-44.

Weld, J.L. \& Beegle, D.B. (2001), A summary of phosphorus indices. SERA17 Meeting, July 18-21, State College, PA, USA, 40 pp 


\subsection{The P Index: US Experience ${ }^{3}$}

\section{Douglas Beegle}

Department of Crop and Soil Sciences, Penn State University, University Park, PA 16802, USA, dbb@psu.edu

Traditionally nutrient management has been concerned with optimizing the economic return from nutrients used for crop production. Today, the agronomic and economic requirements of nutrient management remain central but in addition the process must consider the potential impact of these nutrients on environmental quality. The U.S. Environmental Protection Agency ranks eutrophication as the most widespread water quality impairment in the U.S. (U.S. Environmental Protection Agency, 1996), and agriculture, particularly agriculture involving intensive livestock production, has been identified as a primary source of $\mathrm{P}$ in surface waters (U.S. Geological Survey, 1999).

The problems with nutrient pollution are not generally the result of mismanagement by farmers but are a result of how our agricultural systems have evolved with no direct costs associated with environmental quality. Intensive livestock farming enterprises, which concentrate large numbers of animals on relatively small land areas, have emerged as a result of improvements in animal housing and the success of crop production on cash-crop farms in specialized geographic regions. Most, if not all, of the feed necessary can be economically transported to the farm where the animals are housed. The focus of the management activity is on animal production. Nutrients in this flow usually do not cycle back to the cash-crop farm. The nutrient excess on the intensive livestock farm has an associated increased potential for losses to the environment (Beegle et al., 2000).

In response to mounting environmental concerns from nutrients, many states have developed guidelines and regulations for land application of manure. At the federal level, the U.S. Department of Agriculture (USDA) and U.S. Environmental Protection Agency (USEPA) created a joint unified strategy for nutrient management on Animal Feeding Operations (AFOs), with a national deadline for implementation of 2008 (U.S. Department of Agriculture and U.S. Environmental Protection Agency, 1999). This strategy went beyond the traditional primary emphasis on $\mathrm{N}$ and stated that: "At a minimum, nutrient management should prevent the application of nutrients ( $\mathrm{N}$ and $\mathrm{P}$ ) at rates that will exceed the capacity of the soil and the planned crops to assimilate nutrients and prevent pollution.” This strategy is currently being implemented through regulations

\footnotetext{
${ }^{3}$ Much of this paper is derived from collaborative research and extension work at Penn State University and the USDA-ARS Pasture Systems and Watershed Management Research Unit at University Park, PA. A more in-depth paper on this subject has recently been published by these collaborators (Sharpley et al., 2003).
} 
on large confined animal feeding operations (CAFOs) and requirements for federal financial and technical assistance programs for farmers. Many states are also implementing nutrient management programs and regulations based on this strategy.

Under this strategy, three approaches are identified for managing $\mathrm{P}$ to protect water quality. These approaches are agronomic soil test P (STP) recommendations, environmental STP thresholds, or a P Index to rank fields according to their vulnerability to potential P loss. In the agronomic soil test $\mathrm{P}$ option, manure rates would be based on the recommendations for optimum production of the crop. However, agronomic STP interpretations are not directly related to environmental risk of $\mathrm{P}$ loss (Kleinman et al., 2000). In the environmental STP threshold option, a soil P level is established above which there is a significant threat of $\mathrm{P}$ loss to the environment. While this is based on a soil test, it would be interpreted based on a research relating the soil level to actual potential for $\mathrm{P}$ loss to the environment. It has been clearly shown that STP is strongly related to dissolved $\mathrm{P}$ in runoff from soils that have not recently received additions of manure and/or mineral fertilizer. However the relationship is very poor when there are manure applications to the soils (Sharpley et al., 2001).

The P Index approach is based on the fact that most P loss to water comes from only a small part of the landscape during a few storm events. These areas of the landscape that have high sources of $\mathrm{P}$ either from the soil or recent $\mathrm{P}$ applications and a mechanism to transport that $\mathrm{P}$ to water are referred to as critical source areas (Gburek and Sharpley, 1998; Pionke et al., 2000). The P Index is used to identify and guide management of critical source areas in a watershed as they are most vulnerable to $\mathrm{P}$ loss (Gburek et al., 2000). The P Index was developed to determine a relative assessment of site vulnerability to $\mathrm{P}$ loss.

In the US, 47 out of 50 states have adopted the P Index approach to manage P for environmental quality protection (Figure 1, Sharpley et al., 2003). Sharpley et al. (2003) have summarized the process leading to the development and adoption of the P Index in the US and have provided a detailed summary of the individual P Indices currently in use across the country. There are several key source and transport factors that are common to most P Indices in the US. The common source factors are: STP, applied fertilizer P, and applied organic sources of P. In many of the Indices, the applied fertilizer and organic P amounts are modified based on method and timing of application. The common transport factors include: soil erosion, runoff, leaching, and distance to water. In addition, some Indices include other factors such as: flooding frequency, presence of artificial drainage, presence of BMPs, receiving water priority, STP modifiers for $\mathrm{P}$ saturation soil $\mathrm{pH}$, soil texture, reactive aluminum, and availability factors for applied $\mathrm{P}$ sources. The Pennsylvania $\mathrm{P}$ Index is shown in Figure 2 as an example of a typical P Index used in the US. 


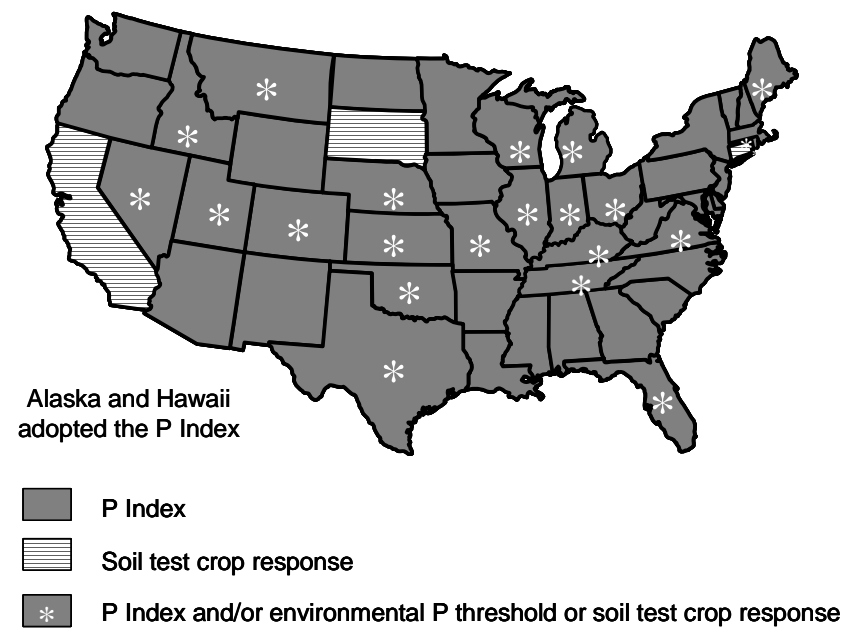

Figure 1. Phosphorus management strategies adopted in the US. (Sharpley et al., 2003)

The original P Index developed by Lemunyon and Gilbert (1993) was additive as the final P Index value was calculated by adding the source and transport factors. While many P Indices have followed this original approach, almost half of the Indices follow a multiplicative approach multiplying the source factor by the transport factor. This multiplicative approach better represents site vulnerability (Gburek et al., 2000) because with the additive approach an areas with a high source regardless of transport potential would receive a high P Index rating. In the multiplicative approach, a high source with a low transport would not necessarily have a high P Index value. A high P Index would be achieved when both the source and transport were high.

In most $\mathrm{P}$ Indices, the final $\mathrm{P}$ Index value is determined from composite source and transport factors that combine all sources and apply a composite Index of the transport factors to those sources. In some states (Virginia, Iowa, New York) the P Index has been modified to account for specific soluble and particulate P sources and transport mechanisms separately. These are then combined to arrive at a final P Index value. While this is conceptually more appealing, it does result in a significantly more complex P Index. 


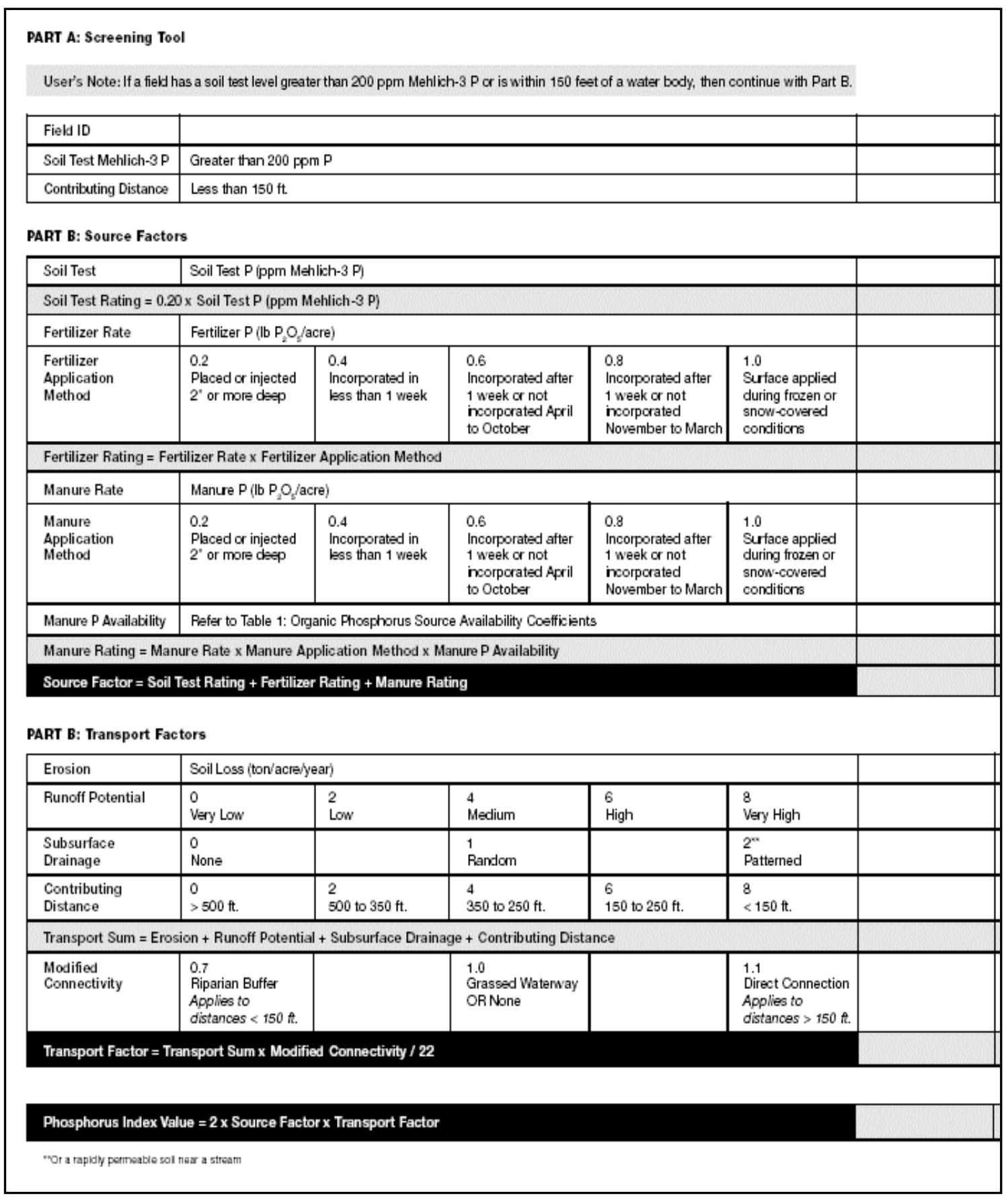

Figure 2. Example P Index. Pennsylvania P Index: Version 1 (Weld et al., 2003)

Several P Indices go beyond simply identifying relative site vulnerability to $\mathrm{P}$ loss and attempt to make an estimate of actual P loading from a site. This approach has resulted in considerable discussion about the P Index as a P loss model. Many models have been developed (Sharpley et al., 2002) to predict $P$ loss. These models are invaluable for understanding $P$ loss processes and developing assessment tools and management ap- 
proaches. However, for the P Index to be useful to use by planners in assessing vulnerability to $\mathrm{P}$ loss it must be based on readily available data and be relatively easy to calculate. Most P loss models are too complex for use as a practical field indexing tool. It is important to keep in mind this practical difference between a P loss model and a P Index.

A general interpretation scheme for the $\mathrm{P}$ Index values was proposed as part of the USDA-USEPA unified national strategy for nutrient management (U.S. Department of Agriculture and U.S. Environmental Protection Agency, 1999). These interpretation categories and general management guidance have been used in most P Indices (Table 1); however, there is no guidance in the unified strategy for establishing the actual " $P$ Index values" to delineate each category. Unfortunately, there is currently little direct calibration of the P Index. Due to the lack of actual calibration data, several other approaches have been used to establish the P Index categories. The most common approach uses data on the individual factors in the P Index to collectively estimate site vulnerability to P loss. Typically low, medium, high, and very high values for the individual components are entered and the result assigned to the appropriate P Index rating category. As an example, the P Index values used to for the categories in the Pennsylvania P Index are shown in Table 1.

Table 1. P Index interpretation categories from the Pennsylvania P Index (Weld et al., 2003). The "Ratings" and "Management Guidance" are taken from the Unified Nation Strategy for Nutrient Management (U.S. Department of Agriculture and U.S. Environmental Protection Agency, 1999)

\begin{tabular}{|c|c|c|c|}
\hline $\begin{array}{l}P \text { Index } \\
\text { value }\end{array}$ & Rating & General interpretation & $\begin{array}{l}\text { Management } \\
\text { guidance }\end{array}$ \\
\hline$<59$ & Low & $\begin{array}{l}\text { If current farming practices are maintained, there } \\
\text { is a low risk of adverse impacts on surface waters }\end{array}$ & $\begin{array}{l}\text { N-based } \\
\text { applications }\end{array}$ \\
\hline $60-79$ & Medium & $\begin{array}{l}\text { Chance for adverse impacts on surface waters } \\
\text { exists, and some remediation should be taken to } \\
\text { minimize P loss }\end{array}$ & $\begin{array}{l}\mathrm{N} \text {-based } \\
\text { applications }\end{array}$ \\
\hline $80-99$ & High & $\begin{array}{l}\text { Adverse impact on surface waters. Conservation } \\
\text { measures and P management plan are needed to } \\
\text { minimize P loss. }\end{array}$ & $\begin{array}{l}P \text { application } \\
\text { limited to crop } \\
\text { removal of } P\end{array}$ \\
\hline $\begin{array}{l}100 \text { or } \\
\text { greater }\end{array}$ & Very high & $\begin{array}{l}\text { Adverse impact on surface waters. All necessary } \\
\text { conservation measures and P management plan } \\
\text { must be implemented to minimize P loss. }\end{array}$ & No P applied \\
\hline
\end{tabular}

Another approach that has been used is to simply look at the population of P Index values for the area where the Index will be used and select a certain percentage of the sites that will be designated as high. The rationale, for example, might be to establish that you want to designate the worst $10 \%$ of the population as very high risk. A critical level would be selected to achieve this percentage in the very high category. While this approach will target the worst cases on a relative basis, there is no direct relationship between the $\mathrm{P}$ Index categories and actual risk of $\mathrm{P}$ loss. Consequently, there is a critical need for field calibrations of the P Index to establish criteria for these interpretation categories. 
Finally, while significant fundamental research on P loss and assessment of $\mathrm{P}$ loss potential continues, there has been a new emphasis in the US related to P Index implementation. This has ranged from developing policy to implement the $\mathrm{P}$ Index to nutrient management programs to training and technical assistance for integrating the P Index into the nutrient management planning process. For example, a project by Weld et al. (2002) examined the agronomic and economic impact of P Index implementation on eleven typical Pennsylvania farms and also assessed the nutrient management plan development process using a P Index through public and private sector nutrient management planners. In this assessment, the P Index results showed that $23 \%$ of the fields had high or very high $P$ Index values and would have required management changes. The economic impact was variable with a greater impact on poultry and swine farms than on dairy farms. Manure transport distance had the most significant economic impact. The further the manure was transported to find land suitable for application the higher the cost to farm producing the manure. This cost is exacerbated on swine and poultry farms because they tend to cluster in areas near to feed mills making it more difficult to find manure importers nearby. Overall, the P Index approach had less economic impact than the soil test approaches.

Feedback from farmers and planners indicated that the P Index approach made the most sense and seemed to be more practical than STP management options.. However, planners identified concerns regarding increased time and cost for P Index nutrient management plan development. Specific concerns included time to collect the necessary field by field source and transport data and estimating soil erosion with the revised universal soil loss equation (RUSLE). These time and cost issues are being examined nationally and as a result nutrient management planning software with an integrated Index has been developed and existing databases such as digital elevation models and soils databases have been used to minimize the need for field measurements.

Another common approach to address workload concerns is the use of a screening tool to perform a preliminary site screening identifying sites not likely to need a rigorous P Index evaluation. An effective screening tool must have a rational basis and provide a simple but accurate gross categorization of sites. For example, the Pennsylvania P Index screening tool (Figure 2) utilizes the STP level and the distance to water. If a site has a Mehlich 3 STP level greater than 200 ppm or the edge of the field is within $150 \mathrm{ft}$ of water, then the complete P Index evaluation is required. In the farm evaluations by Weld et al. (2002), approximately $20 \%$ of the fields fell into the high or very high categories. The screening tool selected approximately $30 \%$ of all fields for complete P Index assessment, and it successfully selected over $95 \%$ of the fields with a high or very high P Index rating. 
The P Index approach has been widely adopted in the US to develop nutrient management plans that effectively address concerns about P loss to water. At the same time this approach has been shown to be practical to implement both in terms of the planning process and more importantly for sustaining economical animal agriculture. Research continues to improve the P Index, focusing both on the fundamental processes involved in $\mathrm{P}$ loss and in the more applied area of management approaches to implement $\mathrm{P}$ based nutrient management plans.

\section{References}

Beegle, D.B., Carton, O.T. \& Bailey, J.S. (2000), Nutrient Management Planning: Justification, Theory, Practice. J. Environ. Qual., vol. 29, pp. 72-79.

Gburek, W.J., Sharpley, A.N., Heathwaite, L. \& Folmar, G.J. (2000), Phosphorus management at the watershed scale: A modification of the phosphorus index. J. Environ. Qual., vol. 29, pp. 130144.

Gburek, W.J. \& Sharpley, A.N. (1998), Hydrologic controls on phosphorus loss from upland agricultural watersheds. J. Environ. Qual., vol. 27, pp. 267-277.

Kleinman, P.J.A., Bryant, R.B., Reid, W.S., Sharpley, A.N. \& Pimental, D. (2000), Using soil phosphorus behavior to identify environmental thresholds. Soil Sci., vol. 165, pp. 943-950.

Lemunyon, J.L. \& Gilbert, R.G. (1993), The concept and need for a phosphorus assessment tool. Journal of Production Agriculture, vol. 6, pp. 483-496.

Pionke, H.B., Gburek, W.J. \& Sharpley, A.N. (2000), Critical source area controls on water quality in an agricultural watershed located in the Chesapeake Basin. Ecolog. Eng., vol. 14, pp. 325335.

Sharpley, A.N., Weld, J.L., Beegle, D.B., Kleinman, P.J.A., Gburek, W.J., Moore, P.A. Jr. \& Mullins, G. (2003), Development of phosphorus indices for nutrient management planning strategies in the United States. J. Soil Water Conserv., vol. 58(3), pp. 137-152.

Sharpley, A.N., Kleinman, P.J.A., McDowell, R.W., Gitau, M. \& Bryant,
R.B. (2002), Modeling phosphorus transport in agricultural watersheds: Processes and possibilities. J. Soil Water Conserv., vol. 56, pp. 425-439.

Sharpley, A.N., McDowell, R.W., Weld, J.L. \& Kleinman, P.J.A. (2001), Assessing site vulnerability to phosphorus loss in an agricultural watershed. J. Environ. Qual., vol. 30, pp. 2026-2036.

U.S. Department of Agriculture and U.S. Environmental Protection Agency (1999), Unified national strategy for Animal Feeding Operations. March 9, 1999. U.S. Government. Printing Office, Washington, D.C.

U.S. Environmental Protection Agency (1996), Environmental indicators of water quality in the United States. EPA 841-R-96-002. U.S. EPA, Office of Water (4503F). U.S. Government. Printing Office, Washington, D.C. U.S. Geological Survey (1999), The quality of our nation's waters: Nutrients and pesticides. U.S. Geological Survey Circular 1225, USGS Information Services, Denver, CO. 82 pp.

Weld, J.L., Beegle, D.B., Gburek, W.J., Kleinman, P.J.A. \& Sharpley, A.N. (2003), The Pennsylvania Phosphorus Index: Version 1. Publications Distribution Center, Pennsylvania State University, University Park, PA.

Weld, J.L., Parsons, R.L., Beegle, D.B., Sharpley, A.N., Gburek, W.J. \& Clouser, W.R. (2002), Evaluation of phosphorus management strategies in Pennsylvania. J. Soil Water Conserv., vol. 57, pp. 448-454. 


\title{
3.6 Development of a Phosphorus index for Norway - Input data sources for the Skuterud catchment
}

\author{
Marianne Bechmann \\ Jordforsk, Norwegian Centre for Soil and Environmental Research
}

\section{Introduction}

Eutrophication of most freshwaters in Norway is limited by the concentration of phosphorus (P) (Berge, 1987). Focus on point sources during the 1980s has made non-point sources a major source of $\mathrm{P}$ from agricultural catchments. The non-point losses of $\mathrm{P}$ from agricultural land in Norway have been targeted by allocating subsidies to reduced tillage on high-risk areas of erosion and by means of regulations of livestock density and manure management. These measures were implemented to reduce losses of $\mathrm{P}$ and soil particles from agricultural land (Table 1). However, studies at catchment scale have not shown the desired reductions in $\mathrm{P}$ losses from agricultural areas. Furthermore, implementation of the Water Framework Directive has focused interest on water quality of surface waters. Hence, there is a need to improve the efforts.

Table 1. Farm policy measures for mitigating $P$ losses from agriculture in Norway (Norwegian Ministry of Agriculture, 2003)

\begin{tabular}{ll}
\hline Source measures & Transport measures \\
\hline Livestock density; $2.5 \mathrm{AMU} \mathrm{ha}^{-1}$ & Reduced autumn tillage \\
Capacity for manure storage for 8 months & Contour ploughing \\
No manure application November $1^{\text {st }}-$ February $15^{\text {th }}$ & Vegetated buffer strips \\
Incorporation of manure within 18 hours on arable land & Hydrological measures (e.g. intake of surface water) \\
$\mathrm{P}$ application plan based on soil P test & Grassed waterways \\
\hline
\end{tabular}

A risk assessment tool to define critical source areas of $\mathrm{P}$ losses may be a useful tool for strategies to reduce P losses in Norway. The P index, which was developed in the USA, is one such tool. The P index identifies areas where sources of $\mathrm{P}$ and transport of $\mathrm{P}$ coincide. In the $\mathrm{P}$ index all factors, which are important for $\mathrm{P}$ losses (both source and transport) for a certain region are included. In general source factors include soil $\mathrm{P}$ content and $\mathrm{P}$ application (including rate, method and time of application and availability of $\mathrm{P}$ in manure) and the transport factors include soil erosion, surface runoff, subsurface runoff, buffer zones and distance to surface water. The $\mathrm{P}$ index is usually applied on a field-by-field basis, as this is a manageable unit for farmers. Since the P index is a simple model, based on expert knowledge and empirical research, it cannot be transferred from one region to another without adjustment to local conditions. 


\section{A Norwegian P index}

Factors in the Pennsylvanian P index (Beegle, this issue) were justified for use in Norway (Bechmann et al., 2003). In addition to factors in the Pennsylvanian $\mathrm{P}$ index, the suggested $\mathrm{P}$ index for Norway has included factors for P surplus, $\mathrm{P}$ release by freezing of green plant material and regional differences in precipitation (Table 2). However, there is a need for further development of the $\mathrm{P}$ index to reflect Norwegian conditions, e.g. winter, snowmelt and the intensive tile drainage. The subsurface drainage factor in the Pennsylvanian P index has been replaced by a factor for risk of leaching according to Andersen and Kronvang (this issue). They suggest that a factor for leaching should be included to account for the different abilities of soils to leach P. The risk of leaching being sand $<$ clay < organic soil. P losses through leaching from tile-drained soils are shown to contribute significantly to P losses in Norway. Experiments have shown high $\mathrm{P}$ concentrations in drainage water, both dissolved as phosphates and attached to soil particles as vertical erosion through the macropore systems (Oskarsen et al., 1998; Lundekvam, 1998). Surface runoff of dissolved $\mathrm{P}$ is an important $\mathrm{P}$ loss process in areas with grasslands and surface application of $\mathrm{P}$, while in areas with cereals, like in the Skuterud catchment, surface runoff is usually associated with erosion rather than transport of dissolved P. Hence, surface runoff has no separate representation but is rather represented by the erosion factor.

In the presented $\mathrm{P}$ index (Table 2) the connectivity factors (contributing distance and modified connectivity) reflect the Pennsylvanian P index approach. These two factors need further development to represent the differences between surface erosion and leaching. Tile drainage causes fields to be directly connected to the recipient through the drainage water. The factor for modified connectivity is hence only true for the surface erosion part of the $\mathrm{P}$ transport. The $\mathrm{P}$ index was developed for conditions where surface losses of $\mathrm{P}$ were dominating. For tile-drained soils it may be more appropriate to divide the transport part of the $\mathrm{P}$ losses into at least two separate parts: one for surface losses and one for P losses through leaching.

Another special condition in Norway are the hydraulic constructions for intake of surface water to reduce concentrated flow. These constructions cause a reduction in the "hydrologic distance" from field to recipient. Further development of the P index in relation to hydrologic conditions is important for a proper ranking of fields according to their risk of $\mathrm{P}$ loss. 
Table 2. The Norwegian $P$ Index used for the Skuterud catchment

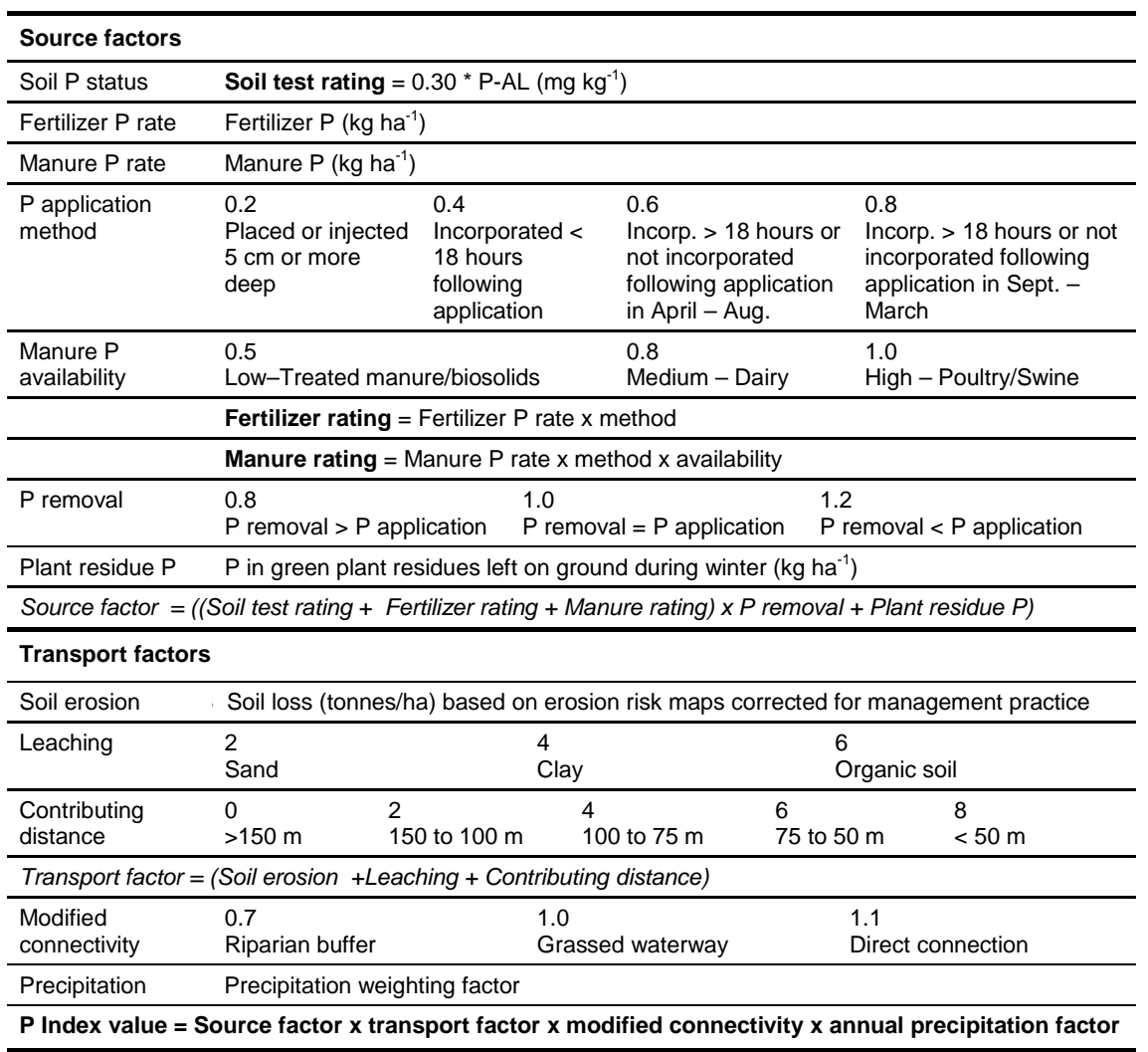

\section{Input data sources}

Data availability limits the sophistication of the P index. One of the basic assumptions of the $\mathrm{P}$ index is that it should be applicable for all farmed fields. The Norwegian approach to the P index is based on input data, which are available at a national scale or which are available for farmers in relation to their nutrient management planning. The availability of input data for a $\mathrm{P}$ index is discussed below.

Data on soil $\mathrm{P}$ status and application of $\mathrm{P}$ in fertiliser and manure are available from the farmer's nutrient management plan (Figure 1 and 2). From the nutrient management plan farmers may also derive data for $\mathrm{P}$ removed in yield and $\mathrm{P}$ in green plant residues left on the ground during winter. Standard values are used when no analyses of $\mathrm{P}$ content have been carried out. Bechmann et al. (in prep.) have shown that the release of $\mathrm{P}$ from plants increases with increasing number of freeze-thaw cycles and approach the total P content in the plants (Figure 3). 


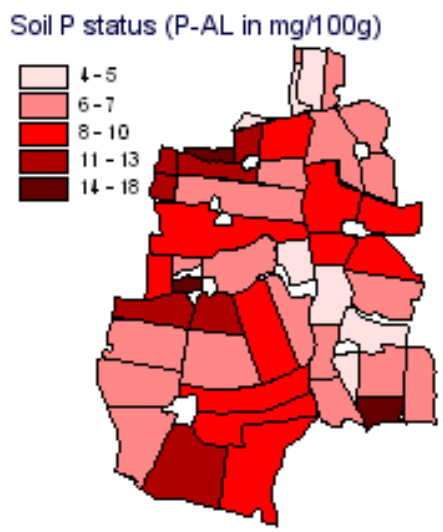

Figure 1. Soil P status on fields in the Skuterud catchment

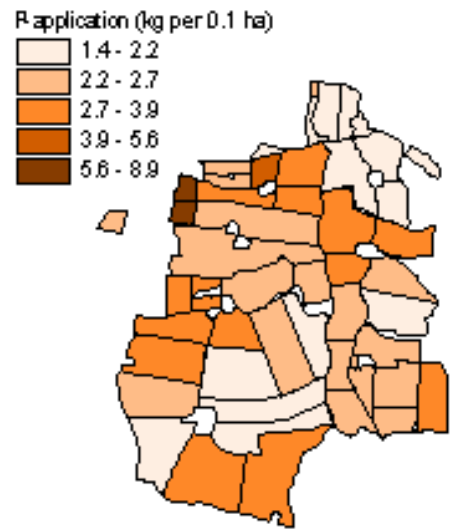

Figure 2. Annual $P$ application rate (fertiliser and manure)in $\mathrm{kg} / 0.1 \mathrm{ha}$ on fields in the Skuterud catchment

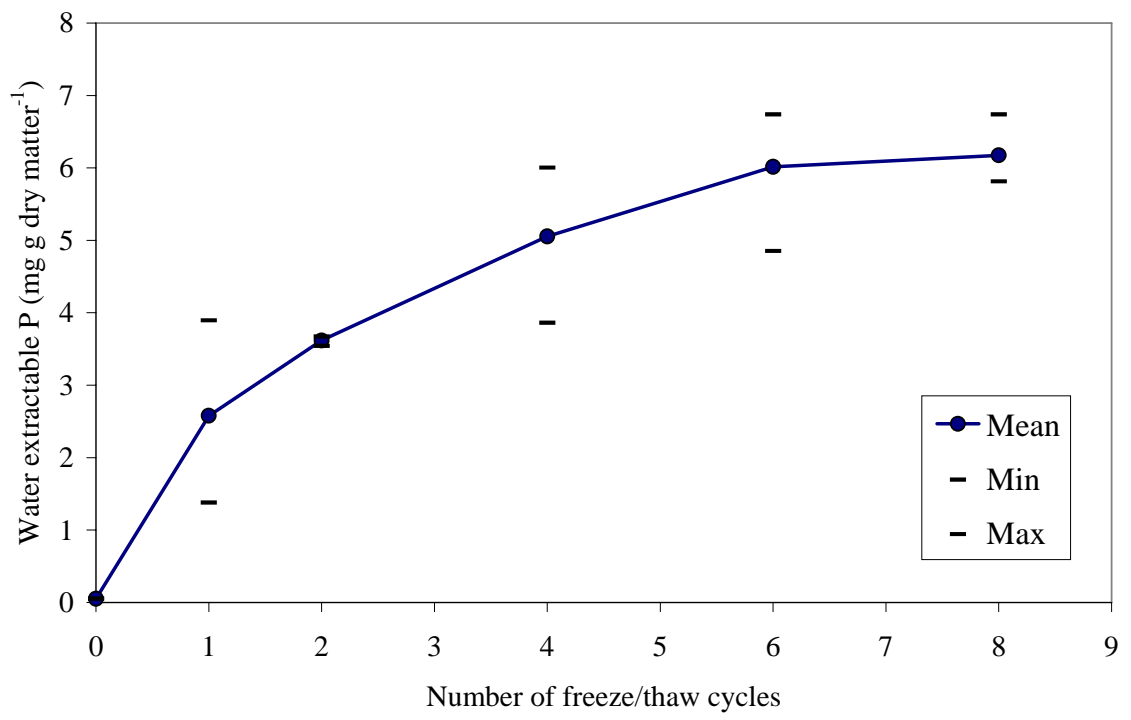

Figure 3. The release of water extractable $P$ from plants in relation to number of freeze-thaw cycles (Bechmann et al., in prep.) 
In the $\mathrm{P}$ index the erosion factor is based on national erosion risk maps (The Norwegian Institute of Land Inventory - NIJOS). These maps are easily available for most agricultural land in Norway and base the risk assessment on texture and slope data from in-field surveys. They are presented for a standard of autumn ploughing. However, they may not take into account all important erosion processes, e.g. slope length and differences in erosion risk caused by differences in snowmelt. Improved risk assessment for $\mathrm{P}$ loss is very much dependent on improvements in erosion risk assessments.

Another discrepancy between erosion risk maps and erosion risk for a field is the scale issue. Figure 4 shows that erosion risk for the Skuterud catchment varies both among and within fields. A certain erosion risk at field level may cover a variety of erosion risk levels within the field. In some cases there will probably be a need to manage fields according to the in-field variability.

The connectivity may be represented by a straight line measurement or it may be related to the actual distance that water flows. In this case no in-field evaluation of waterway distance was carried out.

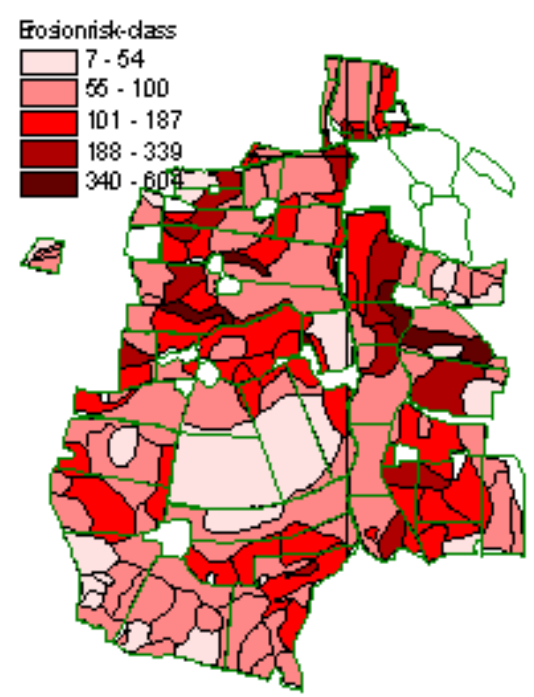

Figure 4. Spatial distribution of erosion risk for the Skuterud catchment in Norway

\section{The Skuterud catchment}

The Skuterud catchment is an agriculturally dominated area with cereals as the main production (93\% of the area). Data for the agricultural area in the year 2001 were used to calculate the $\mathrm{P}$ index values for each field (Figure 5). Size of fields varies from 0.3 to 17.1 ha. Two farms produce meat (pigs and cattle) resulting in manure application of up to $48 \mathrm{~kg} \mathrm{P} / \mathrm{ha}$. Fertiliser application varies from 12 to $35 \mathrm{~kg}$ P/ha and soil P status (P$\mathrm{AL}$ ) at field scale varies from 4 to 18 . Catch crops, grassland and winter wheat cover areas of 4, 14 and 63 ha, respectively. All fields are tile- 
drained at a spacing of about 8 meters and $\mathrm{P}$ losses occur both by erosion on the soil surface and through the tiles. The soil type consists of loam (81 \%) and sand (19\%). The major P form lost from this catchment is particulate $\mathrm{P}$ (Table 3 ). No vegetated buffers or grass-covered waterways were recorded. The contributing distance from edge-of-field is up to 675 meters.

Table 3. Losses of suspended sediments (SS), total phosphorus (TP), dissolved reactive phosphorus (DRP) and discharge from the Skuterud catchment 1993-2002 calculated for the agricultural area

\begin{tabular}{lcccc}
\hline & SS (tonnes/ha) & TP (kg/ha) & DRP (kg/ha) & Discharge (mm) \\
\hline 1994 & 2.1 & 2.7 & 0.5 & 463 \\
1995 & 1.0 & 1.3 & 0.2 & 502 \\
1996 & 0.4 & 0.9 & 0.2 & 278 \\
1997 & 0.8 & 1.3 & 0.2 & 293 \\
1998 & 1.1 & 2.1 & 0.4 & 487 \\
1999 & 3.3 & 4.3 & 0.6 & 702 \\
2000 & 3.1 & 5.9 & 0.7 & 919 \\
2001 & 1.5 & 2.4 & 0.4 & 608 \\
2002 & 1.3 & 2.6 & 0.4 & 526 \\
\hline
\end{tabular}

Only $2 \%$ of the Skuterud catchment fell in the classes of high and very high risk of $\mathrm{P}$ losses according to this $\mathrm{P}$ index evaluation (Figure 5). The main part of the catchment is divided into three equal size classes, medium, low and very low $\mathrm{P}$ index.

According to this calculation high risk areas were a result of mainly soil $\mathrm{P}$ status and manure application. Evaluation of the sensitivity of the $\mathrm{P}$ index is presented in Figure 6 for the erosion risk factor and the soil P status.

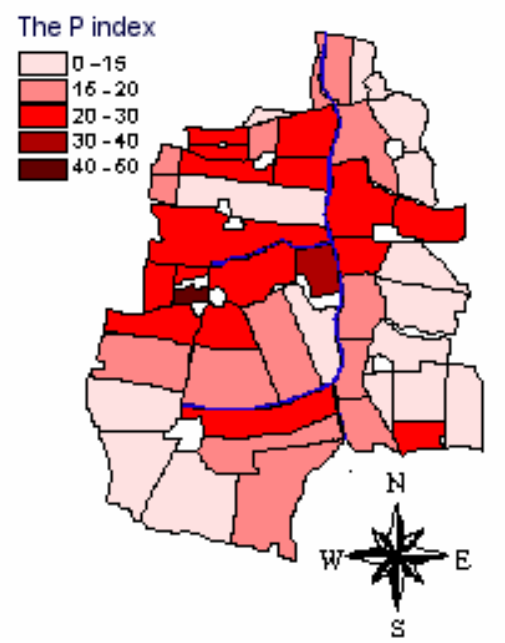

Figure 5. $P$ index values calculated for fields in the Skuterud catchment 

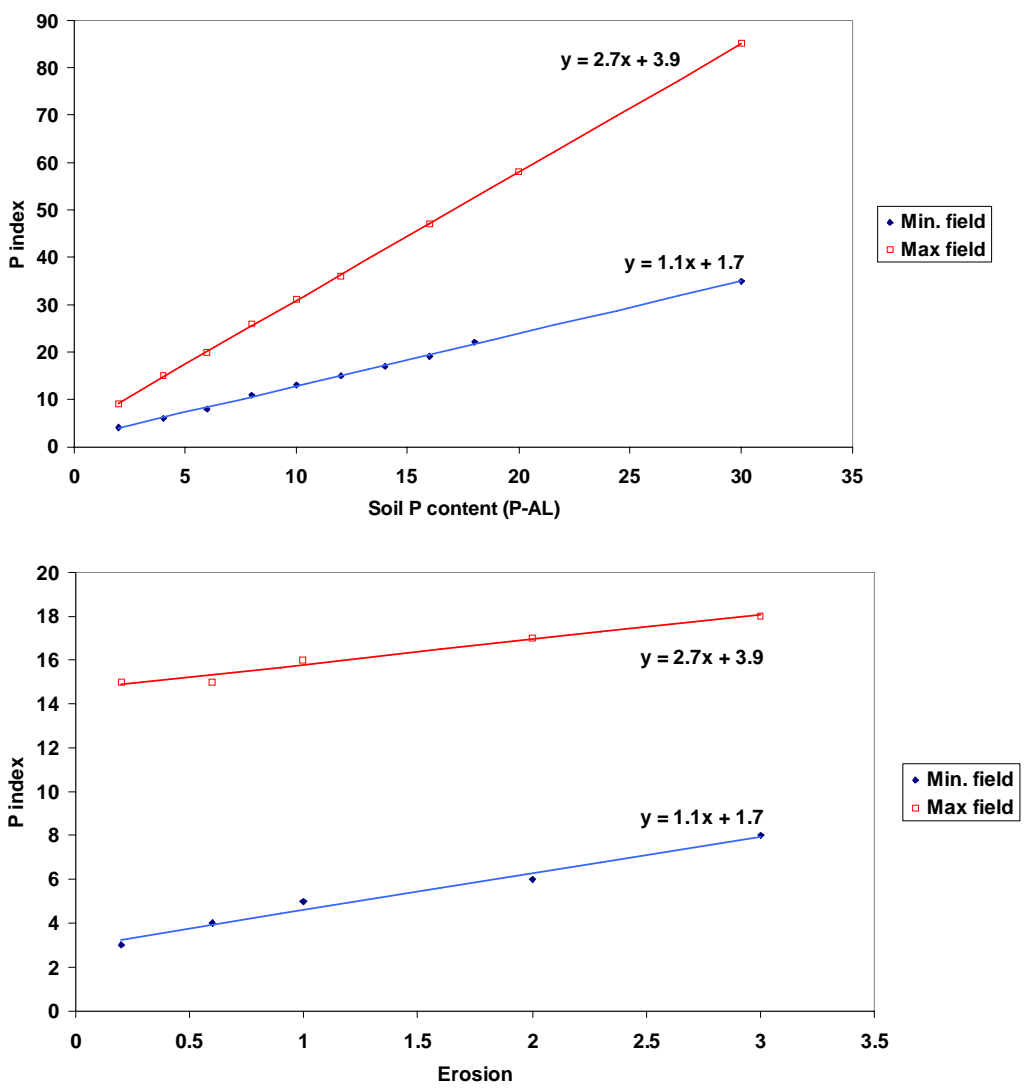

Figure 6. Sensitivity of the $P$ index to changes in soil $P$ status (upper fig.) and erosion risk (lower fig.) in the Skuterud catchment

Erosion is an important $\mathrm{P}$ loss process in the Skuterud catchment, since $80 \%$ of TP in runoff is particle-bound. The sensitivity of the P index approach, with the weighting from the Pennsylvanian $\mathrm{P}$ index, does not reflect the importance of different processes in Norway. Further development based on Norwegian research and empirical models should be carried out to give factors in the index proper weights for Norwegian conditions.

\section{Concluding remarks}

As the environmental aspects gain increased focus in nutrient management planning, the $\mathrm{P}$ index may be valuable as a decision support tool at field scale. Input data for the $\mathrm{P}$ index are available from statistical sources and from the farmers themselves. The $\mathrm{P}$ index is, at present, not a fully developed tool for Norwegian conditions, since the factors are not weighted according to their actual influence on $\mathrm{P}$ losses. For example the effect of erosion risk in the P index is too low. Calibration of the P index is needed to use this tool to select high risk areas. 


\section{References}

Bechmann, M.E., Krogstad, T. \& Sharpley, A.N. (2003), A Phosphorus Index for Norway: Justification of factors. Proceedings of the International Water Association, Diffuse Pollution Conference. Dublin, 2003.

Bechmann, M.E., Kleinman, P. \& Sharpley, A.N. (2005), Surface and subsurface runoff of phosphorus from frozen soil with catchcrop or manure compared to bare soil. J. of Environ. Qual. (in press).

Berge, B. (1987), Fosforbelastning og respons i grunne og middels grunne innsjøer. Norwegian Institute for Water Research Report No. O-85110, 45 pp. (in Norwegian).

Lundekvam, H. (1998), P-losses from three soil types at different cultivation systems. K. Skogs- og Lantbr. Akad. Tidskr., vol. 137(7), pp. 177-185.

Oskarsen, H., Haraldsen, T.K., Aastveit, A.H. \& Myhr, K. (1998), The Kvithamar field lysimeter II. Pipe drainage, surface runoff and nutrient leaching. Nor. J. Agric. Sci., vol. 10, pp. 211-228. 


\subsection{Development of Swedish P index - how far can we reach with the existing knowledge?}

\section{Faruk Djodjic}

Swedish University of Agricultural Sciences, Department of Soil Sciences, Division of Water Quality Management, P.O. Box 7072, S-75007 Uppsala, Sweden

\section{Introduction}

Phosphorus index (PI) as a risk assessment tool has been used in Sweden as one component of a decision support system for phosphorus (P) management at watershed scale (Djodjic et al., 2002). The Maryland PI was used in this study within a GIS environment as a tool to identify critical source areas within a watershed, whereas the expert systems were used to make a diagnosis of the site-specific probable causes of $\mathrm{P}$ losses and the recommendation of suitable management options for $\mathrm{P}$ loss reduction. Finally, a hydrologic non-point source pollution model was used to assess the effects of the recommended Better Management Practices (BMPs).

This approach, where our mitigation efforts are focused on the highrisk areas, is based on the assumption that the abatement strategies will be most effective if applied on the parts of the watershed that are main contributors to the $\mathrm{P}$ losses. However, this approach also emphasizes the importance of a reliable and accurate tool for identification of the critical source areas. Therefore, PI as a risk assessment tool has a crucial role and must be adjusted for the specific conditions regarding soils, climate, crop management and data availability.

The concept of PI has been developed in the USA and is based on a P source-P transport mechanism approach, i.e., the areas having the greatest risk of $\mathrm{P}$ losses are the areas where $\mathrm{P}$ sources (soil $\mathrm{P}$, fertilizer/manure $\mathrm{P}$ ) overlap with areas with effective transport mechanisms, such as erosion, surface runoff and subsurface drainage. It should be noted that the main focus has been on surface runoff and erosion as the main transport pathways for P movement in the eastern USA, although some attempts to describe $\mathrm{P}$ losses through subsurface drainage have been made. Phosphorus index has evolved from an additive (Lemunyon and Gilbert, 1993) to a multiplicative approach (Gburek et al., 2000), to emphasize the importance of simultaneous presence of $\mathrm{P}$ source and $\mathrm{P}$ transport mechanism.

One of the main advantages of PI in comparison to more complex, process-oriented hydrologic models is its simplicity in terms of the requested input data and its user-friendliness. Therefore, all efforts for improvements and sophistication of PI must be balanced with the availability of the requested data as well as with its educational value. This aspect of PI is often underestimated. The calculation of PI in collaboration with farmers should be a useful discussion base for the actual P management pratice. 
Phosphorus losses in Sweden are strongly influenced by specific soil, climate and management conditions. Snow cover, snow melting and soil freezing and thawing phenomena influence water and $\mathrm{P}$ transport. Precipitation intensity is usually low and episodes of water erosion generally occur during snowmelt and when frozen soil thaws (Alström and Bergman, 1990). Erosion intensity is rarely of a magnitude that causes land degradation problems, but it may increase losses of nutrients, especially P.

The majority of the Swedish arable land is situated in the flat areas of southern and central Sweden. Approximately 1.2 out of total 2.7 million hectares are tile drained (SCB, 1997), including the majority of structured clay soils. This, in combination with the preferential flow pathways occurring in such soils, results in an increased risk of $\mathrm{P}$ losses through leaching (Djodjic, 2001). In addition, high leaching losses have been documented from heavily fertilized sandy soils with low P sorption capacity (Ulén et al., 2001).

The above-mentioned reasons created a need for the development of a Swedish PI, adjusted for typical climate and soil conditions, and relevant for the patterns of $\mathrm{P}$ losses and available data. This is an ongoing project, which has gained financial support from the project Food 21 and the Swedish Farmers' Foundation for Agricultural Research, which is gratefully acknowledged.

\section{Approach}

The development of the Swedish PI is based on the available and applicable knowledge about $\mathrm{P}$ transport from arable fields to adjacent water bodies. The main objective of this synthesis work is the development of a user-friendly tool for P risk assessment at field level, using a somewhat adjusted PI concept and existing experience, combined with the available data describing the major factors that influence P loss risk.

\section{Concept}

The importance of P losses through subsurface drainage in Sweden emphasizes the necessity for a proper description of that transport pathway in PI. Additionally, PI calculations should account for P losses through both preferential and matrix flow and take into consideration the importance of different factors (for example P sorption capacity and/or degree of $\mathrm{P}$ saturation) for each transport mechanism. The multiplicative version of PI adds the ranking values of the different factors within the P source group and $\mathrm{P}$ transport group and then multiplies the sums to obtain the total $\mathrm{P}$ index value. This also implies that each $\mathrm{P}$ source (soil $\mathrm{P}$, fertilizer/manure $\mathrm{P}$ ) is equally affected by each transport factor (surface runoff, matrix flow, preferential flow), and each P form ((reactive (RP) and unreactive P (UP)) is equally treated in different transport pathways. For 
example, a high soil $\mathrm{P}$ test in the topsoil may result in a high total PI value regardless of the main transport pathway. However, this high potential for P losses will be fulfilled only if the buffering capacity of the subsoil is either low or bypassed through surface runoff or preferential flow. Hence, the importance of some factors may be reduced or emphasized by other factors. Introduction of conditional rules in the PI calculations, where factors are switched on and off depending on their interplay with other factors, may therefore better describe risk of P losses. Table 1 shows the structure of Swedish PI.

Table 1. Structure of Swedish PI.

\begin{tabular}{llll}
\hline & \multicolumn{2}{l}{ Slope, Permeability(k) } \\
\cline { 2 - 4 } & Surface Runoff & $\begin{array}{l}\text { Subsurface Drainage } \\
\mathbf{k} \text {, soil structure }\end{array}$ \\
\cline { 3 - 4 } & & Preferential flow & Matrix flow \\
\hline DPS f(P-AL/PSI) & RP & RP & RP \\
P fert. f(P rate, method, time) & RP, UP & RP, UP & RP, UP \\
RUSLE (A=R* $\left.K^{\star} L S^{*} C^{*} P\right)$ & UP & UP & $*$ \\
PER (Texture, $P-A L)$ & UP & UP & $*$ \\
BZ & UP & $*$ & $*$ \\
FCon f(Drainage, Runoff wells) & RP, UP & RP, UP & RP, UP \\
\hline
\end{tabular}

DPS, degree of $\mathrm{P}$ saturation; $\mathrm{PSI}$, single-point $\mathrm{P}$ sorption index; PER, $\mathrm{P}$ enrichment ratio; $\mathrm{BZ}$, buffer zone; Fcon, field connectivity; RP, reactive P; UP, unreactive P;

Besides introduction of the conditional rules, several other adjustments have been made to adjust PI calculations for Swedish conditions:

1.) The main transport mechanisms are surface runoff and subsurface drainage. The partition between these two pathways is based on field slope and the soil's permeability. Subsurface drainage is then divided into matrix and preferential flow, and the division is based on soil structure and the soil's saturated hydraulic conductivity. The distribution into different pathways is made in such a way that the sum of all transport mechanisms always equals 1 . Matrix flow is always present and its value varies between 0.2 and 1 . Consequently, values for preferential flow and surface runoff vary between 0.0 and 0.8 .

2.) Calculations of risk of UP and RP are made separately to account for differences in mobility of these two $\mathrm{P}$ forms in the above-mentioned $\mathrm{P}$ transport pathways. It is assumed that matrix flow does not contribute to transport of UP.

3.) Erosion is treated as a source of UP rather than as a transport mechanism. Erosion calculated with the RUSLE equation is combined with the amounts of $\mathrm{P}$ present on the eroded soil material (P enrichment ratio) to describe the sources of UP. An average UP concentration on eroded soil material has been calculated from data measured in water samples from 10 observation fields included in a long-term water-quality monitoring programme. 


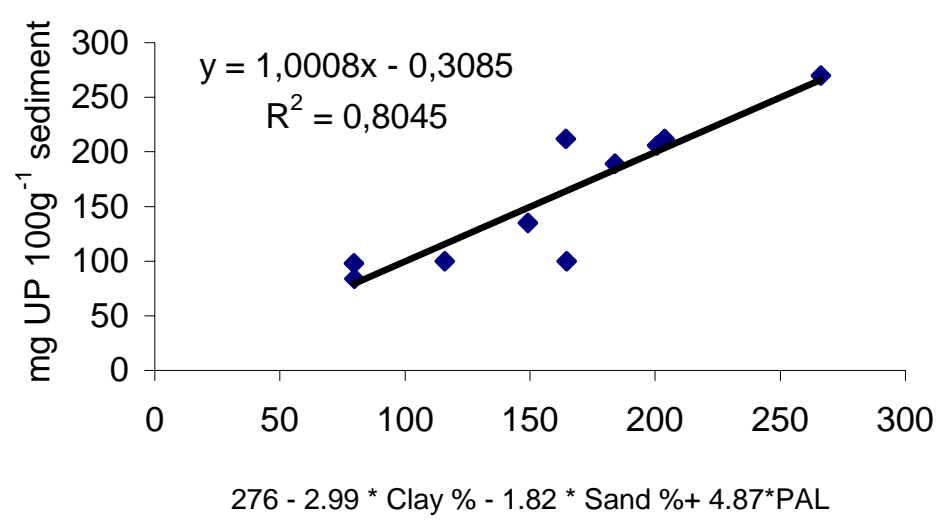

Figure 1. Concentrations of UP on eroded material as a function of texture and PAL

The calculated average values were correlated to different soil properties and the best correlation has been found with the percentage of clay and sand, and soil P content measured with PAL. The regression equation is showed in Figure 1. The calculated values are in PI ranked in classes with ranking values between 1-16 and then multiplied with the erosion value received from RUSLE calculations to obtain part of the total value for UP sources.

4.) Risk of losses of RP is calculated using the degree of the P saturation concept. Börling (2003) found a linear relationship between the concentrations of the RP released by $\mathrm{CaCl}_{2}$-extractable $\mathrm{RP}$ and the degree of $\mathrm{P}$ saturation calculated as the ratio between the $\mathrm{P}-\mathrm{AL}$ value and a single-point $\mathrm{P}$ sorption index (PSI). This relationship has been calculated for all available soil samples (Figure 2) and used for PI calculations.

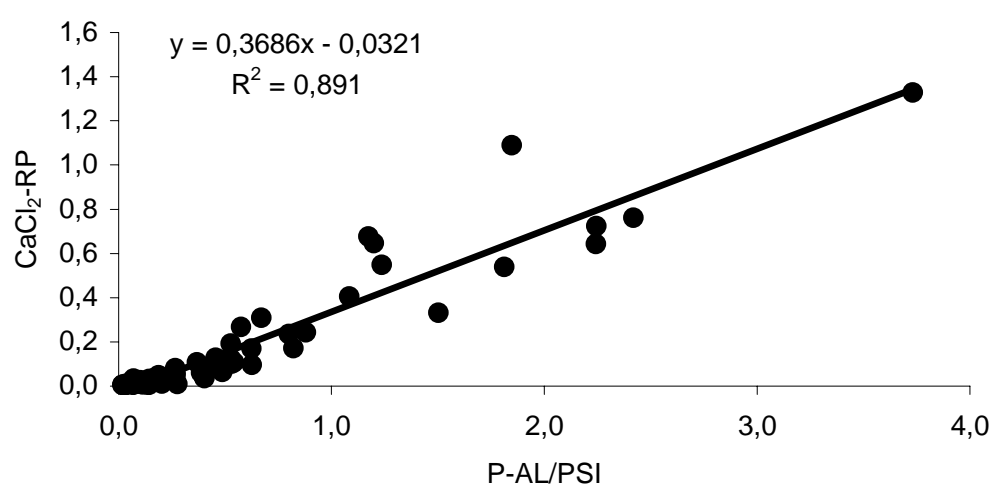

Figure 2. $\mathrm{CaCl}_{2}$-extractable $\mathrm{RP}$ as a function of $\mathrm{P}$ saturation degree

5.) The measured data for PSI are not widely available and an alternative way of calculating PSI is also suggested. However, the suggested 
equation is based on a limited number of soils and, therefore, the user should use measured values of PSI whenever possible. The DPS is in PI calculated for both topsoil and subsoil. The DPS of subsoil (which is usually lower) is used to calculate the risk of RP losses through matrix flow, whereas topsoil DPS is used for preferential flow and surface runoff, assuming that the P sorption sites in these cases will be by-passed.

6.) The other $P$ sources originate from $P$ additions. The apportionment of $\mathrm{P}$ additions into UP and RP depends on the P sorption capacity of the soil measured by the single-point $\mathrm{P}$ addition (Börling et al., 2003). Figure 3 shows the relationship between $\mathrm{RP}$ in $\mathrm{CaCl}_{2}$ solution and PSI.

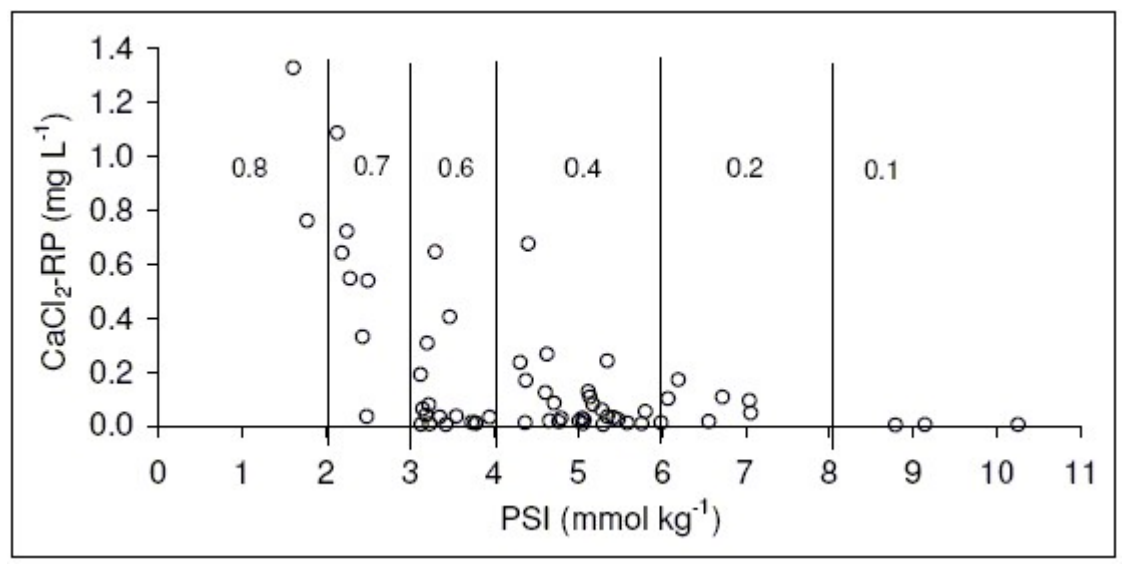

Figure 3. $\mathrm{CaCl}_{2}$-extractable RP as a function of PSI

A higher PSI value results in lower RP concentrations and a lower RP apportionment factor. The UP apportionment factor equals 1-RP factor, i.e. higher PSI values increase the UP part of $P$ additions.

Several other factors are also included in PI calculations. Presence of buffer strips reduces the risk of UP in surface runoff but has no effects on other transport mechanisms or RP transport. Tile drains and presence of inlets for collection of surface runoff increase the field connectivity and thereby the risk of $\mathrm{P}$ losses. Occurrence of water ponding conditions increase the risk of RP losses through preferential flow.

As mentioned earlier, one of the main advantages of PI should be its simplicity. Introduction of conditional rules, new parameters and relationships, as well as the distinction between P forms do make PI calculations more complicated. However, the input data requested for calculations have not increased significantly. Basically, PSI measurements are the only new parameter values necessary for PI calculations and an option for approximation of PSI value is also given to the user. Hence, to facilitate calculations and avoid procedural mistakes, an interface in the form of a Visual Basic application has been built (Figure 4). 


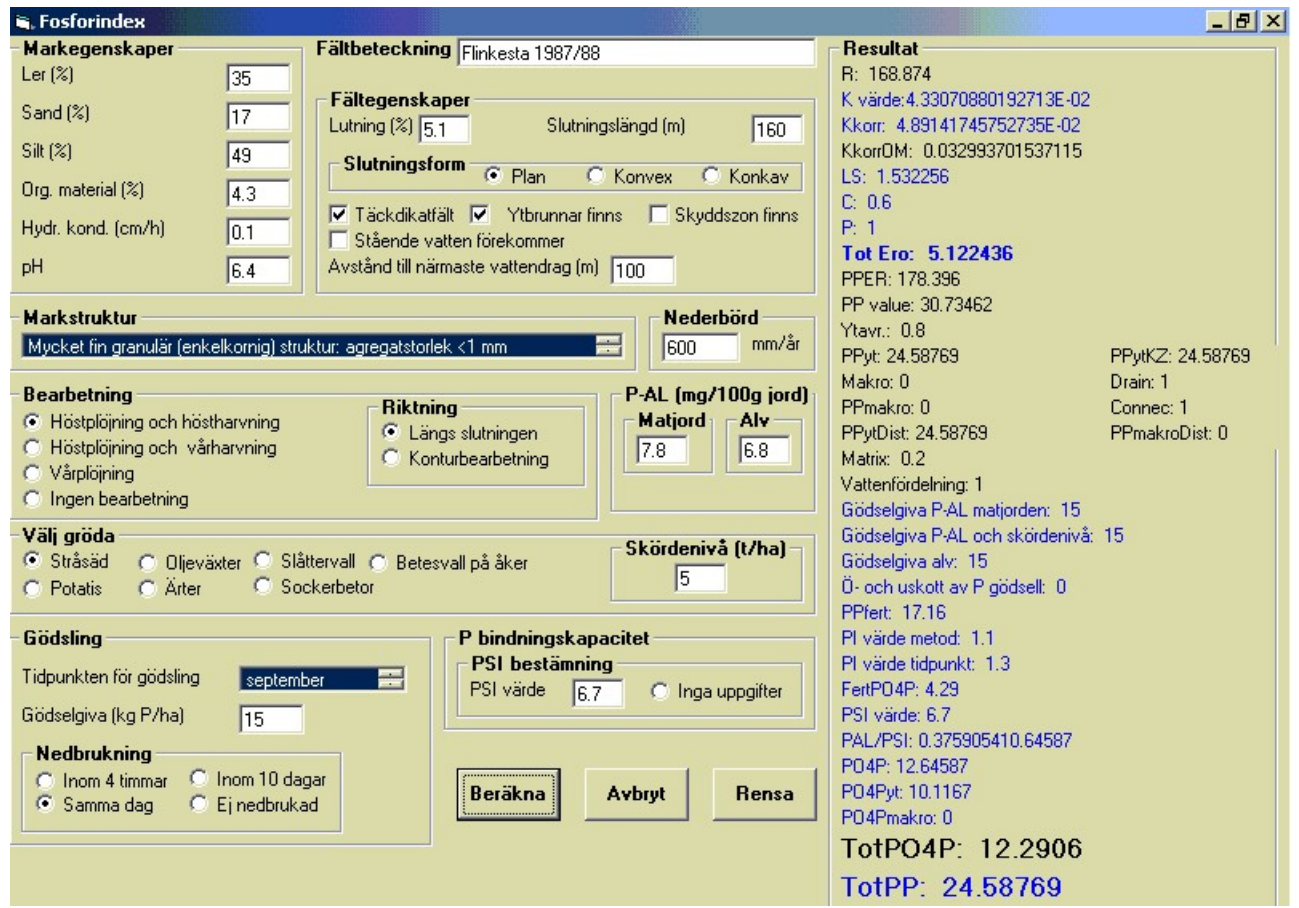

Figure 4. Screen image of VB application for PI calculations

The User should be able to calculate and see different PI values after filling in the site-specific input-data. The results (Fig. 4 righthand side) are also written to a text file, in which a more detailed description of all results is given. Besides PI calculations, the user can compare its P fertilizing strategy to recommendations based on crop, expected yield and PAL status in the top- and subsoil. Presented Swedish PI will be calibrated and validated using the measured transports of different $\mathrm{P}$ forms from fields included in a nationwide water quality monitoring programme.

\section{References}

Alström, K. \& Bergman, A. (1990), Water erosion on arable land in southern Sweden. In: Boardman, J., Foster, I.D.L. \& Dearing, J.A. (eds.). Soil erosion on agricultural land. John Wiley \& Sons Ltd, Chichester. pp. 107-117.

Börling, K. (2003), Phosphorus sorption, accumulation and leaching. Doctoral thesis. Acta Universitatis Agriculturae Sueciae. Agraria 428. Uppsala, Sweden.

Djodjic, F. (2001), Displacement of phosphorus in structured soils. Doctoral thesis. Acta Universitatis Agriculturae Sueciae. Agraria 283. Uppsala, Sweden.
Djodjic, F., Montas, H., Shirmohammadi, A., Bergström, L. \& Ulén, B. (2002), A decision support system for phosphorus management at a watershed scale. Journal of Environmental Quality, vol. 31, pp. 937-945.

Gburek, W.J., Sharpley, A.N., Heathwaite, L. \& Folmar, G.J. (2000), Phosphorus management at the watershed scale: A modification of the phosphorus index. Journal of environmental quality, vol. 29, pp. 130-144.

Lemunyon, L.E. \& Gilbert, R.G. (1993), The concept and need for a phosphorus 
assessment tool. Journal of production agriculture, vol. 6, pp. 483-496.

SCB (1997), Jordbruksstatistisk årsbok

(Yearbook of Agricultural statistics). Statistiska Centralbyrån, Stockholm.
Ulén, B., Johansson, G. \& Kyllmar, K. (2001), Model predictions and longterm trends in phosphorus transport from arable lands in Sweden. Agricultural Water Management, vol. 49, pp. 197-210. 


\title{
3.8 The VIHMA model - assessing measures to reduce erosion and $\mathrm{P}$ loss from agricultural land in Finland
}

\author{
Markku Puustinen and Sirkka Tattari \\ Finnish Environment Institute, P.O. Box 140, FIN-00251 Helsinki, Finland, \\ markku.puustinen@ymparisto.fi
}

\section{Introduction}

Reduction of the nutrient loading from agriculture requires information on the effects of the protective measures and, above all, wide-ranging application of fresh know-how in practice. Good regional and nationwide coincidence of the protective measures implemented by the farmers and the environmental targets set by the society should be set as a major objective. The decision-making of the farmers is affected by the available information on the load-reducing measures, economical effects of the implementation of the measures and personal, case-specific interests.

Nationally, the goals for the reduction of agricultural loading are determined by the "Water Protection Targets for 2005" issued by the Finnish Government in 1998. As a member state of the EU, Finland is obliged to meet the regulations restricting the use of fertilizers (EU Nitrates Directive) and obliged to carry out catchment-scale water protection activities (EU Water Framework Directive). Without question, public resources allocated for environmental protection should be used efficiently. In the targeting, the appropriateness of the most cost-efficient measures should be checked first, and then gradually change over to the less cost-efficient ones. This kind of approach minimizes the total costs that the achievement of the load reduction targets demands.

The main goal of the VIHMA project is to create a system for

i) the assessment of the volume and distribution of loading from a catchment

ii) the prioritising of the protective measures according to cost-efficiency and

iii) the assessment of the significance of different hydrological years on the efficiency of the measures

In the VIHMA system the most common tillage and cultivation practices, buffer zones, subsurface drainage solutions, constructed wetlands and sedimentation basins can be compared and ranked within a single catchment. The system is being prepared jointly by several Finnish institutes: the Finnish Environment Institute, Agrifood Research Finland, Helsinki University of Technology, The Finnish Field Drainage Center and two Regional Environment Centres. 


\section{Materials and methods}

Principle of the VIHMA system and the protective measures for the comparisons

Firstly, the present state of the amounts and distributions of loading (erosion, phosphorus (P), nitrogen $(\mathrm{N})$ ) is assessed by field categories. This assessment is based on the properties of the cultivated areas of the catchment and on the results of field experiments.

Field categories are formed from three variables: field slope (4 classes), soil type (4 classes) and tillage practice (6 classes). Hence, the total number of field categories is 4 × 4 × $6=96$. Moreover, P-status and the drainage condition of the fields are included as additional variables for more accurate description of the fields. The classification and the units of the variables are presented in Table 1.

Table 1. Classification of the variables of the VIHMA system

\begin{tabular}{ll}
\hline Variable & Classification and/or unit \\
\hline Slope & $<0.5 \%, 0.5-1 \%, 1-3 \%,>3 \%$ \\
Soil type & Clay, Silt, Coarse, Organic \\
Cultivation & Intensive autumnal tillage, Reduced autumnal tillage, Crop covered, Crop \\
& covered with buffer zone, Reduced spring tillage, Permanently crop covered \\
P-status & $\mathrm{mg} \mathrm{P} \mathrm{I}^{-1}$ in soil \\
Condition of drainage & Surface/subsurface runoff, age in years \\
\hline
\end{tabular}

Based on long-term field experiments, typical loading figures (erosion, particulate $\mathrm{P}$, total $\mathrm{N}$, nitrate-N) are tabulated. The loading of dissolved reactive $\mathrm{P}$ (DRP) is determined - and the particulate $\mathrm{P}$ loading corrected - according to the P-status of the cultivated soil layer. The proportions of surface runoff and subsurface drainage flow are determined according to the age of the drainage system, which is also used to correct the figures of erosion and particulate $P$ loading.

Given the requirements of the recipient body of water, the VIHMA system is able to indicate the load reduction effects and cost-efficiency of each protective measure. The most cost-efficient measures will then be chosen for implementation. The number of the selected measures will be determined according to how much load reduction is cumulatively needed to reach the target state of the recipient body of water.

The measures included in the VIHMA system comprise common cultivation methods, drainage systems, buffer zones and constructed wetlands. The cultivation methods are classified according to how they affect the characteristics of field surface. The key factors are date and intensity of tillage, vegetation cover during winter and the stability of the vegetation cover. The differences in their effects on loading are represented by coefficients based on field experiments. The change from the prevailing state achieved by different measures is calculated according to these coefficients. Tabulation of the loading figures and the coefficients for differ- 
ent circumstances (the 96 categories) is under preparation. The effects of buffer zones are described by reduction percentages and those of constructed wetlands by dimensioning-dependent reduction percentages.

\section{Experimental fields}

Appropriate data exist from the experimental fields of Aurajoki (11 y, Puustinen et al., 2004), Kotkanoja (20 y, Turtola, 1999), Liperi (10 y), Toholampi (10 y), and Lintula (10 y). According to the available cultivation and tillage data from 1980-2000, results of Hovi (a "small drainage basin") from these 20 years were also examined. As for buffer zones, the data came from the experimental fields of Lintupaju (10 y) and Aurajoki (4). The material from constructed wetlands was collected from the 1- to 3-year experiments made at the Hovi, Flytträsk, Alastaro and Rautalampi wetlands. The data of drainage systems came from the Sjökulla experimental field. The information on the active purification of agricultural drainage waters by iron and aluminum was based on the experiments performed by Agrifood Research Finland (MTT).

\section{Hydrological years}

The hydrological classification of the experimental periods (from September through May) was based on cumulative snow water equivalents (SWEs) during the experimental periods. The SWE data were collected biweekly from so-called snow lines maintained by the Finnish environmental authorities. The daily values, and the time series showing the variation of SWE, were obtained by the HBV-model as described by Tattari et al. (2003). Based on the visual classification of the shape of the SWE time series curves and on the SWE magnitude, the experimental periods (winters) were divided into three classes: a cold winter rich in snow (Type I), a cold winter with average amount of snow (Type II) and a mild winter poor in snow (Type III). Because of the scarcity of the winters falling in the Type I, the Types I and II were combined and titled "Arctic" winters. The winters of Type III were named as "Mild". The average runoff and loading figures were calculated from the empirical data for both winter types. The data of the nearest snow line was used for each experimental field.

\section{Costs incurred by the protective measures}

Costs are calculated for each protective measure. Based on the costs, net yield matrices were prepared to describe the changes in farm-level costs when changing over from one protective measure to another. The cost calculations were made by each protective measure separately. The private economical examination points out the cost-efficiencies on the basis 
of real farm-level costs. Common direct and indirect costs as well as the differences in productivity were taken into account in this examination. The examinations were made from both private and public economical points of view.

\section{A demonstration of the VIHMA system}

Here, the use and results of the VIHMA system are demonstrated by applying them to a theoretical catchment with an area of 1000 ha $(100 \%$ arable) and having clay as the soil type. The average slope of the fields is distributed as follows: $35 \%$ in the class $<0.5 \%, 20 \%$ in the class $0.5-1 \%$, $25 \%$ in the class $1-3 \%$ and $20 \%$ in the class $>3 \%$. This classification corresponds to the average distribution of the Finnish arable fields. Cultivation practices are distributed as follows: $45 \%$ with autumn ploughing, $15 \%$ with autumn ploughing followed by preparation of seedbed and simultaneously sown winter wheat, $5 \%$ with stubble cover over the winter, $5 \%$ with autumnal direct sowing and $30 \%$ with grass ley. Cost efficiencies of constructed wetlands (CW), buffer zones (BZ), stubble (ST), direct sowing (DS) and grass ley (GL) are compared.

CW I is large (5\% of its catchment) and constructed by excavation. Its investment cost (12 $500 €$ ) is divided over 10 years and to the annual cost is added the expenses incurred by the CW maintenance (100 €/y) and the agri-environmental special subsidy (450 €) is subtracted. This results in an annual cost to the farmer of $900 €$. CW II is of similar size (5\% of its catchment) but made by damming. In this case, the investment cost is fundamentally lower (3500 €), which - counting maintenance costs and the subsidy - leads to $0 €$ annual expenditure for the farmer. CW III is also made by damming and is sized according to the minimum requirements: its area is $2 \%$ of its catchment area. Investment and maintenance costs, as well as the farmer's expenditure ( $0 €)$, are equal to CW II. The public costs are in all three cases equal to the subsidy (450€). Owing to their longer water retention time, CW I and CW II retain P and suspended solids much more efficiently than CW III.

BZ I is established adjacent to a field planted with winter wheat and BZ II adjacent to one with sugar beet. In both cases the annual costs, which are covered by the agri-environmental special subsidy, are formed by the loss of income due to the lost productive area occupied by the BZ. The annual cost to the farmer is $15 € / \mathrm{ha} / \mathrm{y}$ for BZ I and $80 € / \mathrm{ha} / \mathrm{y}$ for BZ II.

Here, ST represents the change from "traditional" autumn ploughing with sowing in spring to the practice of leaving stubble on the field over the winter and tillage by a cultivator in spring (annual cost to the farmer $23 € / h a / y)$. DS means here that winter wheat sown after autumn ploughing is replaced by direct autumn sowning of winter wheat (the annual farmer's cost $23 € / \mathrm{ha} / \mathrm{y}$ ). In the GL alternative grass ley is left over the 
field for the whole year, a neighbouring farm does the harvesting and the main farm receives the subsidy (annual cost to the farmer $158 € / \mathrm{ha} / \mathrm{y}$ ).

\section{Preliminary results and discussion}

Tables 2-4 present the average rate of erosion and the loading of total $\mathrm{P}$ and particulate $\mathrm{P}$ from the fields in a sample catchment during a typical, arctic winter for slope and cultivation practice. The load values - each of which includes the total area of the respective field class - show the distribution of the total loading (bottom righthand corner) in the catchment. The figures reveal the most critical sources of loading in the catchment and thus help to make tentative evaluations of allocating the protective measures.

Table 2. Erosion (kg) in different field classes.

\begin{tabular}{|c|c|c|c|c|c|c|}
\hline \multirow[t]{2}{*}{ Slope } & \multicolumn{5}{|c|}{ Cultivation practice } & \multirow{2}{*}{$\begin{array}{r}\text { Specific load } \\
\left(\mathrm{kg} \mathrm{ha}^{-1}\right)\end{array}$} \\
\hline & Ploughing & W.wheat & Stubble & Direct sowing & Grass ley & \\
\hline$<1 \%$ & 34300 & 9600 & 3000 & 2400 & 8250 & 105 \\
\hline $1-3 \%$ & 77700 & 26000 & 7800 & 6250 & 20250 & 550 \\
\hline$>3 \%$ & 119700 & 31500 & 6000 & 5100 & 33000 & 975 \\
\hline $\begin{array}{l}\text { Specific load } \\
\left(\mathrm{kg} \mathrm{ha}^{-1}\right)\end{array}$ & 520 & 450 & 320 & 260 & 205 & $\begin{array}{r}\text { Total } \\
390150 \mathrm{~kg}\end{array}$ \\
\hline
\end{tabular}

Table 3. Total $P$ loading $(\mathrm{kg})$ in different field classes.

\begin{tabular}{|c|c|c|c|c|c|c|}
\hline \multirow[t]{2}{*}{ Slope } & \multicolumn{5}{|c|}{ Cultivation practice } & \multirow{2}{*}{$\begin{array}{r}\text { Specific load } \\
\left(\mathrm{kg} \mathrm{ha}^{-1}\right)\end{array}$} \\
\hline & Ploughing & W.wheat & Stubble & Direct sowing & Grass ley & \\
\hline$<1 \%$ & 201 & 58 & 15 & 15 & 165 & 0.83 \\
\hline $1-3 \%$ & 81 & 28 & 9 & 11 & 62 & 0.76 \\
\hline$>3 \%$ & 250 & 68 & 20 & 28 & 110 & 2.39 \\
\hline $\begin{array}{l}\text { Specific load } \\
\left(\mathrm{kg} \mathrm{ha}^{-1}\right)\end{array}$ & 1.20 & 1.03 & 0.84 & 1.05 & 1.12 & $\begin{array}{r}\text { Total } \\
1122 \mathrm{~kg}\end{array}$ \\
\hline
\end{tabular}

Table 4. Particulate $P$ loading $\left(\mathrm{kg} \mathrm{ha}^{-1}\right)$ in different field classes.

\begin{tabular}{|c|c|c|c|c|c|c|}
\hline \multirow[t]{2}{*}{ Slope } & \multicolumn{5}{|c|}{ Cultivation practice } & \multirow{2}{*}{$\begin{array}{r}\text { Specific load } \\
\left(\mathrm{kg} \mathrm{ha}^{-1}\right)\end{array}$} \\
\hline & Ploughing & W.wheat & Stubble & Direct sowing & Grass ley & \\
\hline$<1 \%$ & 71.0 & 26.4 & 6.9 & 6.9 & 23.1 & 0.24 \\
\hline $1-3 \%$ & 70.5 & 24.0 & 8.0 & 7.3 & 40.4 & 0.60 \\
\hline$>3 \%$ & 201.6 & 53.4 & 10.7 & 0.9 & 55.8 & 1.65 \\
\hline $\begin{array}{l}\text { Specific load } \\
\left(\mathrm{kg} \mathrm{ha}^{-1}\right)\end{array}$ & 0.77 & 0.69 & 0.49 & 0.44 & 0.40 & Total $615 \mathrm{~kg}$ \\
\hline
\end{tabular}

Allocation of the protective measures should be based primarily on local conditions. Some of the potential measures may be inappropriate for the local conditions, thus leaving the most practicable ones for the final choice. Here, the choice is based on private cost-efficiency. From a farmer's view, the most cost-efficient choices of the given alternatives would be CWs II and III, because they would, owing to the agrienvironmental special subsidy, be cost-free for the farmer (Table 5). CW 
I would become very expensive for a farmer because of the high construction costs, of which the agri-environmental special subsidy would only cover a minor part.

BZ I and ST are cost-efficient measures against erosion, but not so cost-efficient against total P. For ST, this is due to the increased loading of dissolved P. BZ II is not a very cost-efficient choice for a farmer because of the high losses of income. From a purely environmental perspective BZ II adjacent to a sugar beet field would be a very sustainable choice. The cost-efficiency of DS is weakened by its high costs to the farmer and the increased transport of dissolved P. Similar reasons also apply to the GL alternative for farms with crop husbandry (Table 5).

Here, the public costs are the maximum agri-environmental special subsidies allowed for CWs and BZs, which make these two protective measures attractive to a private -economy, particularly in the case of CW I, CW II and BZ I. As for cultivation practices, public costs cannot be given here because of the production-linked, acreage-based "environmental subsidies" that form an important part of the present, contractual agriculture. Hence, the cost-efficiency of a cultivation practice is highly dependent on the line of production of the farm and on what practice is to be changed.

Table 5. Cost-efficiencies $(€ / \mathrm{kg})$ of the protective measures.

\begin{tabular}{lllll}
\hline Protective measure & Erosion/private & Tot.P/private & Erosion/public & Tot.P/public \\
\hline Constr.wetland I & $0.17-0.27$ & $67-95$ & $0.09-0.14$ & $34-48$ \\
Constr.wetland II & 0 & 0 & $0.09-0.14$ & $34-48$ \\
Constr.wetland III & 0 & 0 & $0.20-0.32$ & $79-113$ \\
Buffer zone I & $0.01-0.02$ & $4-8$ & $0.05-0.09$ & $23-43$ \\
Buffer zone II & $0.05-0.09$ & $23-43$ & $0.05-0.09$ & $23-43$ \\
From ploughing to ST & $0.01-0.03$ & $10-35$ & & \\
From ploughing to DS & $0.04-0.09$ & $280-$ & & \\
From ploughing to GL & $0.07-0.19$ & $54-270$ & & \\
\hline
\end{tabular}

\section{Conclusions}

The cost-efficiency of a protective measure for the mitigation of the agricultural loading to surface waters depends on its ability to reduce the loading compared with the preceding conditions, as well as the net costs due to the change. The net costs are also affected by the possible losses of productive area and - hence - income when a BZ is established or a cultivation practice changed. The examinations should be based on actual farms and their lines of production. Different farm types and the choices available in terms of protective measures lead to a myriad of comparable combinations of measures within a catchment. With the VIHMA system these comparisons can be made. The evaluations of cost-efficiency from both a private and public economic viewpoint makes it possible to realistically assess the needs of allocation of environmental subsidies. 


\section{References}

Puustinen, M., Koskiaho, J. \& Peltonen, K. (2004), Influence of cultivation methods on suspended solids and phosphorus concentrations in surface runoff on sloped fields. Agriculture, Ecosys- tems and the Environment, vol. 105(4), pp. 565-579.

Turtola, E. (1999), Phosphorus in surface runoff and drainage water affected by cultivation practices. Diss. University of Helsinki. 108 pp. 


\title{
3.9 Modifying and evaluating a P index for Denmark
}

\author{
Hans Estrup Andersen and Brian Kronvang
}

National Environmental Research Institute, Department of Freshwater Ecology, Vejlsøvej 25, DK-8600 Silkeborg, Denmark

\section{Introduction}

The aim of our study was to initiate the development of a P loss assessment tool suitable for Danish conditions, and which water district managers can easily adopt. An assessment of P losses from agricultural land is, however, not straightforward. Within any catchment the losses of dissolved and particulate $\mathrm{P}$ are critically dependent on a suite of combined source, soil and transport factors that varies considerably both in space and time (Gburek et al., 2000; Kronvang et al., 2002). We chose to base our work on an existing risk assessment tool, the P Index. However, the P Index is originally developed for areas where soil erosion and surface runoff are major $\mathrm{P}$ loss pathways. The $\mathrm{P}$ Index therefore needs to be modified to local or regional conditions in order to incorporate all potential P loss pathways. Even though the P Index has been widely applied for managing $\mathrm{P}$ losses at the farm and field level in the USA, no calibration or validation has been conducted at the catchment scale (Sharpley et al., 2002).

In this study we applied the Pennsylvania P Index (see Sharpley et al., 2003 for an exhaustive description) on the $1000 \mathrm{~km}^{2}$ Odense Fjord catchment in Denmark. Subsequently, we applied a version of the P Index modified to reflect Danish conditions on the same catchment. In order to test the $\mathrm{P}$ indices we examined their capability to rank measured annual diffuse P export from twelve subcatchments within the Odense Fjord catchment.

\section{Modifying a P Index for Danish conditions}

Due to the Danish topography, low intensity rainfall regime and soils generally only moderately erodible (e.g. K-factor for the Odense Fjord catchment $=0.13-0.24$ ) soil erosion and surface runoff are not considered major P loss pathways in Denmark (Rubæk et al., 2003). Andersen et al. (2005), on the other hand, has demonstrated that tile drains are an important pathway for P losses from fields to surface waters in Denmark. A Danish P Index should also consider the risk of P leaching. Our strategy for modifying the $\mathrm{P}$ Index for Danish conditions was to keep with the Pennsylvania P Index and make modifications only where justified in Danish experience. 
Part A - Screening Tool. Tile drains are connected to receiving surface waters. Thus P lost from the root zone to tile drains will eventually end up in surface waters. Therefore the Screening Tool is modified so that all fields on a tile drainage system are included in the $\mathrm{P}$ Index calculation regardless of distance to receiving waters (Table 1).

Part B - Source Factors. No changes compared to the original Pennsylvania P Index.

Part C - Transport Factors. A new soil type dependent factor, the Leaching Potential, is introduced in the Danish P Index, as also suggested by Coale et al. (2002). This factor expresses the risk of $P$ from the root zone being transported to tile drains or to a shallow groundwater table. Loamy soils are attributed a higher weight in the Danish P Index than sandy soils due to the risk of macropore flow in loamy, structured soils. Even though the subsoil of loamy soils may have a large unused $\mathrm{P}$ binding capacity (Rubæk et al., 2003), this might be shortcut by macropores conveying both particulate and dissolved $\mathrm{P}$ from the $\mathrm{P}$ rich topsoil directly to tile drains or to a shallow groundwater table. The $\mathrm{P}$ binding capacity of soils is almost exclusively associated to the mineral fraction. Thus, the P binding capacity of organic soils is normally very low (Svendsen and Kronvang, 1991). Danish studies have shown large P losses from tile drained organic soils (review in Rubæk et al., 2003). Consequently, organic soils are assigned the highest risk of P leaching in the Danish P Index (Table 1). It has been demonstrated in numerous experiments that even small buffer strips between a field and receiving waters can effectively retain large amounts of TP being mobilised from the field by erosion or surface runoff (e.g. Uusio-Kämppä, 2000). These experiments have, however, been carried out under ideal conditions. Under natural conditions fine sediments enriched in P may pass through the buffer strip, e.g. where the buffer strip is buried by deposited sediments in depressions in the landscape. Danish field based research (Kronvang et al., 2004) has shown that the risk of sediments passing through a buffer strip is a function partly of the width of the buffer strip and partly of the magnitude of the uphill erosion. This result was incorporated into the Danish P Index by dividing the magnitude of erosion into three classes, 'negligible', 'medium', and 'high', the terms referring to a Danish context. The distinction between 'negligible' and 'medium' is a soil loss of $0.084 \mathrm{t} \mathrm{ha}^{-1} \mathrm{yr}^{-1}$, and between 'medium' and 'high' a soil loss of $1.008 \mathrm{t} \mathrm{ha}^{-1} \mathrm{yr}^{-1}$. Due to the uncertainty in the GIS themes, we were restrained to distinguish only between buffer strips $=2 \mathrm{~m}$ (mandatory in Denmark) and buffer strips $>2 \mathrm{~m}$. Modified Connectivity is calculated after Kronvang et al., (2004) expressing the probability (between 0 and 1 ) of eroded sediments passing through the buffer strip. 
Table 1. The modified Danish P Index.

\begin{tabular}{|c|c|c|c|c|c|c|c|}
\hline \multicolumn{7}{|c|}{ Evaluation Category } & \\
\hline \multicolumn{2}{|c|}{$\begin{array}{l}\text { Soil Test } P \\
\text { Contributing Distance } \\
\text { Contributing Distance }\end{array}$} & \multicolumn{3}{|c|}{$\begin{array}{l}>200 \mathrm{mg} \mathrm{P} \mathrm{kg}^{-1} \\
<45 \mathrm{~m} \\
>45 \mathrm{~m} \text { AND field artificially drained }\end{array}$} & \multicolumn{2}{|c|}{$\begin{array}{l}\text { If yes to either factor } \\
\text { then proceed to Part B }\end{array}$} & \\
\hline \multicolumn{8}{|c|}{ Part B - Source factors } \\
\hline \multirow[t]{2}{*}{ Soil test $\mathrm{P}$} & \multicolumn{7}{|c|}{ Soil Test $\mathrm{P}\left(\mathrm{mg} \mathrm{P} \mathrm{kg}^{-1}\right)$ (Olsen-P translated to Mehlich-III-P) } \\
\hline & \multicolumn{7}{|c|}{ Soil Test $\mathrm{P}$ Rating $=0.20^{*}$ Soil Test $\mathrm{P}\left(\mathrm{mg} \mathrm{P} \mathrm{kg}^{-1}\right)$ for mineral soil } \\
\hline Fertilizer $\mathrm{P}$ rate & \multicolumn{7}{|c|}{ Fertilizer $\mathrm{P}\left(\mathrm{kg} \mathrm{ha}^{-1}\right)$} \\
\hline Manure $\mathrm{P}$ rate & \multicolumn{7}{|c|}{ Manure $\mathrm{P}\left(\mathrm{kg} \mathrm{ha}^{-1}\right)$} \\
\hline \multirow[t]{2}{*}{$\begin{array}{l}\text { P source } \\
\text { application } \\
\text { method }\end{array}$} & \multicolumn{2}{|c|}{$\begin{array}{l}0.2 \\
\text { Placed or } \\
\text { injected } 5 \mathrm{~cm} \\
\text { or more deep }\end{array}$} & $\begin{array}{l}0.4 \\
\text { incorporated } \\
<1 \text { week }\end{array}$ & $\begin{array}{l}0.6 \\
\text { incorporated >1 } \\
\text { week or not incorpo- } \\
\text { rated April-October }\end{array}$ & \multicolumn{2}{|c|}{$\begin{array}{l}0.8 \\
\text { Incorporated }>1 \\
\text { week or not incorpo- } \\
\text { rated Nov.-March }\end{array}$} & $\begin{array}{l}1.0 \\
\text { Surface applied to } \\
\text { frozen or snow } \\
\text { covered soil }\end{array}$ \\
\hline & \multicolumn{7}{|c|}{ Fertilizer Rating $=$ Rate $\times$ Method } \\
\hline \multirow[t]{3}{*}{$\begin{array}{l}\text { Manure P } \\
\text { availability }\end{array}$} & \multicolumn{3}{|c|}{$\begin{array}{l}0.5 \\
\text { Treated manure/Biosolids }\end{array}$} & $\begin{array}{l}0.8 \\
\text { Dairy }\end{array}$ & \multicolumn{2}{|c|}{$\begin{array}{l}1.0 \\
\text { Poultry/Pigs }\end{array}$} & \\
\hline & \multicolumn{7}{|c|}{ Manure Rating $=$ Rate $\mathrm{x}$ Method $\mathrm{x}$ Availability } \\
\hline & \multicolumn{7}{|c|}{ Source Factor $=$ Soil Test $\mathbf{P}$ Rating + Fertilizer Rating + Manure Rating } \\
\hline \multicolumn{8}{|c|}{ Part C - Transport factor } \\
\hline Erosion & \multicolumn{7}{|c|}{ Soil Loss (tonnes ha ${ }^{-1}$ ) } \\
\hline $\begin{array}{l}\text { Runoff } \\
\text { potential }\end{array}$ & \multicolumn{2}{|c|}{$\begin{array}{l}0 \\
\text { Very low }\end{array}$} & $\begin{array}{l}2 \\
\text { Low }\end{array}$ & $\begin{array}{l}4 \\
\text { Medium }\end{array}$ & $\begin{array}{l}6 \\
\text { High }\end{array}$ & & $\begin{array}{l}8 \\
\text { Very high }\end{array}$ \\
\hline $\begin{array}{l}\text { Leaching } \\
\text { Potential }\end{array}$ & \multicolumn{3}{|c|}{$\begin{array}{l}2 \\
\text { sandy soil }\end{array}$} & $\begin{array}{l}4 \\
\text { loamy soil }\end{array}$ & & \multicolumn{2}{|c|}{$\begin{array}{l}6 \\
\text { organic soil }\end{array}$} \\
\hline $\begin{array}{l}\text { Subsurface } \\
\text { Drainage }\end{array}$ & \multicolumn{3}{|c|}{$\begin{array}{l}0 \\
\text { No artifical drains }\end{array}$} & $\begin{array}{l}1 \\
\text { Few ditches or tile c } \\
\text { with wide spacing }\end{array}$ & Irains & \multicolumn{2}{|c|}{$\begin{array}{l}2 \\
\text { Field is on a tile drainage } \\
\text { system }\end{array}$} \\
\hline $\begin{array}{l}\text { Contributing } \\
\text { Distance }\end{array}$ & \multicolumn{3}{|l|}{$\begin{array}{l}8 \\
<45 \mathrm{~m}\end{array}$} & $\begin{array}{l}0 \\
>45 \mathrm{~m}\end{array}$ & & & \\
\hline \multirow[t]{2}{*}{$\begin{array}{l}\text { Modified } \\
\text { Connectivity }\end{array}$} & \multicolumn{3}{|c|}{$\begin{array}{l}0.03 \\
\text { Riparian buffer }=2 \mathrm{~m} \\
\text { Erosion Negligible }\end{array}$} & $\begin{array}{l}0.24 \\
\text { Riparian buffer }=2 \\
\text { Erosion Medium }\end{array}$ & & $\begin{array}{l}0.65 \\
\text { Riparian b } \\
\text { Erosion } \mathrm{Hi}\end{array}$ & $\begin{array}{l}\text { uffer }=2 \mathrm{~m} \\
\text { ligh }\end{array}$ \\
\hline & \multicolumn{3}{|c|}{$\begin{array}{l}0.02 \\
\text { Riparian buffer }>2 \mathrm{~m} \\
\text { Erosion Negligible }\end{array}$} & $\begin{array}{l}0.20 \\
\text { Riparian buffer> } 2 n \\
\text { Erosion Medium }\end{array}$ & & $\begin{array}{l}0.59 \\
\text { Riparian b } \\
\text { Erosion } \mathrm{Hi}\end{array}$ & $\begin{array}{l}\text { uffer }>2 \mathrm{~m} \\
\text { ligh }\end{array}$ \\
\hline \multicolumn{8}{|c|}{$\begin{array}{l}\text { Transport Factor }=\left[(\text { Erosion }+ \text { Runoff Potential }+ \text { Contributing Distance })^{\star} \text { Modified Connectivity }+\right. \\
(\text { Sub-surface Drainage }+ \text { Leaching Potential }] / 22\end{array}$} \\
\hline \multicolumn{8}{|c|}{ Phosphorus Index Value $=\mathbf{2} \times$ Source Factor $\mathrm{x}$ Transport Factor } \\
\hline
\end{tabular}

\section{Evaluating the Danish P Index}

For twelve subcatchments within the Odense Fjord catchment data on diffuse total P (TP) were available for 1998 - 2002. The catchments represent a large range in catchment sizes, extent of arable land, and TP export. A catchment $\mathrm{P}$ Index value was calculated for each of the twelve subcatchments with measured diffuse TP lossses: For each subcatchment the products of P Index value and field area were summed and divided by total subcatchment area. A regression analysis between the calculated subcatchment $\mathrm{P}$ Index values and the subcatchment TP losses was carried out (Table 2 and Fig. 1). Catchment vulnerability to $\mathrm{P}$ loss in runoff as 
calculated by the Danish P Index was closely related to actual measured losses $\left(\mathrm{R}^{2}=0.79-0.85\right)$ and with distinctly better coefficients of determination than obtained by the Pennsylvania P Index (Table 2). We attribute the improved relationship between subcatchment diffuse TP losses and Danish P Index values to the Danish P Index being able to more correctly describe the most important factors that cumulatively determine $\mathrm{P}$ losses to surface waters in Danish catchments. It is, however, important to underline that even though the Danish P Index works well at the catchment scale, we still haven't tested whether the Danish P Index correctly rank the vulnerability of individual fields to $\mathrm{P}$ losses. This is important because the chief purpose of applying a P Index to a catchment is to identify those areas (fields) that contribute the most to total P losses. Thereby cost-effective remedial measures can be targeted.

Figure 1. TP losses (2002) as a function of catchment $P$ Index values calculated by the Danish P Index. Solid line: TP loss $=0.0738^{\star} E X P\left[0.144^{\star}\right.$ catchment P Index], $p<0.0001, R^{2}=0.85$.

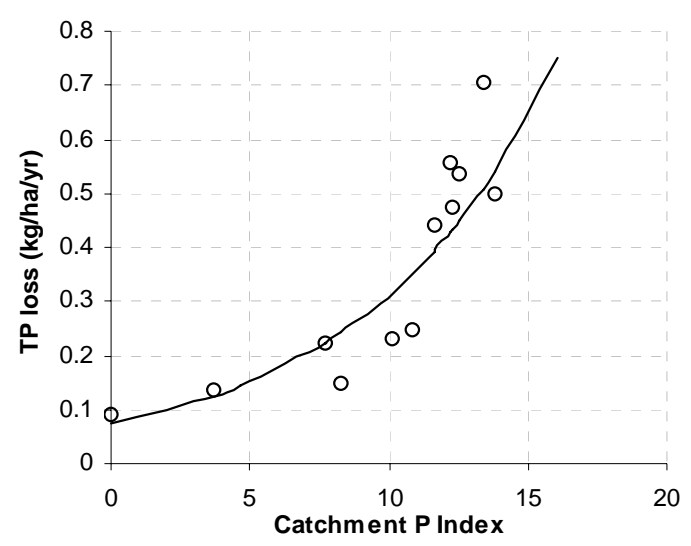

Table 2. Coefficient of determination $\left(R^{2}\right)$ for a linear relationship between catchment $P$ Index values and annual diffuse subcatchment TP losses (transformed by the natural logarithm). The Danish P Index and the Pennsylvania P Index compared.

\begin{tabular}{lll}
\hline & $\mathbf{2 0 0 2}\left(\mathbf{R}^{2}\right)$ & $\mathbf{1 9 9 8} \mathbf{- 2 0 0 2}\left(\mathbf{R}^{2}\right)$ \\
\hline Pennsylvania P Index & 0.65 & 0.68 \\
The Danish P Index & 0.85 & 0.79 \\
\hline
\end{tabular}




\section{References}

Andersen, H.E., Kronvang, B. \& Larsen, S.E. (2004), Development, validation and application of Danish empirical phosphorus models. J. Hydrol., vol. 304, pp. 355-365.

Coale, F.J., Sims, J.T. \& Leytem, A.B. (2002), Accelerated deployment of an agricultural nutrient management tool. The Maryland phosphorus site index. J. Env. Qual., vol. 31, pp. 1471-1476.

Gburek, W.J., Sharpley, A.N.,

Heathwaite, A.L. \& Folmar, G.J. (2000), Phosphorus management at the watershed scale: A modification of the phosphorus index. J. Environ. Qual., vol. 29, pp. 130-144.

Kronvang, B., Grant, R., Laubel, A.R. \& Pedersen, M.L. (2002), Quantifying Sediment and Nutrient Pathways within Danish Agricultural Catchments. In: Haygarth, P.M. \& Jarvis, S.C. (eds.) Agriculture, Hydrology and Water Quality. CABI Publishing, pp. 282-301. Kronvang, B., Laubel, A., Larsen, S.E., Andersen, H.E. \& Djurhuus, J. (2005), Buffer zones as a sink for sediment and phosphorus between the field and stream: Danish field experiences. Water Sci. Tech., vol. 51(3-4), pp. 55-62.
Poulsen, H.D. \& Rubæk, G.H. (eds.) (2005), Fosfor i dansk landbrug. Omsætning, tab og virkemidler mod tab. DIAS report (in prep.). (in Danish). Sharpley, A.N., Kleinman, P.J.A., McDowell, R.W., Gitau, M. \& Bryant, R.B. (2002), Modelling phosphorus transport in agricultural watersheds: Processes and possibilities. J. Soil Water Conser., vol. 57, pp. 425-439.

Sharpley, A.N., Weld, J.L., Beegle, D.B., Kleinman, P.J.A., Gburek, W.L., Moore, P.A. \& Mullins, G. (2003), Development of phosphorus indices for nutrient management planning strategies in the U.S. J. Soil Water Conserv., vol. 58(3), pp. 137-152.

Svendsen, L.M. \& Kronvang, B. (eds.) (1991), Phosphorus in the Nordic contries - methods, bioavailability, effects and measures. NORD: vol. 47, 201 pp. (In Danish with extended English summary).

Uusio-Kämppä, J., Braskerud, B., Jnasson, H., Syversen, N. \& Uusitalo, R. (2000), Buffer zones and constructed wetlands as filters for agricultural phosphorus. J. Env. Qual., vol. 29, pp. 151158. 


\title{
3.10 Incorporating Economics into P Risk Assessment
}

\author{
Anni Huhtala
}

Agrifood Research Finland (MTT), Economic Research, Luutnantintie 13, 00410 Helsinki, Finland, anni.huhtala@mtt.fi

The presentation introduces some basic insights from economic theory to guide the design of agri-environmental policy. I briefly outline certain elementary economic concepts (e.g., environmental externalities, cost efficiency, opportunity costs) and discuss alternative policy instruments available for nutrient control. In particular, I point out severe informational problems related to the regulation of non-point source pollution. I also suggest that it would be worth testing the implementation of a costefficient water protection policy by engaging farmers in a competitive (subsidy) bidding procedure for reductions in their $\mathrm{P}$ index.

Economics is the study of choice and gives us a way of understanding how to make best use of scarce resources such as natural resources, machinery, and labor. Almost all issues of public and private policy involve economics and so do our individual choices. Economics starts with individuals making choices based on self-interest but is primarily interested in how these actions ultimately affect society as a whole. Because of unexpected or unintended consequences of human choice and action, good results do not necessarily follow from good intentions, nor do good intentions necessarily lead to good results.

\section{"Market failures" and government intervention}

Environmental economics explores the issue of market failure, in particular the case of negative environmental externalities. Negative externalities are defined as unintentional side-effects of production and consumption that affect a third party negatively. Air, water, and land pollution are textbook examples. A crucial environmental issue in agriculture is the damage caused by farming practices to the environment in the form of overfertilization. As the farmer's initial goal is to maximize agricultural output (crop yield) by the efficient use of inputs (fertilizers), the social outcome is not necessarily optimal if the side-effect of the input is eutrophication of watercourses, which negatively affects the recreational use of lakes, rivers and seas. As "free" markets will generate excessive (water) pollution and the overuse of environmental services, collective or public intervention is necessary. In the effort to find an optimal government policy, economic analysis designs alternative policy instruments for achieving the desired environmental quality and environmental goals.

\section{Cost efficiency and opportunity cost}

Economic appraisal means examining the effects of a proposed policy to see whether the outcome will be "good" or "bad", and to determine which 
policy measure should be chosen. One type of policy appraisal is cost effectiveness analysis, which considers social costs and benefits in order to find the "cheapest" way of meeting a pre-determined target, for example, reducing phosphorous runoff by $50 \%$ from the current baseline over the next five years. In other words, cost effectiveness is defined as the least cost solution to a specified objective, and a policy is cost effective if maximum abatement is achieved by a given cost. A key concept in economic analysis is opportunity cost. The true economic cost of a resource is the value of that resource in its "next best" use; the opportunity cost is the value foregone by using the resource for one purpose rather than another. A typical example of opportunity cost of regulation is the value of crop yield lost due to set-aside requirements or restrictions on the use of phosphorous fertilizers.

\section{Policy instruments: direct regulation and economic instruments}

Current debate on agri-environmental policy increasingly acknowledges the importance of policy instruments that rely on the economic selfinterests of the actors involved. These include market-based incentives for pollution control, e.g., discharge/"Pigovian” taxes, marginal abatement subsidies, and auctions in which farmers bid for compensation to make some land-use or management change that has a beneficial impact on the environment. The use of these instruments is tied to certain institutional and economic prerequisites and the choice of those ultimately employed depends to a large extent on the specific situation. Experience shows that economic instruments of environmental policy ("price-based" regulation) are usually applied in combination with regulatory instruments ("quantity-based" regulation). Price regulation and quantity regulation are equivalent under certainty and perfect information. However, as will be shown below, nutrient control typically involves problems caused by imperfect information.

\section{The Pigovian tax and environmental subsidies}

One way of achieving a cost-efficient abatement of discharges is to levy a pollutant tax on them. The cost per kilogram of reducing "edge-of-farm" nutrient discharge increases as more discharges are withheld. In other words, marginal abatement costs are increasing. A tax should motivate farms producing discharges to take mitigation measures that are less costly than paying the tax. With many polluters who have different abatement costs, emissions tax can achieve a more efficient outcome, or least-cost abatement, than uniform quantity regulation. (See Figure 1). An efficient outcome requires the marginal cost of treatment to be equal for all polluters. The amount of abatement required will then differ across polluters. In Figure 1, farm 1 reduces discharges by 20 and farm 2 by 50 units. Non-uniform quantity regulation could also achieve a least-cost outcome, but may have high informational requirements. Of course, both 
quantity regulation and Pigovian tax require administration and enforcement, but costs may differ.

Environmental subsidies can take the form of "marginal abatement subsidies”, paid as a fixed amount per unit of reduced pollution. Marginal abatement subsidies function as abatement incentives: a subsidy of $€$ per unit of abatement could have the same effect on a polluter's abatement decisions as a Pigovian tax of $€$ per unit of emissions. (Figure 1) However, marginal abatement subsidies require government funding, or additional tax revenue, while a Pigovian tax can generate revenue.

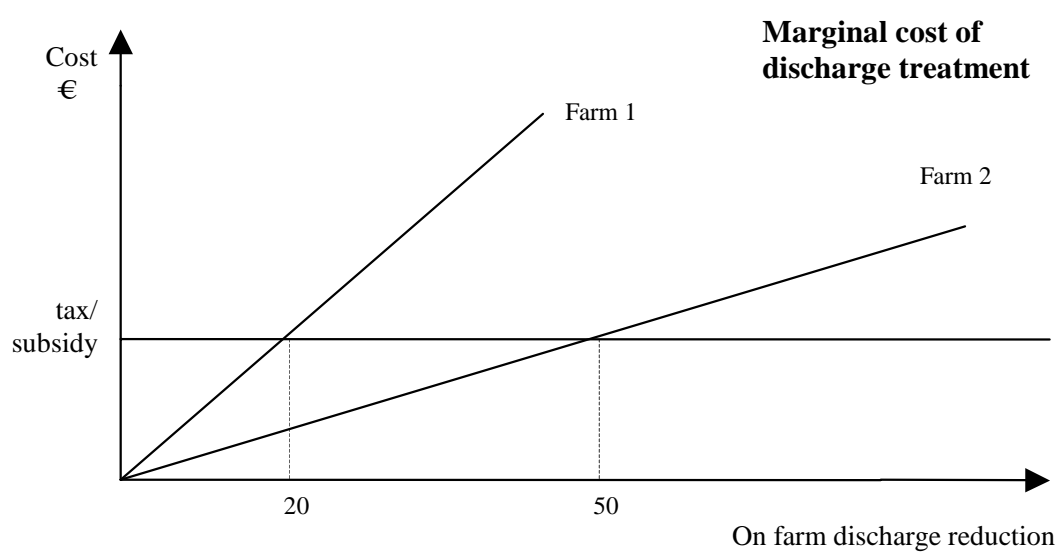

Figure 1. Minimization of treatment costs using market-based instruments: Two sources of discharge (farms 1 and 2) with different abatement costs

\section{Information problems and the choice of policy instrument}

One basic advantage of quantity regulation is that it guarantees a definite level of discharges. With a Pigovian tax or marginal abatement subsidy, the level depends on the polluter's response, which in most cases is unknown to the regulator before implementation of the price-based instrument. Uncertainty concerning a polluter's response to a price-based instrument is the counterpart of a cost-limiting feature: the regulator must weigh the risk of excess pollution against the risk of excess cost when choosing an appropriate level of tax or subsidy. In practice, this may require a process of trial and error, which may prove costly. (Baumol \& Oates, 1971).

Unfortunately, there are other information problems that make it difficult to control non-point source pollution: polluters are difficult to identify; discharges are impossible to monitor; and environmental impacts are uncertain (Braden and Segerson, 1991). The uncertainty regarding environmental damage is often related to the indicator variable used, or the measurement of pollution. Miltz et al (1988) emphasized the importance of pollution dispersion, or transport in nutrient control. Figure 2 demonstrates graphically two farms with identical marginal discharge treatment cost curves. However, their marginal costs of ambient pollution treatment differ, as $20 \%$ and $100 \%$ of the farms' discharges are transported to the 
ambient environment respectively. Figure 2 illustrates that a uniform discharge fee (such as a fertilizer tax) of $€ 100$ per unit of discharge would result in 20 discharge units from each farm, but their total contribution to the ambient concentration would differ: 4 units for farm 1 and 20 units for farm 2. Alternatively, a uniform ambient charge of $€ 125$ per unit of ambient pollution (contribution) would result in the same aggregate ambient pollution (contribution) of 24 units, but farm 1 would reduce its ambient contribution to 8 units and farm 2 to 16 units. Taking into account the transport of discharges, the uniform ambient fee of $€ 125$ would correspond to a differentiated discharge fee of $€ 25$ imposed on farm 1 and $€ 125$ on farm 2. In this case, the differentiated fees would result in least cost abatement and would mean slightly more stringent discharge control on farm 2 and much less discharge control on farm 1.
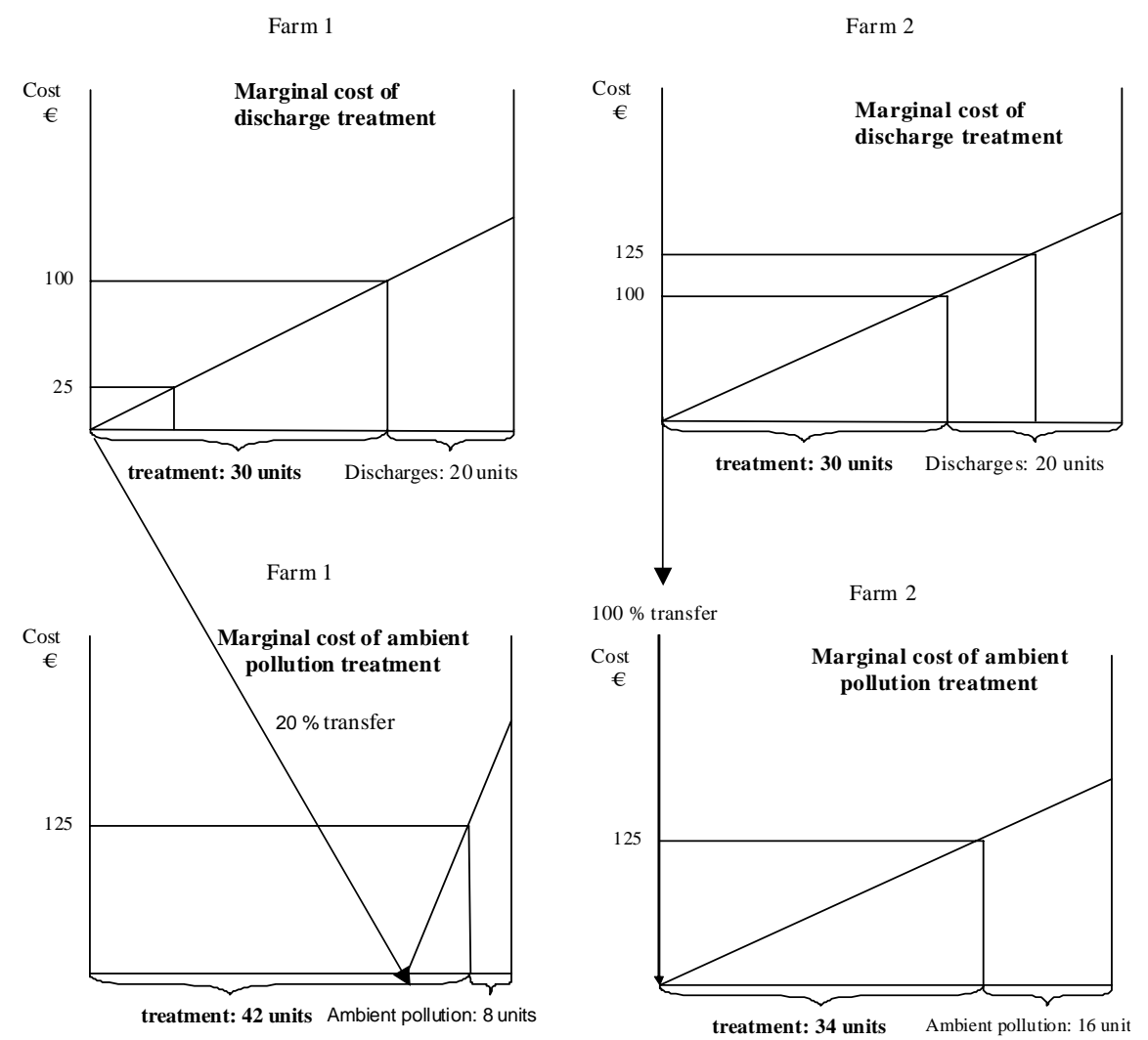

Figure 2. Discharge versus ambient tax/subsidy (adapted from Miltz et al. 1988)

The lesson learned from the analysis of Miltz et al. (1988) is that it may be costly to apply price-based instruments by using indirect indicators of pollution (use of fertilizers), e.g., taxing input use (fertilizer tax), if the factual environmental impacts depend on spatial factors. The more accurate the proxy measure used as environmental indicator, the more efficiently the environmental tax based on the indicator chosen works. Of course, it is an empirical issue how flawed the indicators are in reality 
and how seriously they affect cost efficiency. In fact, a relatively recent Swedish empirical study analyzing the cost efficiency of uniform charges imposed on fertilizers shows that the cost savings from differentiated charges on nitrogen fertilizers would not generate large gains (Brännlund and Gren, 1999).

The analysis in Figure 2 would suggest that ambient pollution taxes should be used instead of discharge taxes but that even the use of ambient taxes can be hampered by possible information problems such as identifying the actual contribution of individual sources. To tackle the problem of uncertainty regarding marginal abatement costs and environmental damage, we need to have an appropriate measure for the pollution impact that is to be regulated. From a policy point of view, the P index could be a good candidate for an improved measure for pollution.

\section{Using the $P$ index and auctions as information-revealing process}

Nutrient control typically involves asymmetric information problems; that is, farmers and government have different information on the possibilities for abatement and degree of environmental damage. Good management decisions on changes in land use for environmental reasons will depend on the provision of information by both private landholders and environmental regulators. Auctions are a policy instrument that can serve this purpose. Auction mechanisms are already used by the USDA to award land management contracts as well as by the US Forest Service to award timber-harvesting contracts on public lands. (Cason et al. 2003, Latacz-Lohmann and Hamsvoort 1998).

For nutrient control, the item to be auctioned could be a unit of abatement as measured by the P index. Instead of giving subsidies for on-farm nutrient management, government would ask how many units of abatement (reduction in the $\mathrm{P}$ index) farmers would offer at any given price (subsidy). The farmers would not be directly regulated but would be free to choose the least-cost abatement measure, or farm management practice that results in a reduction in the $\mathrm{P}$ index (animal waste management, conservation tillage, buffer zone, cover crops, nutrient management etc.). The environmental authority would gain information about the actual marginal abatement cost curve through the responses to the subsidy (bid) level offered. As the hydrological, biophysical and other scientific expertise available to regulators provides them with the best information on the relationship between environmental benefits and farm management practices, a field pilot on nutrient reduction auction would be useful for inducing farmers to learn more about environmental damage and the $\mathrm{P}$ index. In particular, the $\mathrm{P}$ index should be calculated such that two categories could be differentiated: the contribution to the $\mathrm{P}$ index of the farmers' own management practices (e.g. application of phosphorus fertilizers) on the one hand, and of natural random factors over which farmers have no control (e.g. soil hydrologic group) on the other. To start with, informa- 
tion on the $\mathrm{P}$ index values would be gathered from farms by selfreporting, which entails the potential for cheating. However, the incentive to cheat can be checked through more intensive and/or less predictable monitoring and through penalties for misrepresentation and violations. (Polinsky and Shaven, 1979).

It has become evident that the serious informational problems related to non-point source pollution make its control difficult. Ultimately, the potential of using the $\mathrm{P}$ index for cost-efficient nutrient control depends crucially on how well the index succeeds in reflecting the actual environmental damage caused by farming practices.

\section{References}

Baumol, W.J. \& Oates, W.E. (1971), The use of standards and prices for protection of the environment, The Swedish Journal of Economics, vol. 73, pp. 42-54.

Braden, J. \& Segerson, K. (1991), Information problems in the design of nonpoint source pollution policy. Paper presented in the 1991 AERE workshop on "The management of non-point source pollution".

Brännlund, R. \& Gren, I.-M. (1999), Costs of uniform and differentiated charges on a polluting input: An application to nitrogen fertilizers in Sweden. In: Boman et al. (eds.). Topics in environmental economics. Economy \& Environment, vol. 17. Kluwer Academic Publishers, Dordrecht, pp. 33-49.
Cason, T.N., Gangadharan, L. \& Duke, C. (2003), A laboratory study of auctions for reducing non-point source pollution. Journal of Environmental Economics and Management, vol. 46, pp. 446-471.

Latacz-Lohmann, U. \& Hamsvoort, C. Van der (1998), Auctions as a means of creating a market for publiv goods from agriculture. Journal of Agricultural Economics, vol. 49(3). pp. 334-345.

Miltz, D., Braden, J. \& Johnson, G. (1988), Standards versus prices revisited: the case of agricultural non-point source pollution. Journal of Agricultural Economics, vol. 39, pp. 360-368.

Polinsky, A. \& Shavell, S. (1979), The optimal trade-off between the probability and magnitude of fines. American Economic Review, vol. 69, pp. 880-891. 


\title{
3.11 Economic effects of policies to reduce phosphorus from agriculture - a Danish perspective
}

\author{
Berit Hasler and Jørgen Dejgaard Jensen ${ }^{4}$
}

Introduction: The objective of the WFD and the objective of economic analyses

The implementation of the European Water Framework Directive (WFD) requires targeted measures for the control of phosphorus losses from agricultural land to achieve quality goals for surface waters. The Directive also requires measurements of the costs for the agricultural sector and for society, and hereby facilitates the choice of cost-effective solutions.

One of the objectives of calculating costs of different environmental policies to reduce e.g. phosphorus losses from agriculture is to obtain cost-effective or efficient solutions. If a given activity produces a beneficial environmental outcome when applied to a production activity or an area, then it is effective, and if an alternative activity produces a better outcome, it is more effective. Cost-effectiveness is an indicator of the ratio of the costs of providing an activity and the resulting environmental outcome from the activity, e.g. the costs of fulfilling a specified target for reductions of phosphorus losses. If the policy aims at reducing phosphorus losses this ratio can be expressed as DKr or Euro/reduced P loss in kilos or tonnes. Consequently, cost-effectiveness requires use of instruments by which a specified goal is reached by the lowest cost to society. An efficiency analysis will also reveal the most efficient targets from society's point of view by benefit-cost analysis. Benefits of nonmarketed goods can be revealed by valuation techniques and methods, i.e. by asking respondents about their willingness to pay for public goods, e.g. better water quality, or by asking them to choose between alternatives.

This paper only deals with the question of cost-effectiveness. More precisely, it deals with the choice of instruments for cost-effective policy and methods to assess the costs and the effects. As economic research into phosphorus regulation and management is limited in Denmark, it is necessary to consider the research options, and how to utilise the comprehensive non-point source pollution and nitrogen research experience. One conclusion from this research is that instruments for non-point pollution abatement can be divided into general instruments for the national level and specific targeted measures for the regional and local level. Taxes, norms and restrictions can be used as general instruments at the national level, while command and control measures, e.g. required changes in land-use

\footnotetext{
${ }^{4}$ Berit Hasler: National Environmental Research Institute, Denmark, and: Jørgen Dejgaard Jensen: Danish Research Institute of Food Economics, Denmark
} 
(conversion to grass or wetlands, setaside, forestation) or erosion control by buffer strips and zones, can be used in local areas with high risk of losses, or where the recipients are especially sensitive. However, such risk areas have not been designated for phosphorus yet.

Analyses of nitrogen policy instruments further concludes that tax instruments, e.g. an deposit refund system on nitrogen is the most cost effective instrument at the general level because taxes allow the farmers to choose cost effective abatement strategies (Jacobsen et al (2004), Hansen 2002). This analysis also concludes that regional instruments and measures have to be used to implement local objectives.

\section{Instruments for general, national reductions of phosphorus losses from} Danish agriculture

In this section, examples of policy instruments are presented, and preliminary results of the costs of these measures are presented. This is not a full overview over the effects, however. Furthermore, the costeffectiveness ratios are estimated because targets for phosphorus reductions have not yet been formulated. Neither have regional or national targets been set.

General instruments and "handles" for reductions of phosphorus losses at national scale can be seen from figure 1 .

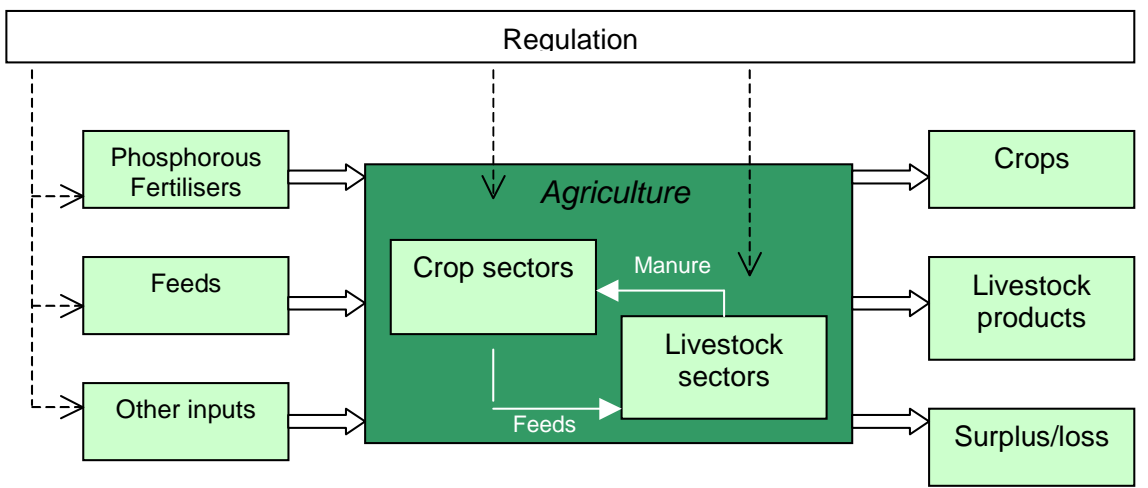

Figure 1. Phosphorus flows and regulation "handles"

As indicated in figure 1, two of the regulation handles with regard to phosphorus represent the input of feeds and fertilisers to agriculture. One possibility is to regulate the total quantity of feeds and/or the composition of feeds, another is to regulate both phosphorus in fodder and fertilisers, while the third is balance requirements or deposit-refund taxes on phosphorus. Such regulation may include economic measures (e.g. a tax on the phosphorus content in specific feeds) or administrative measures (e.g. bans on specific feed components or required standards).

A tax on fodder has been found specifically interesting because this will influence the content of $\mathrm{P}$ in livestock manure, which has been found to be one of the major sources of the phosphorus problem (Jacobsen et al, 2004). A tax on the phosphorus content in specific feed components will 
affect the relative prices of these components, which will provide economic incentives to change the feed composition towards components with lower phosphorus content.

Such economic incentives are often measured in terms of price elasticities. A price elasticity expresses the percentage response in the demand for a given feed component with a one per cent increase in the price of this component. Among other aspects, the change in composition depends on the nutritional requirements of the animals. Price elasticities for seven different feed components have been estimated econometrically using data on aggregate feed use for Denmark (wheat, barley, maize, rape meal, soya meal, sunflower meal, and other concentrates). Of these, grains have a relatively low content of phosphorus, whereas the others exhibit a relatively high P-concentration. A specific tax scheme has been analysed, resulting in a tax of 4 DKK per kg $\mathrm{P}$ on $\mathrm{P}$ exceeding 0.4 per cent in individual feeds ${ }^{5}$. The scheme implies that grains are not taxed at all, because the $\mathrm{P}$ content in grains is below 0.4 per cent. Thus, the tax imposes a shift in relative feed prices, so grains become relatively cheaper. Consequently, the tax increases the share of grains in the feed composition, but decreases the shares of oilseed cakes and other concentrate feeds. Thus, the average concentration of $\mathrm{P}$ in feed decreases due to the tax scheme. However, because the changes in feed composition are rather modest, the effect on the average P concentration is also low - a decrease of $0.06 \mathrm{~kg}$ $\mathrm{P}$ per tonne feed. Key explanations for these quite modest effects are that the proposed tax scheme has only very limited influence on the feed prices but also that the propensity to substitute between feed components seems to be quite moderate. For feed components with a high P content, the price increases by some two percent, and on average, the feed price increases by 0.2 percent.

No certain estimates on the cost and effects exist, but preliminary estimates indicate 2 to $2.5 \mathrm{DKr} / \mathrm{kg}$ P residual reduced (Jacobsen et al, op cit).

Another handle, cf. figure 1, is regulation of the use of other inputs, e.g. a tax on the nitrogen surplus. A tax on nitrogen input may lead to changes in crop composition towards less intensive crops and to reductions in livestock activity levels - effects which may both have positive implications for the phosphorus reduction objective. Analyses have been carried out concerning different tax rates on nitrogen surplus in Denmark, using ESMERALDA (Jabobsen et al, 2004). The results indicate that a tax on nitrogen surplus at $4 \mathrm{DKK} / \mathrm{kg}$ can reduce the P-surplus by around $1 \mathrm{~kg}$ per hectare. There is some regional variation in the reduction.

Regional instruments and measures for phosphorus reductions

Conversion of cropland to permanent grassland with or without subsidy schemes can reduce phosphorus losses because of reduced inputs of $\mathrm{P}$ and because of reductions in erosion from the area. If subsidy schemes are

\footnotetext{
${ }^{5}$ The specific tax scheme was designed as part of an analysis for the Danish Government.
} 
used, this is not very expensive for the farmers, but the costs for society can be high. The costs of conversion to grassland were estimated for nitrogen abatement. Compared to forestation and establishment of wetlands or set-aside, conversion to grassland was not cost-effective. But when phosphorus reduction is the target these ratios and figures are likely to be different.

Reduction of husbandry production is one of the most expensive methods of reducing nitrogen losses. This measure will similarly require very high reductions in $\mathrm{P}$ losses to be cost-effective compared to other measures, e.g. wetland restoration, buffer strips or forestation.

Land use changes, e.g. set-aside, forestation and wetland restoration, will reduce both nitrogen and phosphorus losses, both because of reduced fertilisation and reduced erosion. Set-aside with the use of EU subsidies is cost-effective in a welfare economic context, and also for the agricultural sector, while forestation and wetlands are more costly. Both these methods has side effects because they provide better conditions for nature, however, and these effects can be taken into account as a benefit to society.

\section{Perspectives for model developments for further analyses}

In Denmark the research in effective instruments and measurements for phosphorus reductions and model assessment hereof, is in its early stages, while research on nitrogen has been conducted for more than 15 years. As previously mentioned, some of the experience from the economic part of the nitrogen research can be utilised in the forthcoming research and advisory work with phosphorus regulation and choice of abatement instruments. Both the modelling experience and the comprehensive literature on regulation of non-point pollution, which forms the theoretical background for the models, can be utilised. In this respect, integrated ecological and economic models are relevant. Consequently, phosphorus modelling can be grafted on existing model frameworks that integrate economic and ecological models at national, regional and local level.

Analyses of cost effectiveness as well as welfare economic assessments of costs and benefits for society can be done with integrated economic and ecological modelling and analysis. Environmental and economic effects of agricultural production can be modelled at different geographical scales and levels of aggregation to indicate effects of measures not implemented yet.

General measures and instruments at national level can be assessed by sector model approaches. The sector models, e.g. the Danish sector model ESMERALDA (Jensen et al 2001), can be linked to environmental models, and thus be used for analyses of costs and environmental effects. Wier et al (2001) is an example of such a national and regional analysis, using ESMERALDA linked to an environmental NP-model (nitrogen and phosphorus model), which calculates nutrient loading to the aquatic envi- 
ronment from Danish agricultural sources by determining leaching, retention, ammonia deposition and emissions. The retention coefficients are divided into 48 catchments, thus allowing for regional assessments of the environmental effects. The phosphorus part of the model is not fully developed, and only the nitrogen part has been used.

The ESMERALDA model is an econometric model describing production, input demands, land allocation, livestock density and various economic and environmentally relevant variables on representative Danish farms (approximately 2000). The farms can be aggregated to relevant sector levels (e.g. national, regional, farm type level) using relevant sets of aggregation factors representing the representation of each individual farm type in the considered "population" of farms. The endogenous variables in the model are assumed to be functions of the economic conditions facing the farms, including agricultural prices, economic support schemes, quantitative regulations etc.

Farm-level analysis aggregated to catchment or landcape level can be used for assessments of regional and local instruments and measures. This concept has been widely used in nitrogen policy evaluation (e.g. Vatn et al. 1996, Hasler 1999, Schou et al 2000). The farm-level approach is justified by the fact that production intensity, crop selection, crop rotation, livestock type and fertilisation type and level are all determined at farm level, and the farm-level approach provides detailed data. Nutrient losses can be expressed as a function of crop acreage apportioned by soil type and fertilisation level, and similarly crop yield can be estimated as a function of the same parameters. GIS approaches and aggregation to catchment and landscape levels have to take transactions between farms and exchanges of intermediate products (fodder and manure) into account.

One possibility is to merge the farm level approach with $\mathrm{P}$ index approaches. Johansson \& Randall (2003) have incorporated economics into the phosphorus index method by estimating heterogeneous agricultural net returns across watersheds, and thus used the method to analyse and achieve cost-effective target abatement policies for agricultural phosphorus discharge at catchment level. National level data for phosphorus transport factors, source factors, and net returns were applied, and Johansson \& Randall (2003) found that the potential cost-effectiveness of phosphorus abatement efforts were improved by $50 \%$ when compared with a conventional P index. This method can also be applied to Danish data, so that data on net returns can be obtained at regional level.

\section{Conclusions}

Research in cost-effective solutions to obtain P-reductions is scarce in Denmark, but experience from non-point pollution and nitrogen research can be utilised. Preliminary assessments indicate that a tax on phosphorus in fodder can be used to reduce $\mathrm{P}$ content in livestock manure, but also 
that this instrument will not achieve a large enough reduction of $\mathrm{P}$ losses in risk areas. The $\mathrm{P}$ index method can be used together with economic data and thus the cost effectiveness of regional and local measures can be assessed and the solutions can be improved.

\section{References}

Hansen, L.G. (2001), Modelling the effects of Complex regulatory constraints - the case of Danish Nitrogen regulation. SØM publication no. 45, $38 \mathrm{pp}$.

Hasler, B. (1999), Analysis of environmental policy measures aimed at reducing nitrogen leaching at the farm level. Environmental Pollution, vol. 102, pp. 749-754.

Jacobsen, B., Abiltrup, J., Andersen, M., Christensen, T., Hasler, B., Hussain, Z.B., Huusom, H., Jensen, J.D., Schou, J.S. \& Ørum, J.E. (2004), Omkostninger ved reduktion af næringsoftabet til vandmiljøet. Forberedelse af vandmiljøplan III. Rapport fra Økonomigruppen, Fødevareøkonomisk Institut og Danmarks Miljøundersøgelser.

Jensen, J.D. (2000), ESMERALDA - A Regionalised Econometric Model of the Danish Agricultural Sector Contributed paper presented at the $65^{\text {th }} \mathrm{EAAE}$
Seminar: Agricultural Sector Modelling and Policy Information Systems, Bonn 29-31 marts.

Johansson, R.C. \& Randall, J.R. (2003), Incorporating economics into the phosphorus index: An application to U.S. watersheds. Journal of Soil and Water Conservation, vol. 58(5), pp. 224-231. Schou, J.S., Skop, E. \& Jensen, J.D. (2000), Integrated agri-environmental modelling: A cost-effectiveness analysis of two nitrogen tax instruments in the Vejle Fjord watershed, Denmark. Journal of Environmental Management, vol. 58(3), pp. 199-212.

Wier, M., Hasler, B., Andersen, J.M. \& Jensen, J.D. (2001), Environmental and economic effects of a fall in cereal prices in the EU Internal Market - the Case of Denmark. Environmental and Resource Economics, vol. 20(1), pp. 73-90. 


\title{
3.12 Using phosphorous loss assessment tools in practice
}

\author{
Svein Skøien
}

Landbrukskontoret i Follo (Municipal Agriculture Administration). P.O. Box 183, N-1431 Ås, Norway, Svein.skoien@as.kommune.no

The municipality is responsible for dealing with agricultural matters. Formerly there was an agricultural office in each municipality that was responsible for advisory and administrative matters. Today it is common that several municipalities share their agricultural administrative staff, and the amount of advisory work has been reduced and is now taken care of by the farmers' organisations and the research institutes. "Landbrukskontoret i Follo" is a local agriculture administration which has been given authority by 6 rural municipalities in the district Follo, south of Oslo. The main tasks are to deal with laws and regulations and to follow up on local policies and plans for land-use.

There are several laws and regulations concerning land-use, properties and management practices in agriculture and forestry. The legal authorities are the County Governor, the municipality and the Ministry of Agriculture. Increasingly more of the authority in agricultural matters is placed at the local, municipal level.

The national agricultural policy has been decided by the Parliament. This policy is followed up every year by negotiations between the Ministry of agriculture and the farmers' unions. The result of the negotiation is a set of governmental grants to the farmers. Each farmer has to apply for these grants. Most of the grants have specific environmental aims. The applications are sent to the municipality or the local agricultural administration, which is responsible for checking the information from each farm and for controlling that the grants are used according to the conditions.

The municipality also has authority according to the Planning and Building Act, Pollution Control Act and the Water Resource Act. The local councils approve municipal master plans, which are the most important instrument for regulating the land use in the long term. These acts give the necessary authority to regulate the land use more specifically, for instance in order to protect drinking water from pollution or to take care of the nature resources in a broader sense. The EU water framework directive will be implemented in Norway. This will be done at the local level within the authority given by the aforementioned acts. An important consequence will be the need for a closer co-operation between different sectors, such as agriculture, municipal engineering and area planning.

In the district Follo there are several lakes that are used for drinking water and irrigation. The lakes are important for recreational purposes, such as fishing, rowing and swimming. The district also has a coast line that is much used for bathing, fishing and recreation in the summer. The 
population in the area have a strong interest in the water quality, and the local councils have adopted water management plans with clear goals for improved water quality. The main sources causing eutrophication and poor drinking quality are non-point runoff form agriculture, municipal sewage and private sewage. In addition there are some point sources.

Agriculture is one of the largest contributors to phosphorus loss to lakes and rivers. Our office has an important task in trying to reduce this contribution. To achieve this we must first of all encourage the farmers to take voluntary steps or to change their management practices in a way that conserves soil and losses of nutrients. In some cases it is necessary to oblige the farmer to take certain action to reduce pollution. Such instructions most of course have a legal basis. The Norwegian Agriculture has adopted a quality system that also includes an enviromental plan for each farm. By this the farmers have committed themselves to choose an environmentally sound practice. However, it is often necessary to give specific advice based on local conditions for each farm. The farmers generally get support from governmental grants for investments in pollution and erosion control measures. The yearly area support that is given for all cultivated land is also graded to encourage zero-tillage, planting of buffer zones etc. There are specific regulations and governmental grants to several pollution reducing measures:

\section{Reduced or zero-tillage}

Area support graded according to classification of erosion risk.

\section{Catch crops}

Area support graded according to classification of erosion risk.

Buffer strips along rivers and ditches

5-year contracts with the farmer, grant per ha.

Conversion to permanent ley

On areas with high erosion risk. Contract with the farmer. Grant per ha.

Construction of catch ponds/ artificial wetlands

Grants to support investments.

Construction or repairing of drainage systems for erosion control

Grants to support investments.

Construction or repairing of manure stores or other potential point sources

Grants to support investements. 


\section{Fertilizer planning}

No grants given, but a reduction in area support if the fertilizer plan is lacking.

The municipality is responsible for the environment and has legal authority and economical means. Pollution control measures in agriculture are very important in a district with a large proportion of cultivated land. The general agricultural policy has strong environmental goals, but in a specific area it is necessary to aim more accurately. The economic grants are limited, and they should be used where they are most effective. In this respect a P-index is a valuable tool to assist in the planning of various measures. Run-off from agriculture must also be compared to runoff from other sources in order to make a combined calculation of the phosphorus sources and in order to compare the costs of the measures. A P-index provides a method for quantification.

For some years we have used a simplified P-index to estimate the $\mathrm{P}$ run-off from the agricultural areas in watersheds in our district. We use the following information:

\section{Erosion risk map}

Maps are produced by The Norwegian Institute of Land Inventory. Estimates soil erosion from fields that are ploughed in autumn.

The actual tillage

Information from each farm is available at the office. Uses empirical data for research for soil loss form different tillage systems and crops.

\section{Animal farms}

There are only a few animal farms in the district. We make estimates for each farm.

Buffer zones, catch ponds

Use empirical data from research to estimate the reduction in P-runoff.

\section{Fertilizer planning}

We use available information about soil analyses.

\section{Bio-availability}

The bio-available phosphorus in erosion material and run-off has been evaluated in research.

There are a lot of uncertainties in the data and the estimates, but still we consider it to be a valuable method. The results of the calculation are in reasonable accordance with water analyses in the rivers. As we do the calculations every year, we can show the trends. This documentation is very useful for the decision makers. The calculations are also very useful in the communication with the farmers. 
As a municipal office we do not conduct research. Our task is to achieve political aims and to supervise laws and regulations. We need a simple tool for assessing pollution, which can be used with the input data that are easily available to us. 


\title{
3.13 The agricultural advisor's perspective
}

\author{
Janne Linder
}

Swedish Board of Agriculture, 75186 UPPSALA, janne.linder@sjv.se

\section{Use of phosphorus in Sweden}

Arable land in Sweden originally had a low content of P. Field trials in the middle of the $20^{\text {th }}$ century revealed the potential for increased yields both as a direct effect but also as an effect of improved fertility of the soil. Therefore farmers were advised to increase $\mathrm{P}$ application to reach a P-AL class III, (AL=ammonia lactate extraction). The balance point was replacement $+5 \mathrm{~kg}$ of $\mathrm{P}$ to compensate for P-fixation.

Later, in 1983, the recommendations were evaluated and it was indicated that with new relation in price between fertiliser and grain the application of phosphorus was not optimised anymore. A new balance point was set so that application should replace harvested P. In the long run that will mean a drop in the P-AL class and theoretically also in the fertility.

A high P-content in soils is normally associated with animal manure. Earlier many farmers used both animal manure and P-fertiliser. This has changed a lot for different reasons. One tool that has been used by advisors is the nutrient balance. It has been a good help in order to illustrate the amount of $\mathrm{P}$ in bought feed. The rate of application in 1970 was three times higher than today.

Phosphorus balance for arable land in Sweden 2001, kg/ha

\begin{tabular}{llc}
\hline Input & Chemical fertiliser & 6 \\
& Animal manure & 9 \\
& Sewage sludge & 0,5 \\
& Others & 0,6 \\
Output & Harvested & 14,3 \\
Surplus & & 1,6 \\
\hline
\end{tabular}

(MI 40 SM 0301, SCB 2003)

What are we doing at present?

There is pressure to reduce losses of phosphorus into the environment. Environmental objectives are not clearly defined but the direction is clear.

The application rate is always under discussion as mentioned above. There is a need to investigate and calculate different scenarios in order to find an economical strategy for P-application. This is mainly an economical issue for the farmer with only a small impact on losses. But it is at least a step in the right direction if we could show that it is economical to reduce P-application also on farms without animals. Concerning applica- 
tion rates you can never choose to not make a decision because of lack of information.

In order to avoid accumulation of $\mathrm{P}$ there are rules for animal density. The level is restricted to $22 \mathrm{~kg} \mathrm{P}$ in manure per hectare and year on a farm with animals. Farms with too many animals need to have a contract for spreading at neighbouring farms. Advisors work with crop plans and field records to ensure that manure is evenly and efficiently spread over available land.

There is an economical support for farmers planting riparian buffer strips along rivers and ditches. Wetlands are also supported economically and constructed mainly to reduce nitrogen but will also catch some P.

General advice on how to avoid soil erosion and improve infiltration is given to farmers.

\section{What to be done next?}

The programme to reduce nutrient losses from agriculture has focused on the southern part of Sweden. There is now a campaign going on called "Greppa Näringen”(Grasp the nutrients). The main activity is advisory service to farmers. There are short courses, group meetings and written information but most of the contact is individually given advice on each farm. The service offered is divided into modules. A new module that is to be tested soon is the "Phosphorus strategy module".

\section{What is in a "Phosphorus strategy module"}

The advisor visits the farm to see both documents and the fields. A nutrient balance and a crop plan are used to check if $\mathrm{P}$-application is balanced. The balance is also compared to the soil analysis if available. A map is used to note the conclusions. There might be ways to improve manure handling, in both distribution and application methods.

The farmer and the advisor are supposed to take a short field walk with a map and a checklist to look for or discuss

- Soil types and rainfall

- Rivers and ditches

- Elevation, areas at risk of erosion, soil cultivation

- Pots were there is risk of standing surface water

- Riparian buffer strips

Finally the farmer and the advisor agree upon an action plan.

\section{What kind of tools do we need?}

Looking at the module described above it is obvious that a phosphorus index would be a useful tool for the advisor. In order to get a useful tool there are some "specifications" that have to be met: 
- Transparency. You can never work with a tool that you do not understand. Or you can until you get a question. Then you are lost. A good description is a must.

- Keep it simple rather than exact. It is not so important that it is correct in detail as long as you can show the important factors. The advisor is dealing with a lot of questions and is not likely to spend much time to understand a complex tool.

- Not too simple. It is not very useful if you are not able to show impact of measures that are expected to be of importance.

The problem we are facing when it comes to phosphorus is lack of knowledge. A tool like a P-index puts the focus on the important fields of research and trials. But the tool can never create knowledge, only make knowledge operational. Hopefully some of the gaps will be filled in the near future.

\section{How can we effect a change?}

We would like measures to be taken that will reduce losses of phosphorus. The objectives and the measures are to large extent not fully known. Measures that are not very costly for the farmer are more likely to be accepted. They can be recommended also without full evidence of the efficiency. With other more costly measures the efficiency must be far better known. Advice with a high degree of "convincing power" is needed for such measures. Not only the farmer needs to be convinced. The advisor also has to be convinced that measures taken at least are likely to give the expected results.

If the farmer has to undertake significant measures, there will be a demand for monitoring. Monitoring today is mainly done with models. That is not a sufficient feedback for the farmer. In the long run it is necessary to have measurements from the recipients to show the impact of actions taken. 


\subsection{Using phosphorus loss assessment tools in practice - the agricultural advisor's perspective}

\section{Leif Knudsen and Hans S. Østergaard}

Danish Agricultural Advisory Service, Department of Crop Production, Landscentret, 8200 Aarhus, Denmark, lek@landscentret.dk

Until recently the advice on phosphorus only related to it as a plant nutrient. From the late 90s the discussion of phosphorus as an environmental problem began. The discussion has been very intensive during the last years. The main topics in the discussion have been:

- whether the loss of phosphorus from agriculture has a significant impact of the aquatic environment

- if phosphorus will have a more significant impact in the future if the agricultural practice is not changed

- how the use of phosphorus must be incorporated in the legislation

- how fast such a legislation must be implemented

The loss of phosphorus from Danish soils is very low today with an estimated average of 0.4-0.5 kg P per ha. Compared with crop removal or application of phosphorus this loss is very low, and it means no economical loss for the farmer. This is different from nitrogen $(\mathrm{N})$, where the loss of $\mathrm{N}$ from animal farms typically is above $100 \mathrm{~kg} \mathrm{~N}$ per ha. The problem with phosphorus is that even a small loss can have a significant impact on the aquatic environment.

The content of phosphorus in Danish soils has more than doubled within the last 50 years. Each year some 75,000 soil samples are taken for farmers by the advisory system. On average they contain 4,0 mg Olsen P per $100 \mathrm{~g}$ soil. From a plant nutrition point of view, an Olsen P content of 2-4 mg P per $100 \mathrm{~g}$ soil is the general recommendation. It means that there is no need to increase the amount of Olsen P in Danish soils.

It has been calculated that on a national level there is a surplus application of $\mathrm{P}$ of on average $13 \mathrm{~kg}$ phosphorus per ha per year in Denmark. The surplus expresses the amount of $\mathrm{P}$ that is added to the soil and not removed by crops. This amount of $\mathrm{P}$ will be accumulated in soil. The reason for this surplus application in Denmark, even when the Olsen-P content is that high, is the farmers' economical interests in a large animal production. When the allowed number of animals excretes more $\mathrm{P}$ per ha than can be taken up by the crop, that surplus can accumulate in the soil.

The accumulation of phosphorus in the soil can give a higher loss of $\mathrm{P}$ from the field. It is evident that the loss of $\mathrm{P}$ by associated with erosion will be closely correlated to the content of $\mathrm{P}$ in the soil. It is more a question if and when the loss of $\mathrm{P}$ by leaching will be influenced. A higher $\mathrm{P}$ 
content in the soils gives a higher P-saturation of the soil and it may give a higher leaching. In the discussion it has been claimed that the current practice will lead to a higher P-content, a higher P-saturation and that the leaching of $\mathrm{P}$ will increase significantly in the future. Therefore it is necessary to have a limit of $\mathrm{P}$-application in the legislation that ensures that the application of $\mathrm{P}$ not is larger than the crop removal of $\mathrm{P}$.

If we look at the trend in the average of Olsen-P in Danish soils in the period 1986 to 2003 (Figure 1), we can see that there was an increase from 1987 to 1994 and subsequently a small decrease.

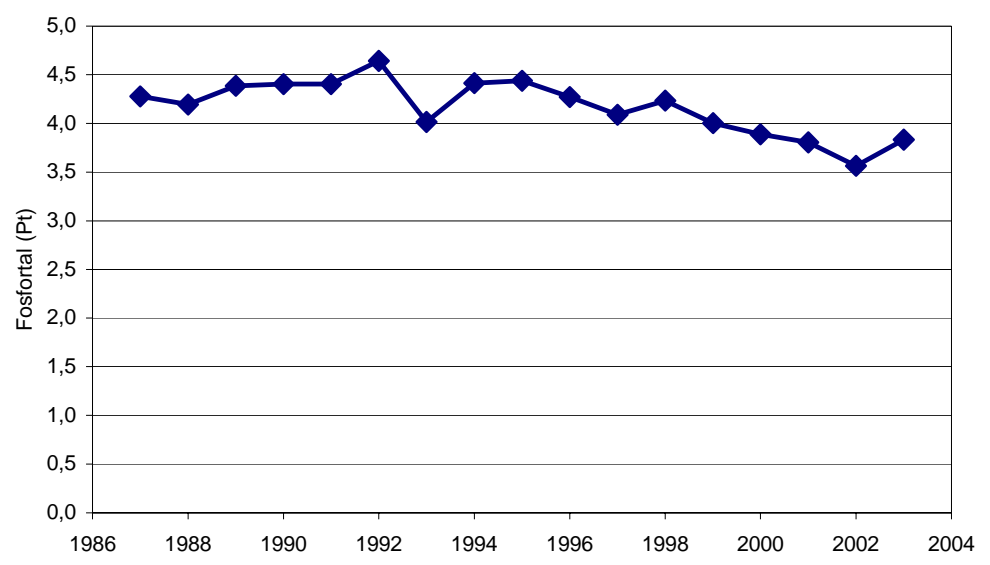

Figure 1. Trend in Olsen-P in Danish soils 1987-2003

In the same period from 1987 to 2003 calculations show that there has been a total surplus of $\mathrm{P}$ applied to the soil of about $100 \mathrm{~kg} P$ per ha. The reason why this has not given an increase in the Olsen-P might be, that it has been bound in non-soluble P-compounds and not extracted as OlsenP. If this is true, the risk of leaching should be reduced in this period and it might in fact be necessary to have a surplus of $\mathrm{P}$ to have an appropriate Olsen-P level in soil.

From the monitoring of P-loss and research activities it is evident that the loss of P differs very much between fields. Most of the total P-loss comes from a small part of the fields. For agriculture it is very important to concentrate restriction to these fields and not to all fields. Therefore it is very important to be able to identify these fields. In the advisory service we have no experience in calculating P-loss from fields. It looks, however, as if the American P-index tested at the Danish Institute of Agricultural Sciences could be a very important tool for this purpose. In the advisory system we would like to be able to do such calculations as soon as it is usable.

Another very important option for agriculture to reduce $P$ losses in the long term is to minimize the excretion of $\mathrm{P}$ from animals. It will be very costly for the farmer to reduce the number of animals per land area. There has already been a very significant reduction in P-excretion in the pig production. However, further reductions are possible by using the enzyme phytase in feed supplements to increase the digestibility of grain phos- 
phorus (Table 1). It ought to be possible to reduce the excretion with 1,4 livestock units per ha to a level, where it is in the same level as crop removal.

Table 1. Phosphorus in feed and pig manure

\begin{tabular}{|c|c|c|c|c|c|}
\hline & \multicolumn{2}{|c|}{ Gram Plfeed unit } & \multicolumn{3}{|c|}{$\begin{array}{l}\mathrm{P} \text { ab animal per } 1,4 \text { livestock } \\
\text { units, } \mathrm{kg} / \mathrm{ha}\end{array}$} \\
\hline & Standard, & Min* & Standard & Min1* & Min2** \\
\hline Sows, incl. piglets to $7 \mathrm{~kg}$ & 5,6 & 4,5 & 40 & 31 & 27 \\
\hline piglets $7-30 \mathrm{~kg}$ & 5,9 & 5,4 & 37 & 31 & 27 \\
\hline growing-finishing pigs $30-102 \mathrm{~kg}$ & 4,9 & 4,1 & 30 & 22 & 20 \\
\hline
\end{tabular}

* Minimum recommendation for total-P in one feed unit.

** Minimum recommendation including $25 \%$ better $\mathrm{P}$ utilization due to phytase supplements 


\title{
3.15 The need for assessment tools, research and cooperation
}

\author{
Ingrid Rydberg
}

Swedish Environmental Protection Agency, S-106 48 Stockholm, Sweden, ingrid.rydberg@naturvardsverket.se

In April 1999 the Swedish Parliament adopted fifteen national environmental quality objectives, describing what quality and state of the environment and the natural and cultural resources of Sweden are ecologically sustainable in the long run. To guide efforts to achieve these objectives each objective has interim targets.

One of the fifteen objectives is "Zero Eutrophication" meaning that: Nutrient levels in soil and water must not be such that they adversely affect human health, the conditions for biological diversity or the possibility of varied use of land and water. This objective is intended to be achieved within one generation.

There are five interim targets for Zero Eutrophication:

1. By 2009 programmes of measures as provided for the EC Water Framework Directive will be established, specifying how good ecological status is to be achieved in lakes, streams and coastal waters.

2. By 2010 Swedish waterborne anthropogenic emissions of phosphorus compounds into lakes, streams and coastal waters will have decreased continuously from 1995 levels.

3. By 2010 Swedish waterborne anthropogenic emissions of nitrogen into the sea areas south of the Åland Sea will have been reduced by at least $30 \%$ compared with the 1995 levels, to 38.500 tonnes

4. By 2010 emissions of ammonia in Sweden will have been reduced by at least $15 \%$ compared with 1995 levels, to 51.700 tonnes.

5. By 2010 emissions of nitrogen oxides to air in Sweden will have been reduced to 148.000 tonnes.

The Swedish EPA is at the moment finishing a report, on request by the government, concerning the target for $\mathrm{P}$, with the mission to specify the target further.

\section{A more specified target for $P$}

The emissions from different sources are estimated by models and by emission statistics. There are several problems with models and incomplete emission statistics, which will be discussed in the presentation. This complicates the wish for a more specified target, a percentage, for further reductions of emissions. 
But the effect of used and proposed measures is also unclear. In order to quantify the factors used in the assessments a better overall understanding of the potential to reduce the losses from the agricultural fields is necessary.

Without research we will not be able to improve our efforts. It is important that society realizes its responsibility to supply funds. But we also need to understand models better (as develop better models) and how results can be used. In all this we need your cooperation. 


\title{
3.16 Using phosphorus loss assessment tools in practise. The river basin manager's perspective
}

\author{
Jørgen Bidstrup \\ County of North Jutland, Jbi@nja.dk
}

Abstract

The Implementation of the Water Framework Directive (WFD) has divided Denmark into 12 river basins. The boundaries of the river basins are almost identical to the County boundaries and the counties are the river basin managers in Denmark.

The overall aim of the WFD is to protect all surface waters and groundwater in the EU within a common approach. The objective is to reach good ecological status for all water bodies by 2015 at the latest.

I have chosen to illustrate the river basin manager perspective with our experiences in Mariager Fjord.

Mariager Fjord is situated at the borderline between the counties of Northern Jutland and Aarhus. The catchment area is $572 \mathrm{~km}^{2}$. Mariager Fjord is $40 \mathrm{~km}$ long. It's a narrow fiord with a deep inner part (30 meter) and a shallow opening to the sea. The morphology of the fiord makes it very sensitive to eutrophication. The land use is like the rest of Denmark dominated by agriculture

Mariager Fjord has a poor environmental quality caused by eutrophication. Since 1983 the two counties have been monitoring the environmental condition of Mariager Fjord according to the National Water Policy Plan and the counties regional plans for environmental quality. The primary goal in the regional plans has been to reduce the emissions from wastewater and fish farms.

Mariager Fjord was in 1997 hit by an extensive, devastating oxygen deficiency. The counties hereafter established a supplementary investigation and modelling program in order to establish a coherent and comprehensive overview of water status within the catchment area.

The objective was to create a River basin management plan according to the WFD. Furthermore, we managed to establish a project under the European Union Interreg program for the North Sea Region. The title is North Sea Regional and Local Implementation of the Water Framework Directive - or in short terms NOLIMP. The project looks at practical ways of implementing the WFD both locally and regionally through pilot projects in five countries.

Good ecological status for Mariager Fjord was based on the morphology and historical data defined as noted in Table 1. 
Table 1

\begin{tabular}{lll}
\hline Ecological status & Objectives & Present status \\
\hline Distribution of eelgrass & Widespread at depths exceeding 2 m & Not widespread \\
Summer transparency & Minimum 4 meters & 2,9 meters \\
Oxygen & More than 4 mg/l to 10 m of depth all year & Not fulfilled \\
\hline
\end{tabular}

Ecological modelling of Mariager Fjord shows that the objectives for good ecological status will be met, if the emission of nitrogen is reduced to 620 tonnes/year and phosphorus is reduced to 16 tonnes/year. To ensure a good ecological status the emission of nitrogen has to be reduced by approximately 130 tonnes/year and phosphorus has to be reduced by approximately 6 tonnes/year beyond the present Danish legislation.

The emission of nitrogen from agriculture accounts for $82 \%$ of the total emission to Mariager Fjord. Because the point sources only account for $5-6 \%$ of the emission, all the possible actions are directed towards the agricultural loss. It is hardly possible to reach the objective without reducing the size of the agricultural area by creating wetlands, plantation of forest, etc.

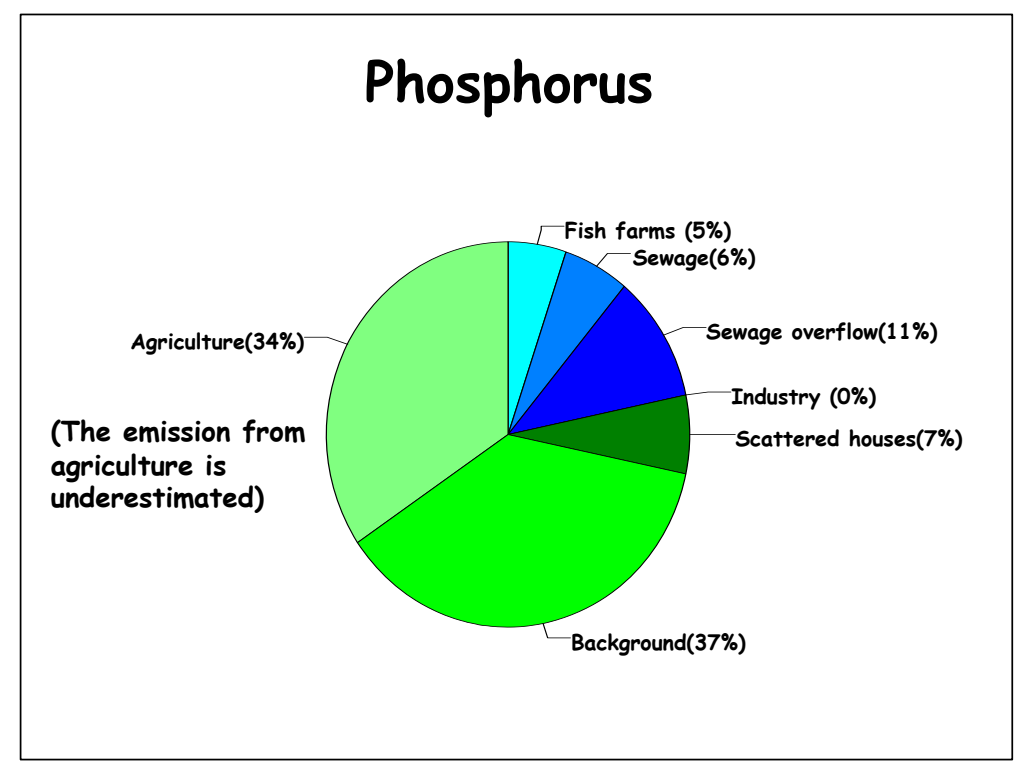

The emission of phosphorus from agriculture accounts for $34 \%$ of the total emission to Mariager Fjord. The emission calculation is based on measurements in 9 streams. We know that our calculation of the total transport of phosphorus is underestimated because of the difficulty in measuring particulate phosphorus. This uncertainty is transferred to the agricultural contribution due to the use of the source appointment method.

The contributions from point sources have been reduced by more than $90 \%$ since 1983 and further reductions will be very expensive. The most 
cost effective action in the catchment area would cost 200,000 Euro and would only reduce the emission by $35 \mathrm{~kg}$ phosphorus yearly.

Phosphorus loss from the agricultural areas to Mariager Fjord is the critical factor controlling the ecological quality.

Agricultural soils in Denmark have a high content of phosphorus. Although the use of $\mathrm{P}$ fertilisers has been reduced, there is still an average P-surplus application of $13.4 \mathrm{~kg} \mathrm{P} / \mathrm{ha}$ due to the large animal production. The surplus application will accumulate in the soil and increase the risk of loss of phosphorus from the fields by erosion and leaching.

The main objective is to ensure a balance between application and removal of phosphorus.

A general balance is on the other hand not sufficient to prevent loss of phosphorus. Many fields in Denmark have a very high content of phosphorus and a negative surplus of phosphorus is recommended.

From the managers point of view, we first of all need knowledge of the sources of diffuse phosphorus losses. Of course we know that erosion is a problem, but there is also a strong indication of leaching of phosphorus and what about application of phosphorus to waterlogged areas and losses due to creating of wetlands.

Nevertheless, we need tools to identify all the different types of the critical source areas and, most importantly, we need the required legislation to implement concrete actions in the catchment area. 



\title{
4. Abstracts of the posters
}

\author{
4.1 Models, phosphorus and practical aspects, what are \\ the relations?
}

Per N. Andersen, Ole Gregor and Carl Erik Bruntze.

Viborg County, Nature, Planning and Highway, Skottenborg 26, P.O. Box 21, DK - 8800

Viborg, Denmark, mtpna@vibamt.dk

\section{Abstract}

Extension of farms have since 1999 been administrated by the counties in Denmark according to the rules of Environmental Impact Assessment (EIA). Leaching of nitrate from agriculture areas has been the main topic in the discussion, in particular protection of groundwater. Many initiatives have been taking to reduce the leaching, e.g. Water Action Plan I and II and now in preparation III. Large efforts have been put into investigations of mechanism and making models of nitrate leaching. Beside this administrative regulations have been made, in particular in areas with special drinking water interest.

Initiatives in regard to phosphorus have until very recently not been taken, the general apprehension have been that phosphorus was a non exciting problem. The retain capacity of the soil will solve the problem in critical areas. Opposite this recent investigations show that the concentration of phosphorus in the soil has increased during the last 15 years. The increase of concentration has coinciding with comparatively increase in livestock densities.

The counties have only in a smaller amount taken initiative to regulate the use of phosphorus. One way of doing so is to point out areas which are considered to be intolerant to a larger amount of phosphorus, e.g. lakes with lobelia or catchments areas to brackish water (Hjarbæk fjord). By doing so all agricultural areas in the specific catchment area have been treated identical. But one may ask is this right the way? In order to be able to differentiate between fields there is a need for a proper index and/or models for leaching of phosphorus.

Opposite to nitrate, models for leaching of phosphorus have been considered, if not impossible then extremely difficult to build. Different attempts have been made, e.g. the Pennsylvania P-index model, RUSLE and WaTem. Two major problems are difficult to handle in the existing models: 1. transport from one field to another. 2. lack of data on region level. 
In the County of Viborg we have taken two different initiatives: 1 . for fields in wetlands and where the distance to watercourses is lesser than $200 \mathrm{~m}$ no additional influence of phosphorus is accepted. 2. trials to build a model using the tools ANUDEM and Tapes G. The poster will show preliminary results and discuss the practical aspect in respect to the administration of farming in Denmark. 


\title{
4.2 A statistical model for estimation of the different contributions to loading
}

\author{
Ämer Bilaletdin, Heikki Kaipainen and Tom Frisk \\ Pirkanmaa Regional Environment Centre, P.O.Box 297, FIN-33101 Tampere, Finland
}

\section{Abstract}

Eutrophication is one of the major environmental problems in inland waters in Finland. The reason for eutrophication is increased nutrient input into waters. In inland waters, phosphorus is often the main limiting nutrient concerning the growth of phytoplankton.

In this study, two mathematical methods for estimating nutrient loading from catchments are discussed. A relatively simple but realistic steady state catchment model was developed in Finland in the beginning of 1990s (Bilaletdin, Koskinen and Frisk, 1991). The idea in this original model is that the nutrient loading can be divided into different sources. A central idea was that only such factors were included in the model that all necessary data can be easily obtained. In the model, the following factors are considered: natural (basic) loading, loading from forestry, loading from sparsely populated areas and cottages, point loading (cities, villages, industry) and agricultural loading.

A new statistical model was developed for assessing total phosphorus and total nitrogen mass flows from a drainage basin (Frisk and Bilaletdin, 2001). The model was developed by taking advantage of geographical information systems (GIS). Special attention is paid to the EU supported agricultural environment protection measures. In the general protection scheme the following factors are crucial: the basic level of fertilization, plant species, storage and use of manure, field edges and filter strips, wintertime land coverage and reduced tillage. In the supplementary scheme, riparian zones, constructed wetlands and sedimentation ponds contribute to the nutrient loading whereas the important of organic farming is obviously small. Tendency to erosion can be taken into account by means of the average slope of the fields and the type of soil. The location of the different loading factors has been taken into account by dividing the drainage basin into zones, and the loading is calculated separately for the different zones using the information about the distance of the zone from the outlet of the basin and the cumulative lake percentage. 


\section{References}

Bilaletdin, Ä, Koskinen, K. \& Frisk, T. (1991), Statistical assessment of different contributions to nutrient loading from a drainage basin. Aqua Fennica, vol. 21, pp. 117-126.
Frisk, T. \& Bilaletdin, Ä. (2001), An integrated model system for the management of lakes and their catchments case study of Lake Längelmävesi, Finland. IAHS, Red Book, vol. 272, pp. 99-106. 


\title{
4.3 Surpluses of phosphorus in Danish agriculture
}

\author{
Tommy Dalgaard, Gitte Rubcek, Jørgen F. Hansen, Arne Kyllingsbcek,
} and Christen Duus Børgesen

Danish Institute of Agricultural Sciences, Department of Agroecology. P.O. Box 50. DK8830 Tjele, Denmark

Based on national import- and export statistics, annual phosphorus surpluses are accounted for Danish Agriculture from 1900 to 2000 A.D. During the whole of the 20th century, more phosphorus is imported than exported and a significant amount of phosphorus has accumulated in the agricultural soils. Aggregated over the century, this accumulated surplus is about 1,4 t phosphorus per ha. In comparison, the measured total phosphorus content in forest soils, which have presumably not been cultivated, is around 2,7 t phosphorus per ha, compared to an average total phosphorus content of around 4,6 t phosphorus per ha agricultural land. During the last 20 years, the annual phosphorus surplus is halved. This is mainly caused by a reduced use of phosphorus in mineral fertilisers, while the amount of phosphorus from animal manures has sustained. The largest phosphorus surplus is found in regions with a high livestock density, and with the continued concentration of livestock production in the western parts of Denmark, the phosphorus surplus has concentrated in these regions. While the loss of phosphorus from agricultural land to the aquatic environment is inferior compared to the phosphorus surplus, the loss is significantly greater than from non-agricultural areas and of environmental concern. On average the loss of phosphorus from agricultural land is about $0,4 \mathrm{~kg}$ per ha compared to around $0,1 \mathrm{~kg}$ phosphorus lost per ha non-agricultural land. With the preparation of the third plan of action for protection of the aquatic environment in Denmark, the handling and use of phosphorus in agriculture will be subject to regulation and measures to protect the aquatic environment will be implemented. A tool to produce regional maps, indicating areas with high phosphorus surpluses is under development. This tool can be used to identify watersheds with large P source potential, and to set up scenarios for solutions to manage and reduce the $\mathrm{P}$ surplus in a watershed. Furthermore it is our intention that this tool in the future can supply GIS maps of P surpluses for P-index based risk assessment tools. 


\title{
4.4 A laboratory method for risk assessment of soil and P-losses
}

\author{
Ararso Etana \\ Department of Soil Sciences, SLU, Sweden, ararso.etana@mv.slu.se
}

Phosphorus losses from arable land occur mainly in a particulate form. Thus, erosion of clay soils is directly related to losses of total P. Tillage and field traffic affect aggregate stability and increase the risk for soil and $\mathrm{P}$ losses by erosion. Types of cation also affect soil aggregate stability. Unstable soil aggregates disperse easily by rain and lost via run-off and/or leaching.

A laboratory investigation was conducted to determine the effects of two tillage systems, namely yearly ploughing and direct drilling, on soil aggregate stability. The same method was also used to investigate clay dispersion of arable land along roads, which were salted during the winter. A turbimetric method, based on the amount of light scattered depending on particle concentration in the suspension, was used to study the aggregate stability.

The results showed that the amount of the scattered light was directly proportional to clay concentration in suspension. Clay dispersion in the samples from ploughed plots was almost double of that from direct drilling. Road salt significantly increased the amount of readily dispersed clay in the soils near the roads. As expected, total $\mathrm{P}$ was higher in suspensions with higher clay concentration but no significant difference was found in the concentration of dissolved P. Thus, turbidimetry can be used to assess the risk for soil and P-losses from arable land under different management systems. 


\title{
4.5 Long-term studies of erosion and phosphorus load under different cultivation methods in three experimental fields in Finland
}

\author{
Minna Kukkonen, Markku Puustinen, Riitta Niinioja, Juha Eskelinen and \\ Eila Turtola ${ }^{6}$
}

The results of long term studies of erosion and phosphorus load under different cultivation methods are compared as a part of the VIHMA project "Management model for runoff water from cultivated areas". The studies were conducted in 3 experimental fields. The fields Aurajoki (A, study period 1990-1994) and Kotkanoja (K, 1980-1999) are located in southwestern Finland with generally mild winters. The Liperi (L, 1990-1999) field lies more north in Eastern Finland, where winters are more arctic (Table 1). For the experiments the fields were divided into plots, where vegetation cover in winter and tillage intensity in autumn varied. The results of runoff, erosion, total phosphorus (TP) and dissolved reactive P (DRP) under different cultivation methods are presented in Table 2.

Table 1. Characteristics of the experimental fields: (A) Aurajoki, (K) Kotkanoja, (L) Liperi

\begin{tabular}{|c|c|c|c|c|c|c|c|c|}
\hline \multirow[t]{2}{*}{ Field } & \multicolumn{2}{|c|}{ Ann. mean in $1971-90$} & \multirow{2}{*}{ Ground frost } & \multirow{2}{*}{$\begin{array}{l}\text { Av. } \\
\text { slope \% }\end{array}$} & \multirow{2}{*}{ Soil type } & \multirow{2}{*}{$\begin{array}{l}\text { P-value* } \\
\text { mg I}^{-1}\end{array}$} & \multicolumn{2}{|l|}{ Runoff } \\
\hline & Temp. ${ }^{\circ} \mathrm{C}$ & Precip. mm & & & & & Surface\% & Subsurf.\% \\
\hline (A) & 5.2 & 698 & occasionally & $7-8$ & clay & 33 & $75-80$ & $20-25$ \\
\hline$(\mathrm{K})$ & 4.3 & 607 & annually & 2 & heavy clay & 5 & $70 / 30 * *$ & $30 / 70^{* *}$ \\
\hline (L) & 2.6 & 643 & annually & $<1$ & heavy clay & 7 & $<5$ & $>95$ \\
\hline
\end{tabular}

* NH4-acet. method; **before/after subsurface drainage improvement in 1991

Table 2. Runoff (mm), and loadings ( $\mathrm{kg} \mathrm{ha}^{-1} \mathrm{yr}^{-1}$, yearly averages) under different cultivation methods: I ploughing in autumn, II stubble, III hay

\begin{tabular}{|c|c|c|c|c|c|c|c|c|c|c|c|c|}
\hline \multirow[t]{2}{*}{ Field } & \multicolumn{3}{|c|}{ Runoff } & \multicolumn{3}{|c|}{ Erosion } & \multicolumn{3}{|l|}{ TP } & \multicolumn{3}{|c|}{ DRP } \\
\hline & $I$ & II & III & $I$ & II & III & $I$ & II & III & $I$ & II & III \\
\hline (A) & 234 & 208 & 209 & 2100 & 790 & 570 & 4.3 & 2.4 & 1.9 & 0.6 & 0.9 & 0.9 \\
\hline (K) & 278 & 276 & 297 & 1180 & 599 & 762 & 1.0 & 0.7 & 1.1 & 0.1 & 0.1 & 0.5 \\
\hline (L) & 420 & 306 & 240 & 134 & 91 & 55 & 1.1 & 0.6 & 0.5 & 0.8 & 0.4 & 0.3 \\
\hline
\end{tabular}

The results show clear differences between the fields and cultivation methods. Erosion and P-loadings were generally highest at (A), where the slope, the soil P-value and the surface water runoff were also highest. Leaching of DRP in relation to TP with all cultivation methods was highest in (L) (58-68\%, other fields 14-49\%). When comparing the different cultivation methods in general, erosion and P-loadings decreased with the

\footnotetext{
6 Minna Kukkonen and Riitta Niinioja: North Karelia Regional Environment Centre, P.O. Box 69, 80101 Joensuu, Finland, Minna.Kukkonen@environment.fi

Markku Puustinen: Finnish Environment Institute, P.O. Box 140, 00251 Helsinki, Finland

Juha Eskelinen and Eila Turtola: Agrifood Research Finland, 31600 Jokioinen, Finland
} 
decreasing slope of the fields and increasing vegetation cover over winter. Climatic differences between the fields affected the runoff. It was generally highest in $(\mathrm{L})$ under all cultivation methods.

\section{References}

Puustinen, M. (2004), The VIHMA

model. In this publication.

Puustinen, M., Koskiaho, J. \& Peltonen, K. (2004), Influence of cultivation methods on suspended solids and phosphorus concentrations in surface runoff on sloped fields. Agriculture, Ecosystems and Environment, vol. 105(4), pp. 565-579.
Turtola, E. (1999), Phosphorus in surface runoff and drainage water affected by cultivation practices. Diss. University of Helsinki. 108 pp.

Turtola, E., Uusitalo, R., Lemola, R., Eskelinen, J. \& Kaseva, A. (2003), P and $\mathrm{N}$ in runoff from a heavy clay soil under reduced tillage. Proceedings of NJF's 22nd Congress Turku, Finland: 358. 


\title{
4.6 Quantification of Phosphorus Losses Through Macroporous Soils with a modified ICECREAM model
}

\author{
Martin H. Larsson, Kristian Persson and Nick Jarvis
}

SLU, Department of Soil Sciences, P.O. Box 7072, SE-75007 Uppsala, Sweden, Martin.Larsson@mv.slu.se

It is well known that losses of phosphorus through macropores can be significant. Despite this, models for quantifying $\mathrm{P}$ transport through soils have been based on the assumption of 'piston flow'. We present here an application with the ICECREAM model (Tattari et al., 2001), which was modified to describe macropore flow.

A simplified dual-porosity concept has now been included in the ICECREAM model to account for the effects of macropore flow. Losses of both dissolved (DRP) and particulate P to tile-drains are described. In this approach, the macropores are considered as a rapid transport pathways without interaction with the micropores. Dissolved P is routed into the macropores at the surface according to the 'mixing depth' concept. Particle generation and detachment at the surface for transport through macropores is treated conceptually different from the original CREAMS erosion calculations and are therefore also separated from those. The model was evaluated by comparing simulation results with field measurements of dissolved and particulate P losses to tile drains for a 2-year period in a structured Swedish clay soil.

After calibration of the macropore flow parameters, the soil particle replenishment and detachability coefficients, and the initial P pools, the model could correctly quantify the total losses and satisfactorily mimic the extremely episodic pattern of P losses at this site (see Fig. 1).

As an example, we also simulated the DRP losses without macropore flow keeping all other parameters constant. Without macropore flow the model underestimates the losses considerably and it was necessary to increase the P-pools in the bottom layer 15 times to achieve realistic losses. We could conclude that without macropore flow there was a weak connection between temporal dynamics of $\mathrm{P}$ amounts at the soil surface and losses through tile-drains. Consequently, without macropore flow it would be difficult to quantify the impact of agricultural management operations on P losses to tile-drains on structured soils. 

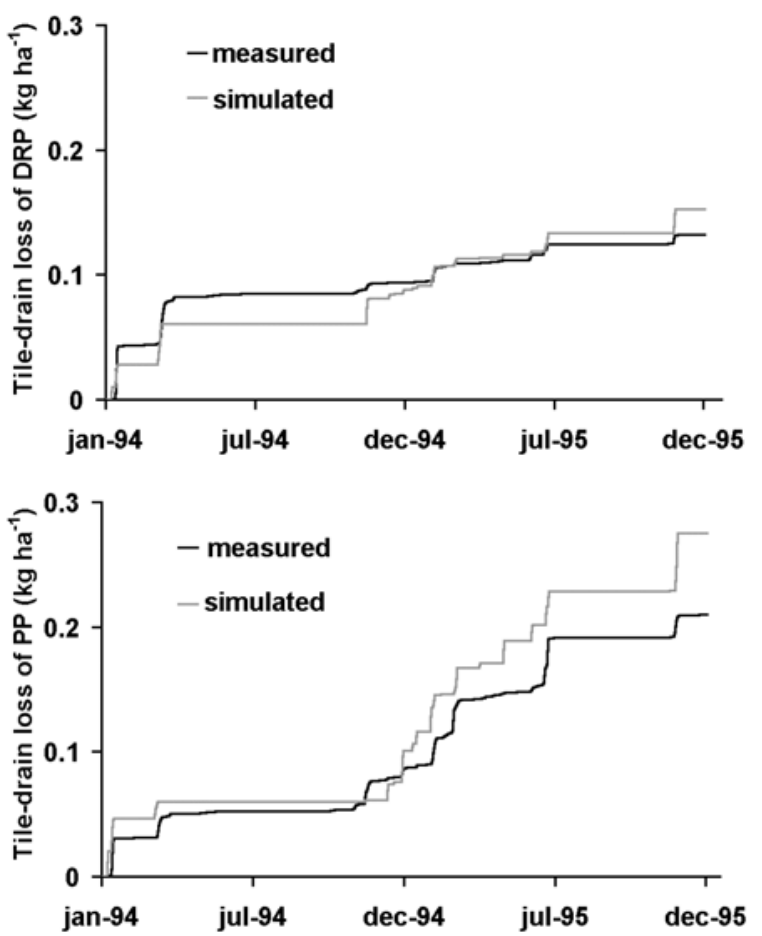

Figure 1. Measured and simulated losses of dissolved (DRP) and particulate phosphorus to tile-drains.

\section{Reference}

Tattari, S., Bärlund, I., Rekolainen, S., Posch, M., Siimes, K., Tuhkanen, H-R. \& Yli-Halla, M. (2001), Modelling sediment yield and phosphorus transport in Finnish clayey soils. Trans. ASAE, vol. 44, pp. 297-307. 


\title{
4.7 Impact of Agriculture Decline on Phosphorus Loads to Lithuanian Rivers
}

\author{
Arvydas Povilaitis
}

Lithuanian University of Agriculture, 4324 Kaunas, Lithuania, arvis@hidro.lzuu.lt

During the last thirteen years Lithuanian agriculture experienced a drastic decline - gross agricultural production on the national scale decreased by $40 \%$, area taken under crops - by $35 \%$, meat production - by $69 \%$. In the same period the quantities of phosphorus fertilizers applied to arable land dropped from 67 to $5 \mathrm{~kg} \mathrm{ha}^{-1}$ per year. Such significant economical recession led to decreasing $\mathrm{P}$ loads in river catchments. One might expect that this should result in a corresponding decrease in riverine loads of $\mathrm{P}$, but did it?

This study analyses the impact of the decline of agriculture on the loads of phosphorus in seventeen Lithuanian rivers during the period from 1991 to 2002. Catchments of the studied rivers are agriculturedominated territories located in different regions of the country. The surface area of the river catchments varies between 194 and $3564 \mathrm{~km}^{2}$.

Water samples were taken at 17 sites once per month and subsequently analyzed for orthophosphate $\left(\mathrm{PO}_{4}-\mathrm{P}\right)$ and total phosphorus $\left(\mathrm{P}_{\mathrm{tot}}\right)$ concentrations. Total phosphorus samples were digested by $\mathrm{K}_{2} \mathrm{~S}_{2} \mathrm{O}_{8}$ to reactive form and analyzed spectrophotometrically by the ammonium molybdate method with ascorbic acid as a reducing agent. Orthophosphate-phosphorus was also analyzed by the ammonium molybdate method. The Partial Mann-Kendall test was applied for detecting statistically significant trends in time series with correction for influencing water discharge.

Despite the drastic decrease of agricultural activity very little evidence was found that the change has influenced riverine concentrations of phosphorus. Only four of the seventeen studied sites showed statistically significant downward trends (one-sided test at the 5\% level) in the total phosphorus and six in the orthophosphate-phosphorus data. It is suggested that the limited response to agriculture decline is related to the substantial inertia of terrestrial ecosystems that control the release of phosphorus from land to rivers as well as to the in-stream physical and biological processes regulating $\mathrm{P}$ fluxes through river systems. 


\title{
4.8 Nutrient balance - phosphorus management tool to minimise its application in a watershed
}

\author{
Ausra Smitiene and Ginutis Kutra \\ Lithuanian University of Agriculture Institute of Water Management, Mituvos str. 9, \\ 50134, Kaunas, Lithuania, ausrac@kaunas.init.lt
}

The highest amount of phosphorus in the soil is in the central part of Lithuania, especially in Kedainiai region: from 1971 to 1990 year the share of arable land with more than $100 \mathrm{mg}_{2} \mathrm{O}_{5} \mathrm{~kg}^{-1}$ in topsoil increased from 23 to $73.6 \%$ there. Application of mineral $\mathrm{P}$ fertilisers was high before 1990s and fertilisation was usually performed not considering soil P content.

The Graisupis river demonstration watershed $\left(14.2 \mathrm{~km}^{2}\right)$ in Kedainiai region has soddy gleic slightly podzolised loam and sandy loam soil and soil $\mathrm{P}$ content is $289 \mathrm{mg} \mathrm{P}_{2} \mathrm{O}_{5} \mathrm{~kg}^{-1}$ on average, determined by AL method. Nutrient balance for demonstration farm in the watershed was calculated in order to show that crops get sufficient amount of $\mathrm{P}$ ( $\mathrm{P}$ balance is positive) and environmental risk is reduced when fertilisation is minimised.

Field experiment performed in the demonstration farm in 1995-1996 years showed that when mineral $P$ fertilisers had not been applied, the amount of $\mathrm{P}$ in $0-50 \mathrm{~cm}$ soil layer was reduced from 742 to $561 \mathrm{kgP} \mathrm{ha}^{-1}$ on one field and from 796 to $570 \mathrm{kgP} \mathrm{ha}^{-1}$ on other field.

In 1996 on the demonstration farm P application (mineral fertilisers and manure) was reduced from 35 to $21 \mathrm{kgP} \mathrm{ha}^{-1}$, then soil P balance changed from +35 to $+16 \mathrm{kgP} \mathrm{ha}^{-1}$. In 1999 application of $\mathrm{P}$ increased up to $71 \mathrm{kgP} \mathrm{ha}^{-1}$ and due to dry weather and low yield, soil P balance was $+52 \mathrm{kgP} \mathrm{ha}{ }^{-1}$. Next three years soil $\mathrm{P}$ balance was negative or close to 0 meaning that the excess phosphorus in soil had been utilised by crops.

Average soil $\mathrm{P}$ balance for all arable land in the watershed did not exceed $\pm 10 \mathrm{kgP} \mathrm{ha}^{-1}$ in 2000-2002 (it was more than $+20 \mathrm{kgP} \mathrm{ha}^{-1}$ before). It means that agricultural companies and other farmers apply proper amount of $\mathrm{P}$ fertilisers.

Average P runoff by the Graisupis river was $0.27 \mathrm{kgP} \mathrm{ha}^{-1}$ and average flow-weighted concentration was $0.17 \mathrm{mgP} \mathrm{l}^{-1}$ in 1996-2003 years. It is known that such concentration might lead to eutrophication of surface water.

Due to information about soil P content and calculation of soil nutrient balance, the application of mineral $\mathrm{P}$ fertilisers is reduced. Now effort should be made on manure management at barns, because they remain the main polluters in agriculture-dominated watersheds (water in subsurface drainage systems has $0.52 \mathrm{mgP} \mathrm{l}^{-1}$ there). 


\title{
4.9 Degree of Phosphorus Saturation for Rapid Risk Assessment of Phosphorus Losses in Southern Sweden
}

\author{
Barbro Ulénand Jan Eriksson ${ }^{7}$
}

\section{Abstract}

Available concentrations of aluminium (Al-AL) and iron (Fe-AL) were determined together with phosphorus (P-AL) in an acid extract of ammonium lactate from 274 topsoil samples from southern Sweden. Sixty of the soils with high $\mathrm{P}$ concentrations and coarse subsoil textures were similarly analysed. A simple phosphorus sorption index (PSI) was quantified together with P-AL for 40 topsoils containing calcium carbonate $\left(\mathrm{CaCO}_{3}\right)$ in the county of Scania. The degree of phosphorus saturation (DPS-AL) calculated from the ratio P-AL / (Al-AL + Fe-AL) on molar basis and the ratio P-AL/ PSI were compared with results from soils from which losses of dissolved reactive phosphate (DRP) through drainage water were measured either in the field or in lysimeter experiments. High frequencies of soils with elevated DPS in the topsoil were found in southeast Sweden in areas of intensive livestock farming (county of Blekinge). However, soil with high DPS and a sandy texture in the subsoil as well as in the topsoil were much less frequent (6\%). In the highland and forest area of south-central Sweden (counties of Kronoberg and Jönköping) soils containing relatively much humus and large amounts of available Al-AL. Thus soils with high risk of $\mathrm{P}$ leaching are probably unusual in this area. Relatively high frequencies (10 \%) of soils with high P-AL/ PSI index values in northwest and south Scania indicate that these soils are prone to $\mathrm{P}$ leaching. In total $4 \%$ of all soils were expected to be problematic based on one of the criteria:

Type 1: Clayey topsoil and DPS-AL value $>30$

Type 2: High DPS-AL topsoil value and a sandy subsoil with DPS-AL value $>30$

Type 3: Calcareous soils with P-AL / PSI value $>6$

\footnotetext{
${ }^{7}$ Barbro Ulén: Division of Water Quality Management, Department of Soil Sciences, Swedish University of Agricultural Sciences, Box 7072, SE-750 07 Uppsala, Sweden. Barbro.Ulen@mv.slu.se Jan Eriksson: Division of Soil Chemistry and Pedology, Department of Soil Sciences, Swedish University of Agricultural Sciences, Box 7014, SE-750 07 Uppsala, Sweden
} 


\subsection{Losses of suspended solids and phosphorus from small agricultural catchments in Norway}

\section{Stine M. Vandsemb and Marianne Bechmann}

Norwegian Centre for Soil and Environmental Research, Jordforsk, Frederik A. Dahlsvei 20, N-1432 Ås, Norway, stine.vandsemb@jordforsk.no

In the development of tools to assess risk of P losses, monitoring data may be used to improve the understanding of $\mathrm{P}$ loss processes and to calibrate the developed tool.

Discharge, nutrient- and soil losses are measured in 8 agricultural dominated catchments in Norway as part of the Norwegian Agricultural Monitoring Program. The poster presents a summary of data on total P losses and losses of suspended solids for the monitoring period including the year 2002-2003.

The total P losses from the cereal dominated catchments varies from 0,5 -2,5 kg/ha. Higher P-losses from one of the cereal dominated catchments, Skuterud than from Mørdre are mainly due to higher runoff. The share of $\mathrm{PO}_{4}-\mathrm{P}$ are lower in cereal dominated catchments than in catchments dominated by grass. Losses of suspended solids from the cereal dominated catchments are reflected in the P-loss level. Small losses suspended solids from the cereal dominated catchment Kolstad is due to high infiltration and thus low surface runoff and erosion.

Higher share of $\mathrm{PO}_{4}-\mathrm{P}$ in grass dominated catchment on organic soil is due to low sorption capacity for P in this soil and high runoff. Lowest Plosses, $350 \mathrm{~g} / \mathrm{ha}$, are measured from Volbu, a low intensively, grass dominated catchment in mid Norway, with annual runoff of ca $300 \mathrm{~mm}$ and low erosion.

Highest P losses, $7 \mathrm{~kg} / \mathrm{ha}$, are measured from the Vasshaglona catchment, dominated by among other vegetables with high $\mathrm{P}$ application level. High P content (P-AL varies from 7-111) and high erosion contribute to the high losses. After harvesting of potatoes and vegetables these areas are prone to erosion processes. Stream bank erosion may also contribute to extensive parts of the total P-losses.

Further analysis of these monitoring data may contribute valuably to the development of $\mathrm{P}$ assessment tools. 

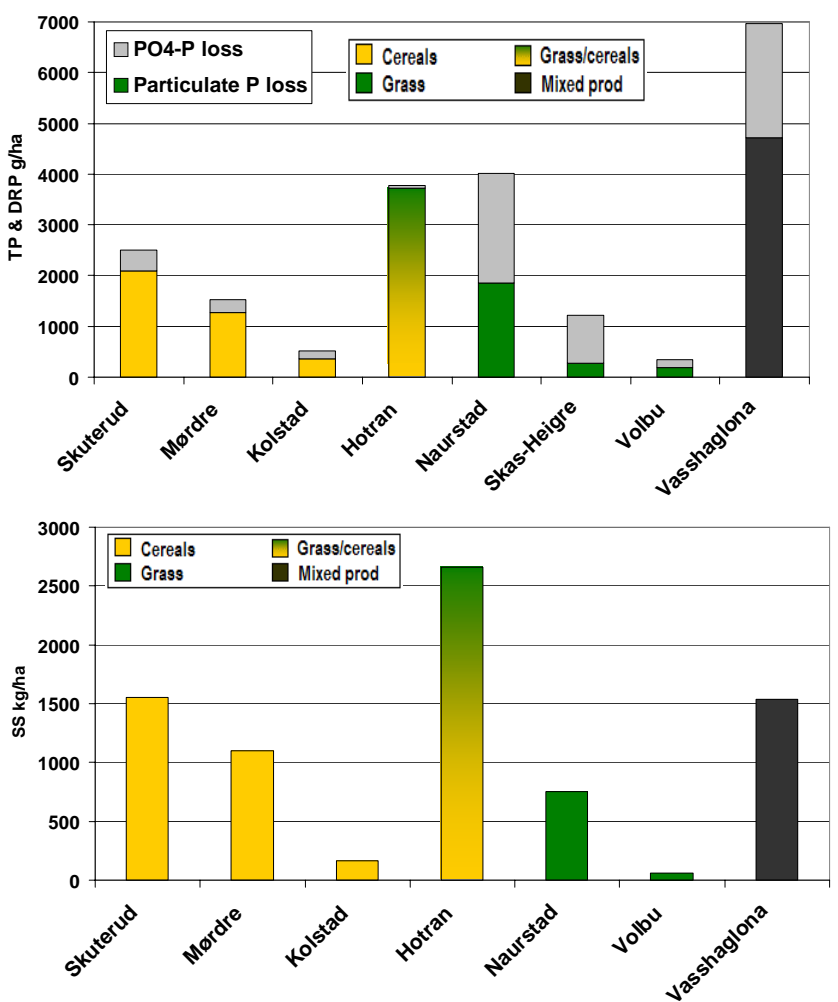

Figure 1. Losses of particulate $\mathrm{P}$ and $\mathrm{PO}_{4}-\mathrm{P}$ (g/ha) (upper fig.) and losses of suspended solids (kg/ha) from agricultural land (lower fig.) for the monitoring period. Colours on bars indicate dominating crop for the catchment.

\section{Reference}

Vandsemb, S.M. et al. (2003), Erosion and nutrient losses from agricultural land. Results from the Norwegian Soil
Monitoring Programme (JOVA)

2002/03. Jordforsk report no. 102/03.

(In Norwegian). 


\subsection{Leaching of phosphorus from Danish sandy soils?}

\section{Lisbeth Wiggers}

Aarhus County, Lyseng Allé 1, 8270 Højbjerg, Denmark, lwn@ag.aaa.dk

Many fields in Denmark receive a surplus of phosphorus due to especially the use of manure. Although the use of fertiliser has been reduced, there is still a surplus of phosphorus input increasing the soil phosphorus status. The regions with the highest stock density and most sandy soil have the highest phosphorus status. Do we expect an increasing transport of dissolved phosphorus to the streams and lakes in the years to come?

In streams without outlet of sewage the concentration of dissolved phosphate is analysed. In sandy catchments the concentration of dissolved phosphorus is higher in streams which do also have high nitrate concentration indicating agricultural influence. In streams in sandy catchments with nitrogen concentration above $5 \mathrm{mg} \mathrm{N} / \mathrm{l}$, the phosphate concentration during winter is 65 ug $\mathrm{P} / \mathrm{l}$ (median). When nitrate concentration is less than $5 \mathrm{mg}$ $\mathrm{N} / \mathrm{l}$ the median phosphate concentration is $18 \mathrm{ug} \mathrm{P} / \mathrm{l}$.

Springs in a sandy catchment do also show a correlation between nitrate and phosphate indicating that phosphate leaching has reached the groundwater feeding the springs.

The correlation between nitrate and phosphate indicate, that the concentration of phosphate is related to agricultural influence.

In 18 streams in agricultural areas (agricultural use $>30 \%$ ) and with no influence of sewage the average concentration (total discharge of phosphate divided by total water discharge) has been calculated for a 6 year period. The mean concentration of phosphate in the more sandy catchments is generally 2-4 times the phosphate concentration in the catchments with low percentage of sand. This indicate an increasing risk of phosphate leaching in sandy catchments - and that leaching already seem to occur from especially more sandy soil. 


\title{
4.12 A systemic analysis for development of cereal growing in organic farming
}

\author{
Hanne W. Carlsen and Tor Arvid Breland ${ }^{8}$
}

In the research programme "Organic cropping systems for higher and more stable cereal yields", the main goal is to achieve new knowledge on systems for sound production of cereals in organic farming with a low stocking rate, as seen in a resource and environmental perspective, and to build up basic competence on the description, analysis and improvement of agroecosystems. One part of the project in this programme is to carry out a systemic analysis for development of cereal cropping in organic farming towards a complex set of partly conflicting goals, among which sustainable management of phosphorus resources is one example.

Losses of nutrients are of major concern in organic farming due to the disappearance of essential nutrients from the agroecosystem and due to eutrofication of the environment. Nitrogen flows need to be investigated because of their yield limiting role and possible harmful environmental effect. Similarly, phosphorus (P) and potassium (K) are key macro nutrients in organic farming because resources are limited and $\mathrm{P}$ has a potentially harmful environmental effect (Askegaard et al., 2003; Løes, 2003). Identification of pools and processes of nutrient dynamics to reduce losses is vital and modelling may be an important tool for assessing the economic viability, agronomic performance, environmental risks and, consequently, to improve nutrient use efficiency in agroecosystems (Blombäck et al., 2003; Öborn et al., 2003). Modelling of nutrient flows is, among other methods, investigated further in this Ph.D.-project.

Changing or improving highly complex agroecosystems (e.g. increasing the grain yields or reducing the phosphorus loss), where artificial fertilisers and chemicals are rejected, calls for an agroecological, systemic research approach involving both socio-economic and ecological objectives (Bell \& Morse, 1999; Olson \& Francis, 1995). In order to improve the overall sustainability of multifunctional agroecosystems including human activity systems, the research needs to begin at the hierarchical level of soft systems methodology because it has the ability, in a structured and conscious way, to work with a system including the human activity systems (Checkland \& Scholes, 1999). Major methodological elements are: 1) Identification and ranking of major goals and issues using a combination of soft and hard systems approaches. 2) Choice of farming system methods to achieve the objectives. 3) Design of theoretical models by linking parameters and farming methods. 4) Evaluation and suggestions on how to improve farming systems.

\footnotetext{
${ }^{8}$ Hanne W. Carlsen: Planteforsk Apelsvoll, N-2849 Kapp, hanne.w.carlsen@planteforsk.no; Tor Arvid Breland: Agric. Univ. of Norway, N-1432 Ås, tor.arvid.breland@ipm.nlh.no
} 


\section{References}

Askegaard, M., Eriksen, J. \& Olesen, J.E. (2003), Exchangeable potassium and potassium balances in organic crop rotations on a coarse sandy soil. Soil Use and Management, vol. 19, pp. 96-103.

Blombäck, K., Eckersten, H., Lewan, E. \& Aronsson, H. (2003), Simulations of soil carbon and nitrogen dynamics during seven years in a catch crop experiment. Agricultural Systems, vol. 76, pp. 95-114.

Bell, S. \& Morse, S. (1999), Sustainability indicators: measuring the immeasurable? Earthscan, London, UK.

Checkland, P. \& Scholes, J. (1999), Soft systems methodology in action. John Wiley \& Sons, Chichester, England.

Løes, A.-K. (2003), Studies of the availability of soil phosphorus (P) and potassium $(\mathrm{K})$ in organic farming systems, and of plant adaptations to low P- and K-availability. Doctor Scientiarum The- sis 2003:29, Dept. of Soil and Water Sciences, Agricultural University of Norway.

Olson, R. \& Francis, C.A. (1995), A hierarchical framework for evaluating diversity in agroecosystems. In: Olson, R., Francis, C.A. \& Kaffka, S. (eds.). Exploring the Role of Diversity in Sustainable Agriculture. American Society of Agronomy, Crop Science Society of America, Soil Science Society of America, Madison, Wisconsin, pp. 5-34.

Öborn, I., Edwards, A.C., Witter, E., Oenema, O., Ivarsson, K., Withers, P.J.A., Nilsson, S.I. \& Stinzing, A.R. (2003), Element balances as a tool for sustainable nutrient management: a critical appraisal of their merits and limitations within an agronomic and environmental context. European Journal of Agronomy, vol. 20, pp. 211-225. 


\title{
5. Programme
}

\author{
Monday 2 February
}

$7.45-8.15 \quad$ Bus picks up from hotels

$8.30-9.00 \quad$ Registration

$9.00-9.30 \quad$ Opening and welcome address

$9.30-10.30$ Impact of agricultural phosphorus on water quality Chair of morning sessions: Ole Hørbye Jacobsen

$\diamond$ What are the WFD's implications for managing agricultural phosphorus?

Seppo Rekolainen, Finnish Environment Institute

$\diamond$ Phosphorus losses in agricultural catchments in the Nordic and Baltic region

Nils Vagstad, Norwegian Institute for Water Research

10.30 - 11.00 Coffee/tea

\subsection{0 - 12.30 Tools for assessing $\mathbf{P}$ loss}

$\diamond$ Strengths and weaknesses of phosphorus models applied to a Norwegian catchment: EUROHARP

Oscar Schoumans, Alterra, The Netherlands

$\diamond \quad$ An Evaluation of Models to Assess the Risk of Phosphorus Loss from Agricultural Land to Water Louise Heathwaite, University of Sheffield, UK

$\diamond \quad$ The $\mathrm{P}$ index: US experience Douglas Beegle, Penn State University, USA

12.30 - 14.00 Lunch

14.00 - 16.00 Experiences with $\mathbf{P}$ index tools in the Nordic countries Chair of afternoon session: Seppo Rekolainen

$\diamond$ Development of a phosphorus index for Norway Marianne Bechmann, Jordforsk, Norway

$\diamond$ Development of a Swedish P index - how far can we reach with the existing knowledge?

Faruk Djodjic, Swedish Univ. of Agricultural Sciences

$\diamond \quad$ The VIHMA model - assessing measures to reduce erosion and P loss in runoff from agricultural land in Finland Markku Puustinen, Finnish Environment Institute

$\diamond$ Modifying, applying and testing a P-index model in Denmark

Hans Estrup Andersen, National Environmental Research Institute, Denmark

16.00 - 16.30 Coffee/tea

16.30 - 17.30 Poster session - risk assessment in practice and mitigation measures

18.00 - Workshop dinner at restaurant Marie Grubbe 


\section{Tuesday 3 February}

$8.00-8.30 \quad$ Bus picks up from hotels

$9.00-10.00$ Socio-economic implications of reducing phosphorus loss from farmland Chair of morning sessions: Louise Heathwaite

$\diamond$ Incorporating economics into P risk assessment Anni Huhtala, Agrifood Research, Finland

$\diamond$ Sector- and welfare-economic effects of policies to reduce phosphorus in Danish agriculture

Berit Hasler, National Environmental Research Institute, Denmark

10.00 - 10.15 Coffee/tea

$10.15-12.15$ Using phosphorus loss assessment tools in practice

$\diamond \quad$ The agricultural advisor's perspective Svein Skøien, Landbrukskontoret Follo, Norway Janne Linder, Swedish Board of Agriculture Leif Knudsen, Danish Agricultural Advisory Service

$\diamond$ The water district manager's perspective Ingrid Rydberg, EPA, Sweden

12.15 - 13.30 Lunch Jørgen Bidstrup, County of Nordjylland, Denmark

$13.30-15.00$ Group work

Participants will be allocated to the different groups on the first workshop day:

$\diamond$ Scope, data availability and quality criteria for building assessment tools (Chair: Louise Heathwaite)

$\diamond \quad$ Calibration of index tools (Chair: Douglas Beegle)

$\diamond$ Ecological relevance of the P index assessments (Chair: Petri Ekholm)

15.00 - 15.30 Coffee/tea

15.30 - 16.30 Synopsis of group work and conclusion

17.00 Transport back to hotels 


\section{Participants}

Henning F. Aaser

County of Ringkjøbing

Damstrædet 2

PO Box 154

6950 Ringkøbing

Denmark

Email: vamhfa@ringamt.dk

Hans Estrup Andersen

National Environmental Research Institute

Vejlsoevej 25

PO Box 314

8600 Silkeborg

Denmark

Phone: 89201400

Email: HEA@DMU.DK

Per Nørmark Andersen

County of Viborg. Dept. Environment

Nature and Planning

Skottenborg 26, PO Box 21

8800 Viborg

Denmark

Phone: + 4587271336

Email: mtpna@vibamt.dk

Marianne Bechmann

Norwegian Centre for Soil and

Environmental Research

1432 Aas

Norway

Email: marianne.bechmann@jordforsk.no

Douglas Beegle

Penn State University

116 ASI Building

16802 University Park, PA

USA

Phone: 814-863-1016

Email: $\underline{\text { dbb@psu.edu }}$

Jørgen Bidstrup

County of Nordjyllands

Niels Bohrsvej 30

9220 Aalborg

Denmark

Phone: 96351415

Email: jbi@nja.dk

Emir Bilaletdin
Pirkanmaa Regional Environment Centre PO Box 297, FIN-33101

Tampere

Finland

Phone: -2419756

Email: emir.bilaletdin@ymparisto.fi

Gitte Blicher-Mathiesen

National Environmental Research Institute

Vejlsøvej 25

PO Box 314

8600 Silkeborg

Denmark

Phone: 89201489

Email: gbm@dmu.dk

Carl Erik Bruntse

County of Viborg. Dept. Environment

Nature and Planning

Skottenborg 26

8800 Viborg

Denmark

Phone: 87271385

Email: mtceb@vibamt.dk

Hanne Weichel Carlsen

The Norwegian Crop Research Institute Apelsvoll

2849 Kapp

Norway

Phone: +47990 44794

Email: hanne.w.carlsen@planteforsk.no

Faruk Djodjic

Swedish University of Agricultural

Sciences

Dept. of Soil Science

PO Box 7072

75007 Uppsala

Sweden

Phone: ++46 18672459

Email: Faruk.Djodjic@mv.slu.se

Petri Ekholm

Finnish Environment Institute

PO Box P.O.Box 140

251 Helsinki

Finland

Phone: 358-9-40300239

Email: petri.ekholm@ymparisto.fi 
Ararso Etana

Swedish University of Agricultural

Sciences

Dept Soil Sciences

PO Box 7014

75007 UPPSALA

Sweden

Phone: +46 18671259

Email: ararso.etana@mv.slu.se

Jørgen F. Hansen

Danish Institute of Agricultural Sciences

Research Centre Foulum

PO Box 50

8830 Tjele

Denmark

Phone: 89991882

Email: jorgenf.hansen@agrsci.dk

Flemming Gertz

County of Ringkjøbing

Damstrædet 2

PO Box 154

6950 Ringkøbing

Denmark

Email:vamfg@ringamt.dk

Birgitte Gjettermann

DHI - Water and Environment

Agern Allé 11

2970 Hørsholm

Denmark

Phone: 45169313

Email: bgj@dhi.dk

Ruth Grant

National Environmental Research Institute

Vejlsøvej 25

PO Box 314

8600 Silbeborg

Denmark

Phone: 89201464

Email: rg@dmu.dk

Kim Hansen

County of Sønderjylland

Jomfrustien 2

6270 Tønder

Denmark

Phone: 74335031

Email: Kim Hansen@sja.dk

Hans Christian Bruun Hansen

The Royal Veterinary and Agricultural University

Dept. of Chemistry, Physics and

Mathematics

Thorvaldsensvej 40
DK-1871 Frederiksberg C

Denmark

Email: haha@kvl.dk

Berit Hasler

National Environmental Research Institute

Frederiksborgvej 399

PO Box P.O. box 358

DK-4000 Roskilde

Denmark

Phone:

Email: $\underline{\text { bh@dmu.dk }}$

Goswin Heckrath

Danish Institute of Agricultural Sciences

Dept. of Agroecology,

P. O. Box 50

DK-8830 Tjele

Denmark

Phone: +45 89991715

Email: Goswin.Heckrath@agrsci.dk

Louise Heathwaite

University of Sheffield

Department of Geography

S10 2TN Sheffield

United Kingdom

Phone: +44 1142227951

Email: a.l.heathwaite@shef.ac.uk

Anni Huhtala

Agrifood Research Finland

Luutnantintie 13

410 Helsinki

Finland

Phone: -56085856

Email: anni.huhtala@mtt.fi

Ole Hørbye Jacobsen

Danish Institute of Agricultural Sciences

Dept. of Agroecology,

PO Box P. O. Box 50

DK-8830 Tjele

Denmark

Phone: +45 89991761

Email: Ole.H.Jacobsen@agrsci.dk

Keld Jessen

County of Ringkjøbing

Damstrædet 2

PO Box 154

6950 Ringkøbing

Denmark

Email: vamkj@ringamt.dk 
Heikki Kaipainen

Pirkanmaa Regional Environment Centre PO Box 297, FIN-33101

Tampere

Finland

Phone: -2419756

Email: heikki.kaipainen@ymparisto.fi

Hans Kjær

Danish Forest and Nature Agency

Haraldsgade 53

København Ø

Denmark

Phone: 39472266

Email: hkj@sns.dk

Charlotte Kjærgaard

Danish Institute of Agricultural Sciences

Foulum

PO Box 50

8830 Tjele

Denmark

Phone: +45 89991864

Email: ‥Kjaergaard@agrsci.dk

Johan Kollerud

Norwegian Agricultural Authority

Stortingsgt 28

PO Box 8140 Dep

33 OSLO

Norway

Phone: + 4724131214

Email: johan.kollerud@slf.dep.no

Annbjørg Kristoffersen

The Norwegian Crop Research Institute, Apelsvoll

2849 KAPP

Norway

Phone: 4761166919

Email: annbjorg.overli@planteforsk.no

Brian Kronvang

National Environmental Research Institute

Vejlsøvej 25

8600 Silkeborg

Denmark

Phone: +45 89201400

Email: bkr@dmu.dk

Poul E. Larsen

ConTerra

Agro Businesspark

Niels Pedersens Allé 2

P.O. Box 10

DK-8830 Tjele

Denmark

Phone: +45 89992541
Email: pla@conterra.dk

Martin Larsson

Swedish University of Agricultural

Sciences

PO Box 7072

SE - 75007 Uppsala

Sweden

Phone: +46 18671169

Email: Martin.Larsson@mv.slu.se

Anker Laubel

County of Vejle

Damhaven

7100 Vejle

Denmark

Email: ala@vejleamt.dk

Janne Linder

Swedish Board of Agriculture

SE-751 86 Uppsala

Sweden

Email: janne.linder@sjv.se

Jakob Magid

The Royal Veterinary and Agricultural

University

Department of Agricultural Sciences

Bülowsvej 17

DK-1870 Frederiksberg C

Denmark

Email: jma@kvl.dk

Hans Jakob Martinsen

DDH

Jens Juuls Vej 18

8260 Viby J

Denmark

Phone: 87386135

Email: hjm@hedeselskabet.dk

Kurt Nielsen

Ministry of the Environment

Dept. of Freshwater Ecology

Vejlsøvej 25

PO Box 314

8600 Silkeborg

Denmark

Phone: 89201400

Email: kni@dmu.dk

Preben Olsen

Danish Institute of Agricultural Sciences

Blichers Alle 1

PO Box 50

8830 Tjele

Denmark

Phone: 89991763 
Email: Preben.Olsen@agrsci.dk

Robert Nøddebo Poulsen

DHI - Water and Environment

Agern Alle 5

2970 Hørsholm

Denmark

Phone: 45169200

Email: rnp@dhi.dk

Arvydas Povilaitis

Lithuanian University of Agriculture

Email: arvis@hidro.lzuu.lt

Markku Puustinen

Finnish Environment Institute

PL 140

FIN-00251 Helsinki

Finland

Email: Markku.Puustinen@ymparisto.fi

Seppo Rekolainen

Finnish Environment Institute

PO Box P.O.Box 140

FIN-00251 Helsinki

Finland

Email: seppo.rekolainen@ymparisto.fi

Gitte Rubæk

Danish Institute of Agricultural Sciences

Research Centre Foulum

PO Box 50

8830 Tjele

Denmark

Phone: 89991859

Email: gitte.rubaek@agrsci.dk

Ingrid Rydberg

Swedish Environmental Protection Agency

Terrestrial Environment Section

Blekholmsterassen 36

S-106 48 Stockholm

Sweden

Phone: + 4686981606

Email:

ingrid.rydberg@naturvardsverket.se

Oscar Schoumans

Alterra

PO Box P.O. Box 47

6700 AA Wageningen

Netherlands

Phone: +31 317474478

Email: oscar.schoumans@wur.nl

Svein Skøien

Landbrukskontoret i Follo

PO Box P.O. Box 183
1421 Ås

Norway

Email: svein.skoien@as.kommune.no

Ausra Smitiene

Lithuanian University of Agriculture

Institute of Water Management

Mituvos 9

50134 Kaunas

Lithuania

Phone: +370 65054299

Email: ausrac@kaunas.init.lt

Anne Gro Thomsen

County of Ringkjøbing

Damstrædet 2

PO Box 154

6950 Ringkøbing

Denmark

Phone: 96753699

Email: tmagt@ringamt.dk

Barbro Ulén

Swedish University of Agricultural

Sciences

Division of Water Quality Management,

PO Box Box 7072

SE 75007 Uppsala

Sweden

Phone: 46018671251

Email: Barbro.Ulen@mv.slu.se

Nils Vagstad

NIVA

PO Box Pb 175 Kjelsås

411 Oslo

Norway

Phone: + 4790754241 / +47 22185102

Email: nils.vagstad@niva.no

Stine Marie Vandsemb

Norwegian Centre for Soil and

Environmental Research

Frederik A. Dahlsvei 20

1430 Ås

Norway

Phone: 4764948100

Email: stine.vandsemb@jordforsk.no

Lisbeth Wiggers

Miljøindsatsafdelingen

Natur og Miljø

Aarhus County

Lyseng Allé 1

DK-8270 Højbjerg

Phone: +45 89446635

Email: lwn@ag.aaa.dk 
Hans Spelling Østergaard Danish Agricultural Advisory Service Udkaersvej 15 8200 Aarhus N
Denmark

Phone: +45 87405431

Email: hso@landscentret.dk 